\title{
RENTABILIDADE DA PRODUÇÃO DE FRANGO DE CORTE SOB CONTRATOS DE INTEGRAÇÃO VERTICAL EM MINAS GERAIS
}

\section{MARIA DA PIEDADE ARAÚJO}

Economista

Orientador: Prof. Dr. Pedro Valentim Marques

Dissertação apresentada à Escola Superior de Agricultura "Luiz de Queiroz", Universidade de São Paulo, para obtenção do título de Mestre em Ciências, Área de Concentração: Economia Aplicada

PIRACICABA

Estado de São Paulo - Brasil

Setembro - 1996 
Dados Internacionais de Catalogação na Publicação (CIP)

DIVISÃO DE BIBLIOTECA E DOCUMENTAÇÃO - Campus "Luiz de Queiroz"/uSP

Araújo, Maria da Piedade

Rentabilidade da produção de frango de corte sob contratos de integraçāo vertical em Minas Gerais / Maria da Piedade Araújo. -- Piracicaba, 1996.

133p.: il.

Dissertação (mestrado) - Escola Superior de Agricultura Luiz de Queiroz, 1996. Bibliografia.

1. Avicultura de Corte - Aspecto economico - Minas Gerais 2. Frango de Corte Produção - Minas Gerais I. Título 


\section{RENTABILIDADE DA PRODUÇÃO DE FRANGO DE CORTE SOB CONTRATOS DE INTEGRAÇÃO VERTICAL EM MINAS GERAIS}

Aprovada em: 04 de novembro de 1996

Comissão Julgadora:

Prof. Dr. Pedro Valentim Marques

ESALQ/USP

Prof. Dr. Geraldo Sant'Ana de Camargo Barros

ESALQ/USP

Dra. Sônia Santana Martins

IEA

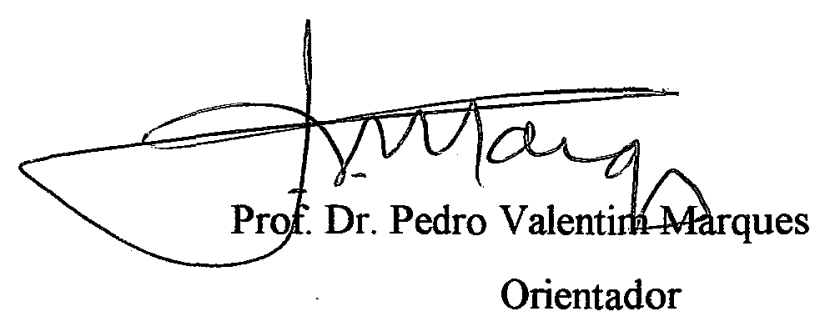




\section{DEDICO}

A Deus, por ter sido sempre a força capaz de fazer vencer a todos os obstáculos.
À minha mãe, Altair Augusta Ferreira e a todos os meus irmãos, que mesmo longe sempre fizeram-se presentes.

A todos os meus sobrinhos, Flávio, Fabiano, Ana Paula, Vinícios, Nathália, Lucas, Ana Cristina, Juliana, Rafael, e ainda os que estão por vir, principalmente meu futuro afilhado. Que o esforço dedicado a elaboração deste trabalho sirva de exemplo a todos vocês.

Ao grande e eterno amigo Eloy Alves Filho, maior incentivador deste trabalho, cuja colaboração e estímulo foram imprescindiveis. 


\section{AGRADECIMENTOS}

À Fundação de Amparo à Pesquisa do Estado de São Paulo - FAPESP, pelo apoio financeiro, indispensável à realização desta pesquisa.

Ao CNPq e FAPESP, pela concessão da bolsa de estudo que tornaram possível a realização do curso de pós-graduação.

À Universidade de São Paulo e à Escola Superior de Agricultura "Luiz de Queiroz", pela oportunidade do aprimoramento acadêmico.

Ao Prof. Dr. Pedro Valentim Marques, pela confiança, apoio e a atenção dispensada durante a orientação deste trabalho.

Ao Prof. Dr. Geraldo Sant'Ana de Camargos Barros, pelas importantes criticas e sugestões apresentadas durante o desenvolvimento da dissertação.

Aos professores Ricardo Shirota e Rodolfo Hoffman, pelas contribuições na parte estatística e econométrica.

À banca examinadora, Prof. Dr. Geraldo Sant'Ana de Barros Camargo e à Dra. Sônia Santana Martins, pelas críticas, comentários e sugestões.

A todos os professores do Departamento de Economia e Sociologia Rural da Esalq, pelos ensinamentos e incentivo durante o curso.

De maneira muito especial à Cláudia, Sílvia e Casimiro, que mais do que amigos, tornaram-se verdadeiros irmãos. Por jamais terem medido esforços diante de um pedido de ajuda, meu sincero e eterno agradecimento.

Ao João, que sempre com a maior presteza e paciência se dispôs a ajudar com seus conhecimentos de informática, meu muito obrigado.

Aos colegas de turma, Marina, Cárliton, Alexandre, Theresa, Ricardo Cotta, Rodrigo, Oswaldo e Jesus, pelo convivio agradável, pela superação de obstáculos, pelo companheirismo e apoio que sempre fizeram presentes nesta jornada, meu muito obrigado.

Ao Robertinho e Patrizia, grandes e eternos amigos, que sempre colocaram à minha disposição seus computadores, que muito facilitaram a elaboração deste trabalho, além da presença constante diante de qualquer eventualidade, meu sincero agradecimento. 
Aos novos e com certeza eternos amigos Ricardo e Cleide, Marco Montoya e Cássia, que também se fizeram presentes nesta jornada, compartilhando dos maus e bons momentos, meu muito obrigado.

À Lú, pelo carinho, atenção, compreensão e grande colaboração que sempre dispensou no atendimento junto à biblioteca, meu eterno agradecimento.

Aos funcionários do Departamento, Maelli, Helenice, Helena, Márcia Corrêa, Márcia Previtalle, Cris e Valdeci, pela atenção incondicional que sempre dispensaram, meu muito obrigado.

Meus agradecimentos ao analista de sistema José Celso C. de Abreu, pelo profissionalismo e paciência que dispensou na elaboração do programa computacional utilizado nesta dissertação.

A José Eugênio Pacelli Lopes, pela grande contribuição e esclarecimentos indispensáveis no início da elaboração deste trabalho.

À Associação de Avicultores de Minas Gerais - AVIMIG, na pessoa da Dra. Marília Martha Ferreira e ao Instituto Mineiro de Agropecuária - IMA, na pessoa da Dra. Vânia Viana Ribeiro, pelas importantes informações e dados indispensáveis à execução deste trabalho.

Às associações de produtores e empresas, que gentilmente cederam as informações, as quais não citamos os nomes.

E a todas as pessoas que de alguma forma contribuiram para a elaboração deste trabalho. 
SUMÁRIO

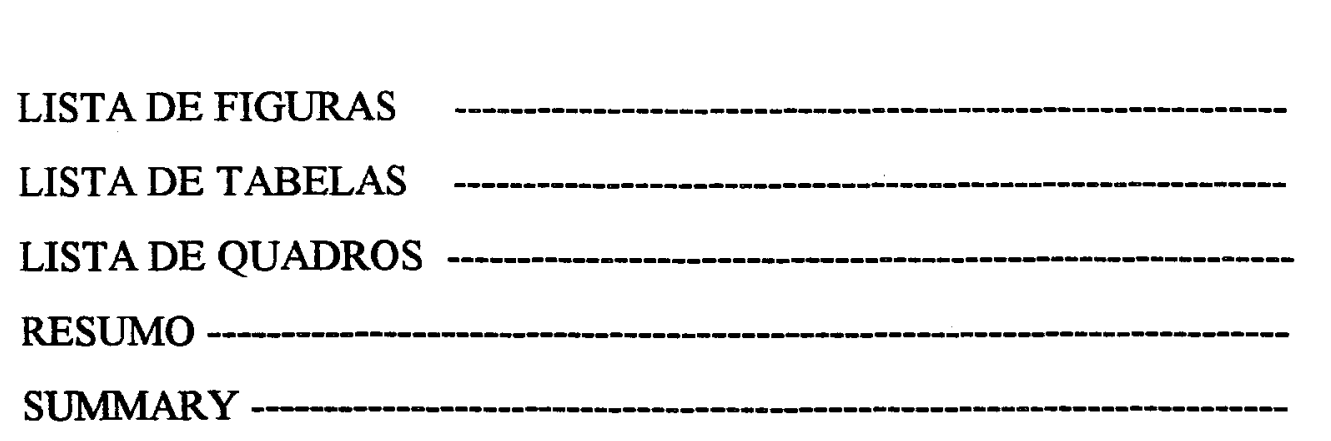

Página

vi

vii

viii

ix

xii

CAPÍTULO I - INTRODUÇÃO

1.1 - Considerações Gerais

1.2 - O Avanço da Produção de Frango de Corte sob Contrato de

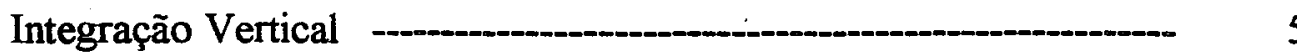

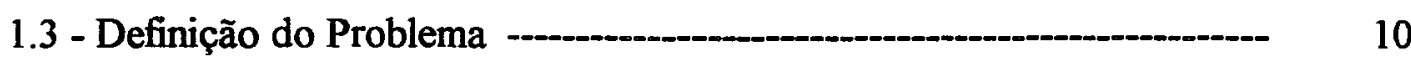

1.4 - Objetivos - ---11

CAPÍTULO II - REFERENCIAL TEÓRICO - METODOLÓGICO ------- 13

2.1 - Integração Vertical sob Contratos

2.1.1 - Sistemas de Remuneração e suas Implicações na Rentabilidade do Investimento

2.2 - Avaliação Econômica de Projetos

2.2.1 - Método de simulação para Análise de Incerteza na Avaliação

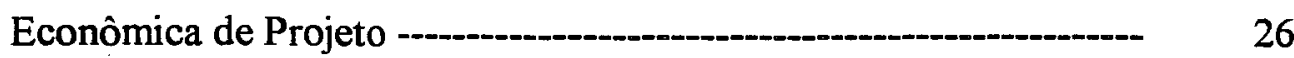

2.2.2 - Identificação da Distribuição de Probabilidade -

2.3 - Procedimento Metodológico e Fonte de Dados ---1-- 30

2.3.1 - Identificação dos Contratos -

2.3.2 - Elaboração do Fluxo de Caixa --_-_-_-_- 31 
2.4 - Custo Médio Ponderado do Capital (CMPC) -

2.5 - O Processo de Simulação - - 36

CAPÍTULO III - RESULTADOS E DISCUSSÕES -

3.1 - A produção sob contratos de integração vertical no Estado de Minas

Gerais - evolução e distribuição geográfica --.--- 47

3.2 - Coordenação Contratual ---on

3.3 - Características dos Contratos de Integração Vertical na Produção de Frango de Corte no Estado de Minas Gerais --.-- 62

3.4 - Análise da Rentabilidade do Investimento - 66

CAPÍTULO IV - RESUMO E CONCLUSÃO - 83

REFERÊNCIAS BIBLIOGRÁFICAS - 89

APÊNDICE 1 -

APÊNDICE 2 - - 2

APÊNDICE 3 - - 116

APÈNDICE 4 -

APÊNDICE 5 - - 120

APÊNDICE 6 - 


\section{LISTA DE FIGURAS}

Figura

Página

1 Descrição Gráfica da Cadeia Produtiva de Frango de Corte -------

2 Função Densidade de Probabilidade de uma Variável Aleatória (X) que segue uma Distribuição Normal

3 Função de Distribuição e a Determinação do valor simulado de uma Variável Aleatória (X), com Distribuição Normal

4a Distribuição de Freqüência e Distribuição de Freqüência Acumulada para Peso Médio (PM)

4b Distribuição de Freqüência e Distribuição de Freqüência Acumulada para Conversão Alimentar

4c Distribuição de Freqüência e Distribuição de Frequuência Acumulada para Índice de Eficiência Produtiva (IEP)

4d Distribuição de Freqüência e Distribuição de Freqüência Acumulada para Fator de Produtividade (FP)

4e Distribuição de Freqüência e Distribuição de Freqüência Acumulada para Pontuação (P)

4f Distribuição de Freqüência e Distribuição de Freqüência

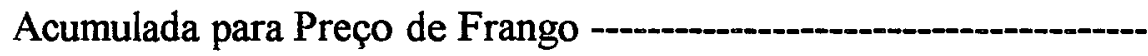

05 Distribuição Regional dos Produtores de Frango de Corte Integrados Contratualmente/Minas Gerais - 1995

06 Função de Densidade e Distribuição de Probabilidade Retangular -- 


\section{LISTA DE TABELAS}

Tabela

Página

1 Distribuição Regional dos Produtores de Frango de Corte Independentes/Cooperados e Integrados Contratualmente/Minas Gerais - 1986/1995

2 Estágios Produtivos em que atuam as Empresas Integradoras Minas Gerais/ 1995

3 Localização Regional, Capacidade de Abate e Inspeção Federal dos Abatedouros de Aves pertencentes às Integradoras - Minas Gerais/1995

4 Motivos que Levaram as Empresas a Integrarem-se com Produtores Avícolas - Minas Gerais/1995

5 Empresas Integradoras - Produção Própria e Integrada de Frango de Corte, Número de Produtores Integrados e Capacidade Média de Alojamento - Minas Gerais/1995

6 Exigências feitas aos Produtores atualmente para Integrarem-se Contratualmente - Minas Gerais/1995

7 Distribuição de Frequêencia das Taxas Internas de Retorno com diferentes valores para a Cama de Frango, a partir dos valores simulados, Contrato A

8 Distribuição de Freqüência das Taxas Internas de Retorno com diferentes valores para a Cama de Frango, a partir dos valores simulados, Contrato B

9 Distribuição de Freqüência das Taxas Internas de Retorno com diferentes valores para a Cama de Frango, a partir dos valores simulados, Contrato $\mathrm{C}$

10 Distribuição de Freqüência das Taxas Internas de Retorno com 
diferentes valores para a Cama de Frango, a partir dos valores simulados, Contrato D 


\section{LISTA DE QUADROS}

Quadro

Página

1 Evolução da Produção, Exportação e Consumo per capita de Frango no Brasil de 1970 a 1995

2 Brasil - Frango de Corte Comercial - Peso Médio, Taxa Média de Conversão Alimentar e Idade Média de Abate - 1930 a 2001 4

3 Modelo Esquemático do Fluxo de Caixa 


\title{
RENTABILIDADE DA PRODUCÃ̃ DE FRANGO DE CORTE SOB CONTRATOS DE INTEGRAÇÃO VERTICAL EM MINAS GERAIS
}

\author{
MARIA DA PIEDADE ARAÚJO \\ Orientador: Prof. Dr. Pedro Valentim Marques
}

Resumo

Nesta pesquisa fez-se o levantamento da participação e distribuição geográfica dos produtores de frango de corte integrados contratualmente no total da produção do Estado de Minas Gerais. Analisou-se também a viabilidade econômica dos contratos de integração vertical, praticados na avicultura de corte daquele Estado sob condições de risco.

Foram analisados quatro contratos, aqui denominados contratos $\mathrm{A}, \mathrm{B}, \mathrm{C} \mathrm{e}$ $\mathrm{D}$, para um galpão padrão de $1.200 \mathrm{~m}^{2}$, com capacidade de alojar até 14.000 aves, utilizando-se como variáveis sujeitas a risco: peso médio, conversão alimentar, ganho de peso diário, mortalidade e preço do quilo do frango vivo cotado pela Associação Paulista de Avicultura (APA), combinadas diferentemente em cada fórmula de remuneração.

Dada a grande importância da cama de frango neste sistema de produção, a avaliação do investimento foi feita com três diferentes valores para a mesma com o objetivo de avaliar a sensibilidade do projeto a variações no valor da cama de frango, considerando o mesmo nível tecnológico.

$\mathrm{Na}$ avaliação econômica, utilizou-se a taxa interna de retorno (TRR) e, para a incorporação da análise de risco, foi empregado o método de simulação de Monte Carlo.

Quanto à representatividade da produção sob coordenação contratual, verificou-se que, apesar de apenas $41,26 \%$ da produção ser conduzida sob este sistema, 
ele agrega 67,32\% dos produtores do Estado. Percebeu-se que existe um consenso quanto à tendência de um aumento da produção sob coordenação contratual.

A produção sob este sistema está concentrada nas regiões da Zona da Mata, Triângulo Mineiro e Centro, com predominância das duas primeiras, agregando $87,24 \%$ do total de produtores integrados.

A análise dos contratos revelou que não existem muitas diferenças nas cláusulas contratuais, a não ser na forma como as empresas determinam o preço a ser pago ao produtor.

Existe um consenso quanto aos motivos que levaram estas empresas a adotarem este sistema de produção, sendo de forma resumida os seguintes: tendência de mercado, padronização das carcaças, matéria prima assegurada e homogênea, redução da necessidade de investimento e gastos operacionais.

As exigências feitas aos produtores ao se integrarem dizem respeito principalmente à distância da granja ao abatedouro e/ou fábrica de ração, bem como galpões devidamente equipados, com exigência mínima de capacidade de alojamento de 6.000 aves, para várias empresas e mínima de 18.000 frangos, para apenas uma delas. Mostra-se com isto a possibilidade de participação de produtores com pequena capacidade de alojamento.

Quanto à análise econômica dos contratos, o processo de simulação revelou taxas internas de retorno variadas, havendo no entanto, nos casos dos contratos B, C e D, uma concentração no intervalo de 16,89 a 19,89\% ao ano, quando avaliados com o valor médio para a cama de frango. Para o caso do contrato $\mathrm{A}$, os resultados concentraram-se no intervalo de 12,5 a $13,5 \%$ ao ano.

Para todos os contratos, o projeto mostrou-se muito sensivel a variações no valor da cama de frango. Feita a simulação tomando-se como nulo o valor da cama de frango, todos os contratos revelaram projetos inviáveis economicamente.

Os resultados da simulação mostraram que mesmo sob condições de risco, e levando-se em consideração apenas o valor médio para a cama de frango, em maior ou menor grau, os contratos garantem aos produtores uma atratividade para o capital 
investido, e que, apesar das diferenças matemáticas das fórmulas de remuneração, em três contratos, a taxa interna de retorno concentrou-se praticamente nos mesmos intervalos. Isto revela que, mesmo utilizando-se de práticas como, por exemplo, pagamento de gás e apanha de frango, nos contratos $\mathrm{B}$ e $\mathrm{C}$ e pagamento do fundo de depreciação, no contrato $\mathrm{D}$, as diferentes fórmulas de remuneração geram praticamente as mesmas taxas internas de retorno. Apenas o contrato A, diferenciou-se significativamente dos demais.

De maneira geral, os resultados revelaram que a viabilidade do investimento independente do contrato e fórmula de remuneração a que estão submetidos os produtores integrados, está intimamente relacionada ao valor que será conseguido pela venda da cama de frango. 


\title{
PROFITABILITY OF POULTRY PRODUCTION UNDER VERTICAL INTEGRATION CONTRACTS IN MINAS GERAIS
}

\author{
Author: MARIA DA PIEDADE ARAÚJO \\ Adviser: Prof. Dr. Pedro Valentim Marques
}

\section{SUMMARY}

This study is concerned about a survey of the share and geographical distribution of integrated poultry farmers through contracts, in relation to the total production in Minas Gerais State. It was examined the economic viability of the vertical integration contracts, under risk conditions, commonly used by poultry sector in this State.

Four different contracts, named A, B, C and D were analysed, for a standard size shed of 1,200 square meters, with lodging capacity of up to 14,000 chickens. The risk variables considered were: average weight, food convertion, daily weight gain, mortality, and the unit price for alive chicken coted by Associação Paulista de Avicultura (APA), combined differently in each rewarding formula.

Because of the poultry manure was of great importance in this production system, the investment evaluation was done using three different values for it, in order to verify the project sensibility to these values changes, taking in account the same technological levels.

Internal rates of return were calculated to the economic evaluation and the risk factor analysis was considered through a Monte Carlo's simulation model.

Data indicated that though $41,26 \%$ of poultry production is conducted under coordination contracts, that means includes over $67,32 \%$ of Minas Gerais total 
farmers. There's a common sense about an increasing trend of production under contractual coordination.

This kind of production system is concentrated in Zona da Mata, Triângulo Mineiro and Center Region, mostly the first and second ones which hold $87,24 \%$ of total integrated producers.

Contracts study doesn't show many differences on clauses, except by the way enterprises calculate the prices that will be paid for their poultry suppliers.

There are many accepted reasons explaining enterprises adoption with this production system such as market trends, carcass standartization, homogeneous and guaranteed supply, investment and operational expenditures reductions.

Conditions generally imposed to farmers by integration process refer to the distance between the farm and the slaughter house and/or the feed factory. Proper equipment in the installations are also required, and so is a minimum lodging capacity of 6,000 chickens for most enterprises and a minimum limit of 18,000 chickens for just one of them. This fact makes clear the viability of small producer's participation on this business.

Simulation process indicate different internal rates of return, with B, C and D contracts rates ranging from $16.89 \%$ to $19.89 \%$ by year, considering the averaged value for poultry manure variable in the analysis. Results were concentrated between $12.5 \%$ and $13.5 \%$ by year, for contract $\mathrm{A}$.

A great sensibility to variations in poultry manure values was verified for all the contracts. When that value was null, the simulation has shown economic inviability for all the cases in the scope of this study.

Simulation outputs indicated that under risk conditions and taking in account just an average value for poultry manure, the contracts provide attractiveness for farmers invested capital, and that besides the existing mathematical differences on the rewarding formulae, internal rates of return for three of the contracts were concentrated almost in the same range of variation. 
This shows that different rewarding formulae generates basically the same internal rates of return although companies adopt measures like gas payment and poultry harvesting under $\mathrm{B}$ and $\mathrm{C}$ contracts, or depreciation fund payment under $\mathrm{D}$ contract. Only A contract differed signifcantly from the others.

In general, the results revealed that the investment viability, independently from the kind of contract and rewarding formulae to which integrated farmers are subjected, is closely related to the value they get with the manure poultry sale. 


\section{CAPÍTULO I - INTRODUÇÃo}

\section{1 - Considerações gerais}

A avicultura de corte no Brasil vem se constituindo, desde a década de 60 , numa atividade empresarial caracterizada por crescente avanço tecnológico, apresentando um dos maiores aumentos de produção e produtividade dentro do setor agropecuário (Zirlis et al., 1990). A indústria avícola pode ser considerada uma atividade econòmica internacionalizada e uniforme, não existindo nos tempos atuais fronteiras geográficas de tecnologia, devido ao alto controle do processo biológico, realizado em condições quase artificiais, permitindo que a transferência de tecnologia seja realizada sem maiores dificuldades.

Esse processo de modernização no modo de produção avicola que substituiu a forma tradicional de produzir frangos, iniciou-se segundo Sorj et al. (1982) com a criação do programa de galpões de mil frangos e instalação no Brasil, a partir de 1963, de filiais de empresas americanas, que trouxeram linhagens de avós para produzir internamente matrizes. Estas mudanças propiciaram um crescimento rápido da produção, tornando a carne de frango importante ingrediente da alimentação do brasileiro. Em 1970, o Brasil produziu apenas 217 mil toneladas de carne de frango, passando para mais de 4 milhões de toneladas, em 1995, mostrando que a indústria no período de 25 anos cresceu mais de $1760 \%$ (Quadro 1), com uma taxa média de crescimento anual de, aproximadamente, $12,42 \%$. Pelo mesmo quadro, observa-se que o consumo per capita passou de 2,3 para $23,0 \mathrm{~kg} / \mathrm{hab}$./ano, que, mesmo com crescimento de $900 \%$ no periodo, ainda é baixo quando comparado a paises como Hong Kong, lsrael, Singapura, Estados Unidos e Arábia Saudita. Nesses países o consumo per capita foi respectivamente 35,8, 
33,34, 32,91, 31,34 e 30,66 kg/hab. no ano de 1993 (Aves \& Ovos, 1995). Pode-se dizer que ainda existe muito espaço para crescimento do consumo no Brasil.

QUADRO 1- Evolução da produção, exportação e consumo per capita de frango no Brasil de 1970 a 1995

\begin{tabular}{|c|c|c|c|c|c|c|}
\hline Ano & $\begin{array}{l}\text { Produção (t) } \\
\text { (1) }\end{array}$ & Índice & $\begin{array}{c}\text { Exportação } \\
\text { (t) } \\
\text { (2) }\end{array}$ & $\begin{array}{l}\text { Participação } \\
\text { Percentual de } \\
\text { (2) em (1) }\end{array}$ & $\begin{array}{c}\text { Consumo per } \\
\text { capita } \\
\mathrm{kg} / \mathrm{hab} / \mathrm{ano}(3)\end{array}$ & Índice \\
\hline 1970 & 217000,00 & 100,00 & - & - & 2,3 & 100,00 \\
\hline 1971 & 224000,00 & 103,22 & - & - & 2,4 & 104,38 \\
\hline 1972 & 294000,00 & 135,48 & - & - & 3,0 & 130,43 \\
\hline 1973 & 401000,00 & 184,79 & - & - & 4,0 & 173,91 \\
\hline 1974 & 484000,00 & 223,04 & - & - & 4,7 & 204,35 \\
\hline 1975 & 519000,00 & 239,17 & $3.469,00$ & 0,66 & 4,9 & 213,04 \\
\hline 1976 & 604000,00 & 278,34 & $19.639,00$ & 3,25 & 5,4 & 234,78 \\
\hline 1977 & 698000,00 & 321,59 & $32.829,00$ & 4,70 & 6,0 & 260,87 \\
\hline 1978 & 858000,00 & 395,39 & $50.805,00$ & 5,92 & 7,1 & 308,70 \\
\hline 1979 & 1096000,00 & 505,06 & $81.096,00$ & 7,40 & 8,7 & 378,26 \\
\hline 1980 & 1200000,00 & 552,99 & $165.000,00$ & 13,75 & 8,9 & 386,96 \\
\hline 1981 & 1444000,00 & 665,43 & $293.933,00$ & 20,36 & 8,9 & 386,96 \\
\hline 1982 & 1507000,53 & 694,47 & $301.793,00$ & 20,03 & 8,5 & 369,56 \\
\hline 1983 & 1489000,36 & 686,17 & $289.301,00$ & 19,43 & 9,3 & 404,35 \\
\hline 1984 & 1355000,91 & 624,42 & $280.284,00$ & 20,69 & 8,1 & 352,17 \\
\hline 1985 & 1482000,51 & 682,94 & $269.009,00$ & 18,15 & 8,9 & 386,95 \\
\hline 1986 & 1617000,32 & 745,16 & $224.651,00$ & 13,89 & 10,0 & 434,78 \\
\hline 1987 & 1969000,84 & 907,37 & $214.483,00$ & 10,89 & 12,4 & 539,13 \\
\hline 1988 & 1947000,19 & 897,23 & $241.782,00$ & 12,42 & 11,8 & 513,04 \\
\hline 1989 & 1982000,64 & 913,36 & $243.981,00$ & 12,31 & 12,4 & 539,13 \\
\hline 1990 & 2355000,54 & 1085,25 & $299.218,00$ & 12,71 & 13,4 & 582,61 \\
\hline 1991 & 2627000,74 & 1210,59 & $321.754,00$ & 12,25 & 15,0 & 652,17 \\
\hline 1992 & 2872000,25 & 1323,50 & $370.937,00$ & 12,92 & 16,0 & 695,65 \\
\hline 1993 & 3144000,12 & 1448,84 & $416.952,00$ & 13,26 & 17,0 & 739,13 \\
\hline 1994 & 3411030,00 & 1571,90 & $470.000,00$ & 13,78 & 18,0 & 782,61 \\
\hline 1995 & 4050450,00 & 1866,56 & $510.000,00$ & 12,59 & 23,0 & 1000,00 \\
\hline
\end{tabular}

Fonte: Aves \& Ovos, 1996. 
A avicultura moderna, em sentido mais amplo, é um grande complexo industrial que não pode ser apenas analisado sob a ótica da produção e distribuição. $\mathrm{O}$ complexo avícola compreende também a indústria de ração, produtos veterinários, equipamentos, embalagens e processamento industrial, podendo ser considerado um dos melhores exemplos de integração e interdependência econômica em uma agricultura de mercado ( Zirlis et al., 1990).

O desenvolvimento alcançado pela avicultura de corte nas últimas décadas tem proporcionado o aumento de sua participação no setor agropecuário, não só pela geração de renda, mas também pelo abastecimento, uma vez que a carne de frango representou em 1994, 33,5\% do total de proteinas de origem animal consumidas no Brasil (Aves \& Ovos, 1995). Apesar de seu dinamismo estar no mercado interno, que consome entre 85 a $90 \%$ da produção, não se deve deixar de mencionar que a exportação de carne de frango tem propiciado ao pais participação crescente no comércio internacional, situando-se entre os maiores exportadores, perdendo apenas para os Estados Unidos e França.

Um dos principais fatores responsáveis por este desempenho foi a rápida absorção dos avanços tecnológicos alcançados pelos paises de avicultura desenvolvida, por meio da importação de linhagens de alta produtividade que, aliada ao manejo adequado, permitiu alcançar melhor conversão alimentar e maior ganho de peso diário, diminuindo significativamente o periodo de engorda das aves Zirlis et al. (1990), como é possivel visualizar a partir do Quadro 2. De acordo com Lopes (1992), este desempenho coloca a avicultura brasileira como uma das mais desenvolvidas do mundo, tornando-se dificil o convivio de produtores e processadores comerciais que não se adaptem aos padrões técnicos praticados no mercado mundial.

Apesar desta considerável evolução e, embora a produção avicola esteja disseminada no país, a avicultura industrial não é uma caracteristica do Brasil como um todo, estando boa parte de sua produção concentrada nas regiões Sul e Sudeste, predominando no Sul grandes empresas agroindustriais, dedicando-se principalmente ao mercado exportador. Das 20 empresas que exportaram carne de frango em 1994, as cinco 
primeiras foram responsáveis por $68,62 \%$ do total da exportação, sendo por ordem de importância Sadia Concordia (23\%), Perdigão SC (14,09\%), Ceval (13,29\%), Frangosul $(9,22 \%)$ e Chapecó (9,02\%), mostrando a primazia dos Estados do Sul (Aves \& Ovos, 1995).

QUADRO 2 - Brasil - Frango de corte comercial - peso médio, taxa média de conversão alimentar e idade média de abate - 1930 a 2001

\begin{tabular}{|lccc|}
\hline Ano & $\begin{array}{c}\text { Peso Médio ao Abate } \\
(\mathrm{kg})\end{array}$ & $\begin{array}{c}\text { Taxa Média de Conversão } \\
\text { Alimentar } \\
\text { (kg de ração/kg de peso vivo) }\end{array}$ & $\begin{array}{c}\text { Idade Média de Abate } \\
\text { (dias) }\end{array}$ \\
\hline 1930 & 1,500 & 3,50 & 105 \\
1940 & 1,550 & 3,00 & 98 \\
1950 & 1,800 & 2,50 & 70 \\
1960 & 1,600 & 2,25 & 56 \\
1970 & 1,800 & 2,00 & 49 \\
1980 & 1,700 & 2,00 & 49 \\
1984 & 1,860 & 1,98 & 45 \\
1989 & 1,940 & 1,96 & 45 \\
$2001^{*}$ & 2,240 & 1,78 & 41 \\
\hline
\end{tabular}

* Previsão

Fonte: Aves \& Ovos , 1995.

Minas Gerais já foi o segundo maior Estado produtor de frango de corte do Brasil, perdendo posição para Santa Catarina em meados da década de 70 , e posteriormente para o Rio Grande do Sul e Paraná. Segundo Sorj et al. (1982), esta superação foi propiciada principalmente pela crescente utilização do sistema de produção integrada nesses Estados. No entanto, a produção de frango de corte ainda destaca-se estrategicamente, estando o Estado de Minas Gerais entre os cinco maiores produtores do país de acordo com o Anuário Estatístico do Brasil, 1993, além de ser responsável por, aproximadamente, $60 \%$ das matrizes de corte produzidas no país. 
Em 1994 três empresas mineiras destacaram-se entre as 25 maiores de abate de aves no Brasil: a Dagranja ocupou a $8^{\underline{a}}$ posição, a Pif-Paf a $12^{\underline{a}}$ e a Francap 19a produzindo as duas primeiras sob o sistema de contratos de integração vertical. Estas duas empresas coordenam o processo produtivo desde a produção de pintos de um dia até a industrialização e comercialização da carne de frango. Para a fase de engorda dos frangos, estas empresas firmam contratos com produtores avicolas, fornecendo-lhes os insumos pintos de um dia, ração e assistência técnica. Este tipo de relação contratual, será definido neste trabalho como contratos de integração vertical ou coordenação contratual.

\section{2 - O avanço da produção de frango de corte sob contrato de integração vertical}

O complexo agroindustrial avícola, dentre outras mudanças proporcionadas ao meio rural, alterou a forma de produção, integrando-a verticalmente através de contratos.

O crescimento dos métodos de produção sob a forma de contrato ganha importância na avicultura capitalista, seja nos países industrializados, seja nos denominados paises em desenvolvimento. Segundo Belato (1986), estes métodos de produção são indicadores do grau de concentração do capital no segmento agroindustrial e da vinculação da agricultura à indústria por meio da intensificação da aplicação de capital no processo direto da produção agropecuária. A subordinação direta do processo produtivo agrícola ao capital reduz, em geral, a necessidade das grandes empresas efetuarem o controle da posse da terra, reduzindo desta forma a inversão de capital.

$\mathrm{O}$ sistema integrado de produção sob contratos surgiu paralelamente à grande modernização da avicultura como processo de mudança nas estratégias organizacionais. Este sistema disseminou-se prontamente em Santa Catarina, onde não havia uma avicultura moderna em bases comerciais, como havia em São Paulo e Minas Gerais. 
Segundo Sorj et al. (1982), a avicultura industrial em Santa Catarina surgiu integrada contratualmente a partir de 1960, tomando um impulso decisivo em 1971. O autor ressalta que a razão fundamental da facilidade que as empresas integradoras tiveram para impor esta forma de relacionamento contratual foi o caráter da estrutura agrária, formada por pequenos produtores disponíveis. Em 1978, 96\% da avicultura comercial de corte no Estado estava estruturada com base nesse sistema, propiciando a Santa Catarina taxas geométricas de crescimento superiores a $50 \%$ ao ano no período 1972-1978 (Sorj et al. , 1982).

Em linhas gerais, a avicultura de granja empresarial, em todos os Estados em que ela foi introduzida na década de 1950 e especialmente de 1960, já nasceu com elevado nível tecnológico. Isto ocorreu mediante a incorporação de melhoramentos genéticos, adoção de instalações mais apropriadas e alimentação racional. Diferentemente dos Estados do Sul e até mesmo de São Paulo, que no final da década de 70 já haviam esboçado o movimento de integrar a produção das granjas aos abatedouros e fábricas de ração, a avicultura de corte no Estado de Minas Gerais desenvolveu-se no sistema de produção independente altamente pulverizada com a grande participação de pequenos produtores avicolas. Cerca de $82,83 \%$ do total de produtores avícolas do Estado de Minas Gerais em 1975, tinham uma capacidade de alojamento para menos de 10 mil aves, classificados pelos estudos técnicos como de pequeno porte, muito abaixo do minimo técnico econômico recomendável (Sorj et al., 1982).

A crise vivenciada pelo setor avicola no inicio dos anos 80 , que atingiu as empresas de incubação e grandes e médios avicultores, levantou a questão de readaptação da estrutura de produção em Minas Gerais, que poderia caminhar para as duas vertentes ao mesmo tempo, tanto o fortalecimento da verticalização como a implantação dos contratos de integração vertical, ou coordenação contratual.

$\mathrm{Na}$ verticalização, diferentes estágios produtivos do setor avícola são realizados dentro de uma só empresa, ou seja, por departamentos diferentes mas integrantes da própria empresa que é responsável pela operação administrativa de todos 
os estágios de produção. Podendo compreender a produção de matrizes, pintos de um dia, criação e abate de frangos de corte Zirlis et al. (1990).

$\mathrm{Na}$ coordenação contratual por outro lado, os diferentes estágios produtivos do setor avícola são coordenados da mesma forma que na verticalização, mas diferenciando-se pela existência de contratos firmados entre a indústria e produtores avicolas para a fase de criação dos frangos de corte. Neste tipo de relação contratual, como será analisado posteriormente, as empresas fornecem aos produtores os insumos necessários à engorda dos frangos.

Para exemplificar o caso da verticalização, Sorj et al. (1982) citam o caso da Rezende Empreendimentos Alimentícios e da Granja Igarapé Ltda., as duas maiores em Minas Gerais no final da década de 70.' Essas empresas que iniciaram como produtoras de frango de corte, evoluíram tanto, que passaram a controlar praticamente todas as fases da avicultura. Com exceção da genética, a Rezende controlava todas as fases da avicultura desde a produção de matrizes de corte até a comercialização do frango final. Com exceção das matrizes, a Igarapé era independente nas demais fases.

Existem indicações segundo Sorj et al. (1982), de que a integração vertical sob contrato possa ser uma saida estratégica para a crise de grandes empresas, devido à necessidade de descentralização da produção, à medida que a empresa atinge determinado tamanho. As dificuldades de se dispor de investimento para manter instalações necessárias à produção de frangos para abate tornam-se, cada vez maiores, devido ao grande número de aviários que é preciso construir.

Esse sistema de produção foi amplamente incentivado pela EMATER/MG como solução para os pequenos produtores. A empresa Rio Branco (Pif-Paf) segundo o mesmo autor, foi a pioneira em Minas Gerais no sistema de produção integrada, iniciada de forma experimental no final de 1980 com cerca de 80 integrados, e só em março de 1981 estava implantada em forma acabada com 180 produtores, com possibilidades de crescimento. Hoje esta empresa está trabalhando com 432 produtores integrados.

Não resta a menor dúvida que o sistema integrado de produção permitiu resolver problemas no que diz respeito à escala de produção e à qualidade do pinto de 
um dia. Segundo Lopes (1992) questões como a ração adequada, quais medicamentos utilizar, qual a técnica de manejo a adotar, entre outras, estão sendo adequadamente resolvidas pelo sistema de integração, o que certamente permite uma redução de custos.

Não se deve deixar de considerar que a integração vertical altera o local de formação de preços, reduzindo o número de pontos na cadeia de comercialização em que os mesmos são estabelecidos. A produção integrada na indústria de frango de corte podese dar em partes ou no todo da cadeia, como pode-se visualizar na Figura 1. Caso exista a contratação de produtores, ela se dá no segmento de engorda ou recria dos pintos de um dia, tendo-se desta forma a integração vertical sob contratos.

A forma como se combina a integração determina a natureza das relações que se verificam no interior da cadeia agroindustrial. Quanto maior a integração, maior a rapidez no ajuste da produção à demanda de mercado no que diz respeito à especificidade de consumo.

Por definição, nas relações de compra e venda de frango entre o produtor integrado e a empresa integradora não existe um mercado alternativo, ou seja, o produtor deverá sempre entregar o produto à empresa a que se integrou. Neste caso, os acordos mais amplamente usados no que diz respeito a preço segundo Zirlis et al . (1990), Marques (1991) e Lopes (1992) são aqueles em que a remuneração ao produtor depende acima de tudo de sua eficiência técnica, principalmente nas variáveis ganho de peso diário e conversão alimentar. De acordo com Lopes (1992), em geral, o integrado não tem a garantia do preço desejado e nenhum controle sobre a atividade; "ele apenas cumpre o que determina a supervisão". Neste sentido, pode-se considerar que os preços são estabelecidos administrativamente. 
FIGURA 1. Descrição Gráfica da Cadeia Produtiva de Frango de Corte

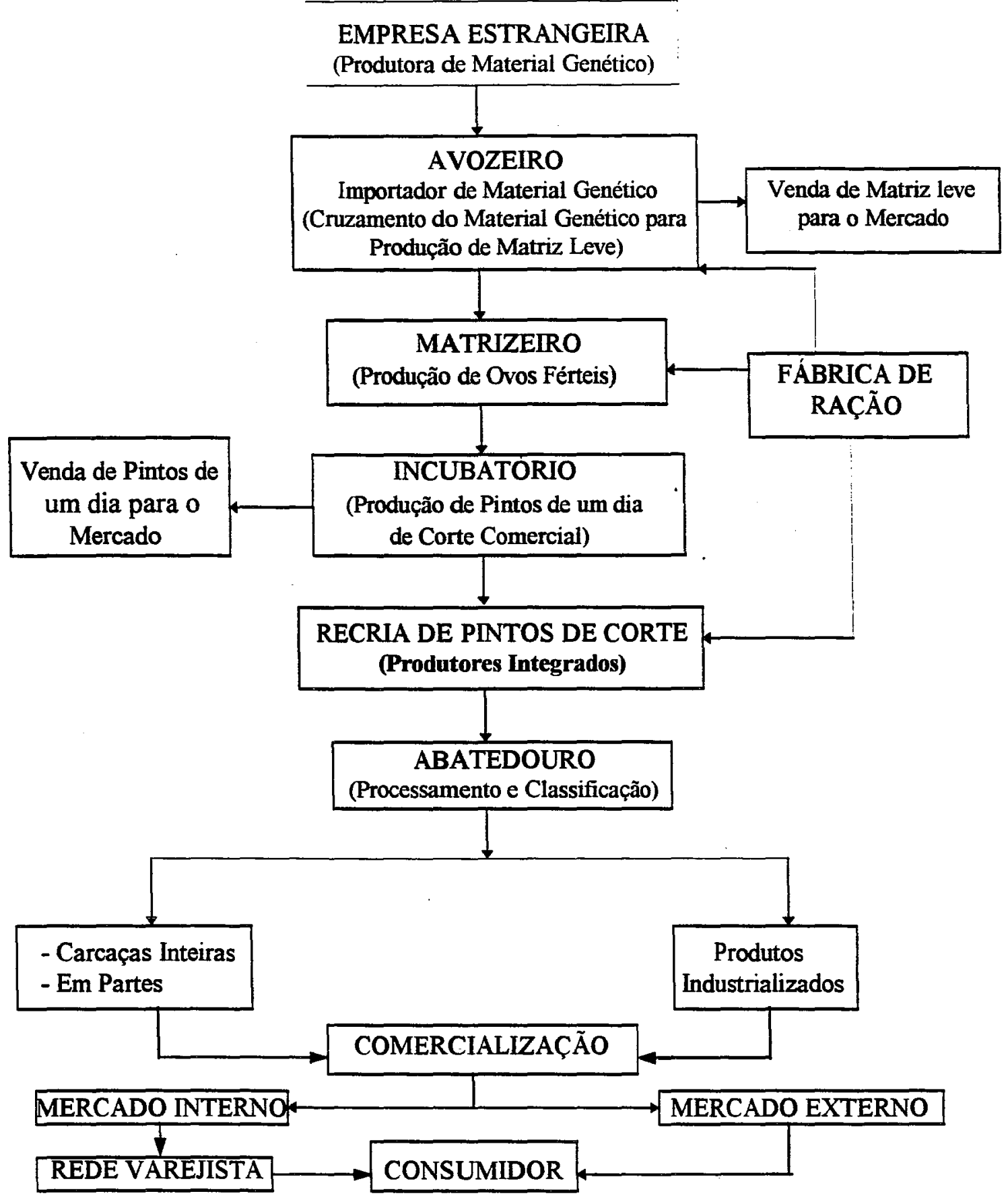

FONTE: Adaptado de Secretaria de Estado da Agricultura, Pecuária e Abastecimento/MG. Cenário Futuro para a Cadeia Produtiva de Aves e Ovos em Minas Gerais. In: Cenário Futuro do Negócio Agrícola em Minas Gerais. Belo Horizonte, 1995. v.4, p. 17 
A remuneração dos produtores neste sistema pode estar estreitamente relacionada com o poder de mercado das partes envolvidas no processo, o qual, segundo Thame \& Amaro (1982), é a capacidade de um individuo ou grupo de reforçar sua posição em relação àqueles com quem mantém negociações. A distribuição de forças entre os envolvidos condiciona o quanto caberá de remuneração a cada parte nas transą̧ões. A maneira como encontram-se organizados os produtores integrados e as empresas integradoras pode ajudar a elucidar questões pertinentes à remuneração e ao retorno obtido pelo investimento.

Alves (1988) afirma que os produtores que trabalham no sistema de coordenação, como na indústria de aves e suínos, recebem por remuneração um resíduo depois de abatidos os custos e margem de lucro estabelecida pela empresa. Segundo o autor, neste esquema o produtor perde o poder de decisão que teria caso estivesse desvinculado de uma agroindústria, embora, por outro lado, procure reduzir os riscos de mercado.

Levando-se em consideração os diversos arranjos contratuais existentes, torna-se importante comparar estas diferentes modalidades a fim de se obter informações importantes a respeito da rentabilidade do investimento feito pelo produtor, estando ele sujeito às normas técnicas e ao pacote tecnológico estabelecido pela empresa integradora. Será considerado também como fonte de incerteza o preço de mercado do frango de corte para os contratos que o utilizam nas fórmulas de remuneração.

\section{3 - Definição do problema}

No Estado de Minas Gerais, apesar da produção integrada sob contratos na avicultura ser relativamente recente, ela tem se tornado uma opção de atividade para pequenos e médios produtores, uma vez que pode ser conduzida com exigências mínimas de área e mão-de-obra, originando receita em um periodo relativamente curto, como foi analisado por Alves Filho (1994). Por outro lado, elevados índices de eficiência técnica estão direta e indiretamente relacionados com uma elevada inversão de capital fixo. Sob 
estes aspectos, os produtores investem na atividade considerando um horizonte temporal relativamente longo que envolve incerteza.

Ao analisar os contratos de integração, lo que de fato está-se tentando buscar, é uma explicação para a existência de diferentes contratos e principalmente de diferentes fórmulas de remuneração. $\dot{E}$ fato notório que neste sistema de produção o produtor integrado não se submete diretamente ao mercado, uma vez que o contrato determina a quantidade e o preço do produto. Desta forma, cumpridas as exigências feitas pelas empresas integradoras, o produtor passa a produzir para ela uma determinada quantidade e a uma forma de remuneração pré-determinada.

Neste sentido, a incerteza a que os produtores estão sujeitos vem do fato de que as empresas ao estabelecerem as fórmulas de remuneração e tabelas de coeficientes técnicos, levam em consideração um determinado pacote tecnológico, ou seja, uma determinada taxa de conversão alimentar, ou ganho de peso diário, por exemplo, podem ser previstos ou desejados. Mudanças, no entanto, podem ocorrer, ocasionando variações nestes coeficientes técnicos que $a$ priori não eram esperadas.

Estas mudanças podem se dar por um simples deslize do produtor na condução de um manejo adequado ou principalmente por fatores que escapam ao seu controle como por exemplo, qualidade do pinto de um dia, pontualidade na entrega da ração, idade de abate, entre outros.

Desta forma, torna-se crucial analisar o impacto das diferentes fórmulas de remuneração sobre a rentabilidade do investimento, sob estas condições de risco.

Alguns autores, como Zirlis et al. (1990), Guimarães (1990), Marques (1991) e Alves Filho (1994), apesar de referirem-se aos diferentes contratos de integração vertical e as correspondentes fórmulas de remuneração, deram pouca atenção ao entendimento mais aprofundado das diferenças entre as fórmulas e à razão da adoção de uma ou outra e as implicações para as partes envolvidas no processo produtivo.

Outro fator que impulsiona esta pesquisalé a carência de dados recentes quanto à estrutura do mercado de frango de corte no Estado de Minas Gerais e a representatividade do sistema de integração vertical sob contrato neste Estado. 


\section{4 -Objetivos}

A pesquisa tem como objetivo geral analisar a estrutura do mercado de frango de corte sob contrato de integração vertical, dando ênfase às diferentes fórmulas de remuneração dos produtores no Estado de Minas Gerais e o impacto dessas fórmulas na rentabilidade do investimento, sob condições de risco.

Especificamente, pretende-se:

a) Identificar a participação da produção integrada sob contratos em Minas Gerais e sua distribuição espacial;

b) Caracterizar os contratos de integração usados na produção de frango de corte em Minas Gerais;

c) Determinar a rentabilidade do investimento para o produtor, sob diferentes fórmulas de remuneração, em condições de risco;

d) Discutir as implicações práticas das diferentes fórmulas de remuneração usadas pelas integradoras no sentido de contribuir para a explicação dos preços recebidos pelos produtores. 


\section{CAPÍTULO II - REFERENCIAL TEÓRICO - METODOLÓGICO}

\section{1 - Integração vertical sob contratos}

Quando se observa qualquer mercado, percebe-se que a produção de um determinado bem envolve diferentes estágios de produção. Marques (1991) define estágios de produção como as diferentes fases do processo de produção, desde o produtor até o consumidor, em que há troca de propriedade do produto sem que o bem seja consumido, ou seja, sem que ele desapareça proporcionando satisfação.

Estes diferentes estágios podem ocorrer dentro de uma firma ou entre firmas. Como definido por Barros (1987), firma é qualquer organização econômica que tem por finalidade a produção de bens ou serviços econômicos. A coordenação destes diferentes estágios pode, segundo o autor, se dar interna ou externamente. A coordenação interna ocorre quando os diferentes estágios são controlados por uma firma; a coordenação externa se dá quando os estágios situam-se em diferentes firmas e coordenam-se através do funcionamento do sistema de preços.

O termo integração será utilizado aqui para descrever o aspecto organizacional da produção de frango de corte, no sentido de especificar a forma como os diferentes estágios estão coordenados.

O processo de integração pode ser horizontal e vertical. A integração é denominada horizontal quando ocorre a combinação de dois ou mais estágios laterais de produção e/ou distribuição sob a propriedade e/ou controle de uma firma. Ou seja, dois ou mais segmentos são unidos no mesmo estágio de operação.

De acordo com Roy (1972), a integração vertical refere-se à combinação de dois ou mais estágios sucessivos de produção e/ou distribuição sob a propriedade ou 
controle de uma firma. Neste caso, a integração pode ser "para frente", quando uma firma move-se para o estágio de produção subsequente; e a integração será "para trás", quando uma firma localizada em um estágio de produção passa a produzir também matéria-prima ou outros insumos.

A maneira como a integração vertical foi definida assemelha-se à definição de coordenação vertical formulada por King (1992). Segundo ele a coordenação vertical é o alinhamento da direção e controle através de segmentos de um sistema de produção e/ou comercialização. Estes conceitos podem ser também considerados como verticalização.

Sandroni (1985) define a verticalização como a atuação de uma empresa em mais de um estágio do processo produtivo, o que segundo ele, freqüentemente ocorre por meio da fusão de várias empresas que atuam em estágios diferentes. $O$ mais abrangente tipo de verticalização ou integração vertical é o da empresa que faz desde o processamento da matéria-prima até o acabamento final e distribuição do produto.

A coordenação contratual na agricultura, por outro lado, baseia-se segundo Lopes (1992), em transações firmadas entre produtores agrícolas e empresas agroindustriais, em que são especificadas uma ou mais condições de produção e/ou comercialização.

Schrarer ${ }^{1}$ (1986), citado por Lopes (1992), acredita que as razões para uma empresa mudar do mercado aberto para a coordenação contratual são basicamente as mesmas que a levam a mudar para a integração vertical ou horizontal.

Vários incentivos poderiam ser listados para a integração vertical. Barros (1987) cita os seguintes: redução de riscos, melhoria na administração, conquista de maior poder de barganha e obtenção de insumos adequados. Williamson (1989), por outro lado, coloca a especificidade dos ativos como um dos principais incentivos à integração, ou seja, quanto mais específico for um ativo, maiores serão os custos de

\footnotetext{
${ }^{1}$ SCHRADER. L.F. Responses to forces shaping agricultural marketing: contracting. American Journal of Agricultural Economics, v. 68, n. 5, p. 1161 - 1166. Dec. 1986.
} 
transações do mercado, e se nas transações existir um alto grau de incerteza, tem-se um ambiente favorável ao surgimento da integração.

Kohols \& Wiley ${ }^{2}$ (1955); Seaver ${ }^{3}$ (1957) e Scherer $^{4}$ (1970) citados por Marques (1991), afirmam que as empresas integram-se para aumentar sua eficiência econômica, que ocorre em função de:

- redução nos custos provenientes de ganho de escala;

- evitar custos associados com o mecanismo de preço de mercado;

- permitir à própria empresa apropriar-se de ganhos que de outra forma seriam auferidos por outros intermediários.

Do lado dos produtores, os mesmos autores argumentam que eles integram-se pelas seguintes razões:

- neste sistema reduz-se a incerteza quanto ao preço que o produtor receberá pela sua produção;

- a empresa integradora, por ter interesse na qualidade e homogeneidade da produção, fornece assistência técnica de qualidade mais alta que a tradicionalmente oferecida pelos órgãos públicos, elevando-se os índices de produtividade técnica dos produtores.

O contrato de produção tem-se apresentado como componente básico do processo de integração vertical e é definido como:

"o relacionamento e dependência direta entre produção agropecuária e empresa integradora, que pode ser formulado explicitamente através de contratos escritos ou oralmente. $O$ conteúdo desses contratos ou pactos, formulados juridicamente ou não, diz respeito substancialmente à exclusividade na aquisição dos insumos por parte do produtor rural, ao padrão tecnológico e manejo a ser posto em prática

${ }^{2}$ KOHLS, R.L. \& J.W. WILEY. Aspects of multiple-owner integration in the broiler industry. Journal of Farm Economics, v. 37, n. 1, p. 81 - 89, 1955.

${ }^{3}$ SEAVER.K.S. Anappraisal of vertical integration in the broilet industry. Journal of farm Economics, Cambridge, v. 39, n. 5. p. 1487 - 1499, 1957.

${ }^{4}$ SCHERER, F.M. Industrial market structure and economic performance. Chicago, Rand McNally College Publishing, Co., 1970. 
sob orientação e assistência técnica da empresa e, fundamentalmente, à exclusividade e garantia da produção agropecuária por parte da empresa integradora" (Sorj et al., 1982, p. 42).

A coordenação contratual assume diversas formas e variações. Conforme identificado por Roy (1972) pode ser subdivididos em dois sub-tipos: um com cláusulas de controle limitado e o outro com cláusulas de completo controle sobre o processo de produção e comercialização.

No caso dos contratos com cláusulas de controle limitado, segundo Belato (1986a), a empresa fornece ao produtor um certo conjunto de insumos, podendo ou não comprar a produção, condicionada à qualidade do produto. Neste caso não há garantia de preço. $\mathrm{O}$ produtor torna-se atado à empresa em alguns pontos estratégicos mas, em geral, a firma não necessita tomar as decisões em substituição ao produtor. Este tipo de contrato segundo o autor, apresenta uma forte participação na produção de frutas e verduras, e é denominado contrato de "especificação de compra e venda" e "controle de qualidade".

No segundo tipo encontram-se os contratos de integração em que as cláusulas contratuais estabelecem um total controle da produção. Nestas condições o produtor deve seguir rigidamente as normas expressas no contrato e permitir uma rigorosa supervisão de suas atividades. A empresa contratante mantém a propriedade dos insumos $\mathrm{e}$ do produto final $\mathrm{e}$ também assume a responsabilidade pela sua comercialização. Neste caso, encaixam-se bem a produção de aves e de suínos. Os contratos firmados sob este tipo de relação sempre especificam as condições de preço e formas de pagamento, em que a empresa controla os custos e os preços da produção a partir de seus próprios custos e não a partir dos custos dos produtores.

A produção por meio de contratos é muito difundida e a despeito da dificuldade em classificá-los dada a multiplicidade de aspectos envolvidos, o BADESP (1978) distinguia basicamente dois tipos: contrato limitado e contrato integral. A principal característica do contrato limitado é a garantia de mercado para o contratado 
junto ao contratante, desde que o produto obedeça a determinadas especificações. Este tipo de contrato assemelha-se aos contratos de especificação de compra e venda e controle de qualidade definidos por Belato (1986a).

No contrato integral são fixados preços por unidade de produção, bem como estipulados prazos para a entrega da produção e supervisão da atividade pelo contratante. Neste caso, o produtor livra-se de certos riscos, principalmente a aquisição dos insumos e comercialização do produto. No entanto, estes são mais rigorosos e específicos que os contratos limitados, havendo situações em que os produtores recebem todos os insumos, ou grande parte deles, como é o caso dos produtores de frango de corte que recebem do contratante os pintos de um dia, a ração e os medicamentos. Como o contratante assume o risco adicional de perder os insumos investidos, tem interesse em controlar praticamente todos os pormenores da produção, além de reivindicar maior parcela dos lucros obtidos.

Dornbusch e Boehlje ${ }^{5}$ (1988) citados por Lopes (1992), identificaram seis diferentes formas de produção de perus nos Estados Unidos:

1. Integração Vertical - o produtor processador possui toda a produção, instalações e contrata mão-de-obra para manejar as aves, assumindo todo risco na interface produtorprocessador. A determinação do preço pode ser baseada no custo de aves adultas ou na cotação de mercado;

2. Cooperativas - é bastante parecido com a forma de produção acima, no qual um grupo de produtores assume os riscos da atividade;

3. Contratos com fornecimento de recursos - neste tipo de contrato, o processador fornece as aves novas, ração, supervisão técnica e outros fatores, ficando a cargo do produtor o investimento em instalações e equipamentos, bem como a mão-de-obra para o manejo das aves. A remuneração ao criador é por ave adulta entregue para o abate, que inclui incentivos para o desempenho na conversão alimentar e mortalidade;

\footnotetext{
${ }^{5}$ DORNBUSCH. C.W. \& BOEHLJE, M. An economic analysis of contracting arrangements used by the Minnesota turkey industry. St. Paul, University of Minnesota, p. 37, 1988. (Staff Papers Series: Staff Paper, 88-17).
} 
4. Contratos "Cost-Plus"- nos arranjos desta natureza, a remuneração ao produtor é baseada nos custos dos fatores estimados em um patamar de desempenho-padrão, mais uma margem de lucro. Este tipo de contrato difere do anterior à medida que coloca certos riscos de produção a cargo do criador,

5. Criadores Independentes - os criadores fazem um contrato especificando um número de aves, cujo preço vai ser dado, utilizando-se uma cotação de mercado na data do abate ou na cotação média da semana; $e$,

6. Riscos Partilhados - os criadores independentes e os processadores estimam os custos de criação relativos à produção, e o valor de mercado é usado na transação. Se o valor de mercado desvia-se do custo de produção, as diferenças são partilhadas pelos produtores e processadores.

A produção avicola brasileira hoje está fortemente assentada no sistema de contratos de integração vertical e mesmo acreditando que eles possam variar de empresa para empresa, bem como de região para região, provavelmente guardam entre si as características explícitas no terceiro tipo de contrato, que não difere substancialmente do contrato integral definido conceitualmente pelo BADESP (1978).

\subsection{1 - Sistemas de remuneração e suas implicações na rentabilidade do investimento}

Os contratos de integração geralmente estabelecem direitos e deveres da empresa contratante e do produtor contratado (ver diferentes contratos no Apêndice 1). De um modo geral, o resultado final de um lote de frango produzido pelos produtores integrados pode ser influenciado por vários fatores, quais sejam:

$\Rightarrow$ qualidade dos pintos de um dia, ração e assistência técnica fornecidos pelas empresas integradoras; $\mathrm{e}$

$\Rightarrow$ capacidade individual de cada produtor absorver as instruções dadas pelos técnicos, resultando com isto, na aplicação de um determinado manejo. Ressalte-se, no entanto, que um bom produtor tende a melhorar o seu desempenho, enquanto um produtor considerado de baixa produtividade tende a ser excluído deste sistema de produção. 
Pressupondo, que não existam diferenças significativas na qualidade dos insumos e assistência técnica entre as empresas integradoras e, respeitadas as características intrínsecas de cada produtor, a distinção fundamental entre os produtores das diferentes empresas, é a rentabilidade que cada um deles obtém do investimento realizado, diferenciação esta, considerada aqui como resultado da aplicação de diferentes fórmulas de remuneração.

Como foi visto anteriormente (item 1.2), as empresas contratantes utilizam variáveis técnicas para avaliar o desempenho do produtor e consequentemente estabelecer o quanto ele receberá pelo lote de frango entregue. Alguns contratos (contratos A e B, Apêndice 1), utilizam também como variável na determinação da remuneração o preço do quilo de frango vivo, cotado pela Associação Paulista de Avicultura (APA). De maneira geral, o preço utilizado é o cotado na data de saída dos frangos da granja.

As variáveis técnicas utilizadas para a avaliação do desempenho são: taxa de mortalidade (M), ganho de peso diário (GPD), conversão alimentar (CA), peso médio (PM) e idade, que podem ser relacionadas da seguinte forma:

$$
\mathrm{M}=\left(\frac{\mathrm{QPA}-\mathrm{NFE}}{\mathrm{QPA}}\right) \times 100
$$

em que:

$M=$ Taxa de Mortalidade;

QPA = Quantidade de Pintos Alojados;

$\mathrm{NFE}=$ Números de Frangos Entregues

$$
\mathrm{PM}=\frac{\mathrm{PTE}}{\mathrm{NFE}}
$$

em que:

$\mathrm{PM}=$ Peso Médio 
PTE $=$ Peso Total Entregue;

NFE = Números de Frangos Entregues;

$$
\text { GPD }=\frac{\text { GPTE }}{\text { NFE }} \times \frac{1}{\text { Idade }}
$$

em que:

GPD = Ganho de Peso Diário;

GPTE $=$ Ganho de Peso Total Entregue, que é o peso final menos peso inicial;

$\mathrm{NFE}=$ Números de Frangos Entregues;

Idade $=$ Tempo de Alojamento (em dias)

$$
\mathrm{CA}=\frac{\mathrm{CTR}}{\mathrm{GPTE}}
$$

em que:

$\mathrm{CA}=$ Conversão Alimentar;

CTR = Consumo Total de Ração;

GPTE $=$ Ganho de Peso Total Entregue

Estas variáveis são combinadas de diferentes maneiras, originando diferentes formas de remuneração. Para o Estado de Minas Gerais, foram verificadas as seguintes:

\section{Contrato A:}

Os resultados de peso médio e conversão alimentar são combinados em uma tabela (ver tabela, contrato $\mathrm{A}$, Apêndice 1), que fornecerá o percentual a que terá direito $\mathrm{o}$ produtor em quilos de aves vivas. A fórmula de remuneração em valor monetário por lote produzido é então a que se segue: 
Rem. $\mathrm{em} \mathrm{R}$ /Lote $=($ PTE $\times$ Percentual $) \times$ Preço APA

em que:

$\mathrm{PTE}=$ Peso Total Entregue em Kg;

Percentual $=$ Percentual alcançado dado a combinação de peso médio e conversão alimentar;

Preço APA = Preço do quilo de frango vivo cotado pela Associação Paulista de Avicultura, vigente na semana do abate.

\section{Contrato B:}

Rem. em R\$/Lote $=($ PTE $\times$ Percentual $) \times$ Preço APA

Neste caso, o percentual alcançado é definido inicialmente pelo Índice de Eficiência e Produtividade (IEP), que é dado pela seguinte expressão:

$$
\mathrm{IEP}=\frac{\mathrm{PM} \times \text { Viabilidade }}{\mathrm{CA} \times 1 \text { Idade }} \times 100
$$

em que:

PM = Peso Médio;

Viabilidade $=$ Inverso da Mortalidade;

$\mathrm{CA}=$ Conversão Alimentar;

Idade $=$ Tempo de Alojamento (em dias)

De acordo com o IEP obtido, procura-se na tabela (contrato B, Apêndice 1) o percentual correspondente.

\section{Contrato C:}

$$
\text { Rem. } \mathrm{em} \text { R } / \text { Lote }=\text { Alíquota } \times \text { Peso Total Entregue } \times 0,7
$$

em que:

Alíquota $=9 \%+($ FP - FP médio $) \times 0,2$ 
O Fator de Produtividade (FP) é dado pela seguinte expressão:

$$
\text { Fator de Produtividade }=\frac{\text { GPD } \times \text { Viabilidade }}{\text { CA }} \times 10
$$

em que:

GPD = Ganho de Peso Diário;

Viabilidade $=$ Inverso da Mortalidade;

CA = Conversão Alimentar.

O FP médio, é o fator de produtividade médio de todos os produtores integrados, calculado com base nos últimos dez lotes produzidos.

\section{Contrato D:}

No contrato $D$, inicialmente é definida a pontuação que é função da taxa de mortalidade, conversão alimentar, ganho de peso diário, taxa de contusão ${ }^{6}$, tempo gasto com o carregamento dos frangos e manejo. Para as seis (6) primeiras variáveis, existe uma tabela com os índices e números de pontos correspondentes. A variável manejo é a nota dada pelo técnico, convertida em pontos, que varia de ótimo a ruim (ver tabelas, contrato $\mathrm{D}$, Apêndice 1)

Calculada a pontuação, determina-se a remuneração pelo lote produzido, que é dada pela seguinte expressão:

Rem. em R\$/Lote $=($ Pontuação $\times$ Valor do Ponto $) \times$ Número de Frangos Entregue $(10)$

$$
\text { Valor do Ponto }=\left(\frac{\text { Planilha de Custo }}{\text { CAMOT }}\right) / \text { PM }
$$

em que:

\footnotetext{
${ }^{6}$ Taxa de contusão é o percentual de carcaça rcjcitada pclo Scrviço de Inspcção Fcderal - SIF, durante o abate.
} 
Planilha de Custo $=$ Custo de produção calculado para um galpão padrão com $1200 \mathrm{~m}^{2}$. O custo de produção inclui gastos com mão-de-obra para manejo, limpeza e apanha dos frangos, gasto com material para a cama, energia elétrica e material para desinfeção.

CAMOT = Capacidade de Alojamento Média Ocupada no Trimestre;

$\mathbf{P M}=$ Pontuação Média alcançada pelos produtores no trimestre.

Alguns fatores importantes alteram os resultados dos coeficientes utilizados nas fórmulas. Se o pinto de um dia é de boa qualidade, a mortalidade na primeira semana será relativamente baixa; o mesmo terá um bom ganho de peso diário e isto, automaticamente, refletirá em maior peso de ave viva por quilo de ração consumida, ou seja, boa conversão alimentar e naturalmente maior peso médio. A idade de alojamento influencia diretamente o ganho de peso diário. Aves mais pesadas têm conversão alimentar mais alta e geralmente maior taxa de mortalidade devido ao "stress". Uma das empresas pesquisadas, procura no contrato, fornecer ao produtor algum tipo de abono, para que ele não seja penalizado. Isto ocorre porque às vezes a empresa tem preferência por aves mais pesadas.

A determinação da relação entre as variáveis torna-se importante, não só para mostrar a interdependência entre elas, mas também para salientar que o resultado financeiro alcançado pelo produtor está associado a algumas variáveis, que neste sistema de produção, escapam totalmente ao seu controle.

Feitas estas considerações, pode-se concluir que, além da qualidade do manejo, que expressa o cuidado do produtor com o plantel, fator básico para distinguir um produtor do outro, o que fundamentalmente determina a rentabilidade do investimento para o produtor é a ponderação que as variáveis estabelecidas recebem em cada fórmula de remuneração.

\section{2 - Avaliação econômica de projetos}

Tendo em vista que o objetivo central da dissertação é a análise do impacto das diferentes fórmulas de remuneração na rentabilidade do investimento para o 
produtor integrado, sob condições de risco, faz-se necessária uma descrição do procedimento de avaliação econômica de projetos.

A análise econômica de projetos constitui-se em um importante instrumento para a tomada de decisão sobre o investimento. No caso dos produtores integrados, o projeto está associado à construção do galpão e a compra de equipamentos necessários à engorda das aves.

Segundo Noronha (1987), ao se decidir por um projeto de investimento, deve-se considerar as consequiências futuras das decisões tomadas no presente. Qualquer investimento de capital implica certo dispêndio de dinheiro em bens duráveis (bens de capital) destinados a produzir outros bens durante certo período definido de tempo no futuro.

Existem vários métodos para avaliar a viabilidade de um projeto de investimento. Problemas relacionados com a conceituação, bem como vantagens e desvantagens dos diversos critérios são discutidos por Contador (1981), Noronha (1987), e Woiler (1987).

No presente trabalho será utilizada a Taxa Interna de Retorno (TIR) como método de avaliação econômica do investimento.

Este método, segundo Noronha (1987), consiste na determinação do valor da taxa de desconto que torna o valor presente do fluxo líquido igual a zero. Em outras palavras, é a taxa que equaliza o valor presente de um ou mais pagamentos (saídas de caixa) com o valor presente de um ou mais recebimentos (entradas de caixa). A equação que fornece a taxa interna de retorno (TIR) pode ser escrita como segue:

$$
\sum_{i=1}^{n} \frac{\left(B_{i}-C_{i}\right)}{(1+j)^{n}}=0
$$

em que $\mathrm{j}$ é a TIR; $\mathrm{B}_{\mathrm{i}}$ é o beneficio do projeto em unidades monetárias no ano $\mathrm{i} ; \mathrm{C}_{\mathrm{i}}$ é o custo do projeto em unidades monetárias no ano i e n é a vida útil do projeto.

A escolha deste método justifica-se pelas vantagens a ele associadas, que de acordo com Noronha (1987) são: 
a) representa uma taxa de juros sobre o investimento, portanto, pode ser comparada diretamente com o custo do capital;

b) é calculada internamente a partir do fluxo de caixa do projeto, logo não se precisa conhecer o fator de desconto.

Segundo o autor, para que a taxa interna de retorno seja um ferramental adequado, é necessário conhecer inicialmente o custo do capital, para que comparando-o com a TIR, tome-se uma decisão adequada da aceitação do projeto. Esta mesma argumentação foi feita também por Contador (1981).

Noronha (1987) sugere que se compare a taxa interna de retorno com o custo médio ponderado do capital (CMPC), que representa o retorno mínimo para compensar a inversão de capital no projeto. Para o cálculo do custo médio ponderado do capital é necessário identificar as proporções de recursos próprios e de terceiros necessárias à implantação do projeto, bem como seus respectivos custos. De acordo com este autor, o custo médio ponderado do capital é dado por:

$$
\mathrm{K}=\mathrm{K}_{\mathrm{p}} * \alpha+\mathrm{K}_{\mathbf{e}} *(1-\alpha)
$$

em que:

$\mathrm{K}_{\mathrm{p}}=$ custo do capital próprio;

$\mathrm{K}_{\mathrm{e}}=$ custo do capital de terceiros; $\mathrm{e}$

$\alpha=$ proporção do capital próprio no projeto.

Como visto anteriormente, para que se possa calcular a taxa interna de retorno é necessária a elaboração do fluxo de caixa do projeto em questão. Os fluxos de caixa são definidos como os valores monetários que refletem as entradas e saídas dos recursos e produtos por unidade de tempo que formam uma proposta de investimento.

Para o caso da produção de frango de corte sob contratos de integração vertical, fazem parte dos fluxos de entrada os valores monetários obtidos das seguintes fontes:

a) valor recebido pelo lote de frango entregue à empresa integradora;

b) venda da "cama" ou esterco do frango; $e$ 
c) valor residual de todos os bens de capital que ultrapassem o horizonte do projeto.

Fazem parte dos fluxos de saída:

a) despesas de investimento - são todos os gastos com bens de capital, inclusive despesas que se incorporam aos dos bens de capital na fase de construção do galpão para a engorda das aves;

b) despesas operacionais - passada a fase de implantação do projeto, despesas operacionais são aquelas necessárias para o funcionamento do processo produtivo.

O galpão e equipamentos têm respectivamente vida útil estimada de 25 e 15 anos. Tendo em vista a duração dos equipamentos, será considerado para efeito de análise do investimento, o tempo de utilização de 15 anos, de acordo com Lopes (1992). Uma descrição mais detalhada do fluxo de caixa será feita no item 2.3.2.

\subsection{1 - Método de simulação para análise de incerteza na avaliação econômica de projeto}

De maneira geral, a análise econômica é um processo anterior à implementação e efetivação dos projetos. Desta forma, independente do indicador escolhido (Taxa Interna de Retorno ou Valor Presente), na análise em condições deterministicas, as informações sobre as variáveis (preço e produtividade, por exemplo) utilizadas para elaboração do fluxo de caixa, são estimativas dos valores que efetivamente ocorrerão ao longo do horizonte do projeto.

Como não existe nenhum método que possibilite conhecer "ex ante" os valores exatos de todas as variáveis para a geração do fluxo de caixa do projeto, será utilizada a técnica de simulação com o objetivo de se incorporar incerteza no processo de avaliação do projeto.

Mesmo tendo conhecimento de que o grau de incerteza dos coeficientes técnicos (conversão alimentar e ganho de peso diário, por exemplo), é menor do que em relação às variáveis econômicas (preço do frango, preço da mão-de-obra, por exemplo), no presente trabalho, a técnica de simulação será utilizada para fazer variar os 
coeficientes técnicos alcançados pelos produtores em cada lote de frango produzido, visando determinar o impacto das diferentes fórmulas de remuneração na rentabilidade do investimento.

Isto será feito, porque como foi visto anteriormente, neste sistema de produção, o produtor não se submete diretamente ao mercado para determinação do preço do frango. Especificamente para os contratos a serem analisados neste trabalho, este preço é determinado pelas fórmulas de remuneração anteriormente definidas no item 2.1.1.

De acordo com Azevedo Filho (1988), para a análise econômica de projetos em que se considera a incerteza, é aconselhável a utilização de técnicas associadas à simulação de Monte Carlo. Este método foi utilizado em vários trabalhos para análise de projetos agropecuários, podendo-se citar Noronha (1982), Sá (1985), Shirota \& Silva (1985), Latápia (1988), Lopes (1992), entre outros.

Segundo Noronha (1987), deve-se seguir quatro etapas na seqüência dos cálculos no método de simulação de Monte Carlo:

1) identificar a distribuição de probabilidade de cada uma das variáveis relevantes do fluxo de caixa do projeto. As demais variáveis serão consideradas como determinísticas (valor constante);

2) sortear ou selecionar ao acaso um valor de cada variável, a partir de sua distribuição de probabilidade e combinar este valor com as variáveis deterministicas;

3) calcular o indicador de escolha (no presente trabalho será a TIR) cada vez que for feito o sorteio indicado no item 2 ;

4) repetir o processo até que se tenha uma confirmação adequada da distribuição de freqüência do indicador de escolha. Esta distribuição servirá de base para a tomada de decisão.

Este método pressupõe que as variáveis a serem simuladas sejam aleatórias, isto é, que cada valor da referida variável esteja associado a uma probabilidade. 


\subsection{2 - Identificação da distribuição de probabilidade}

De acordo com Noronha (1987), o mais comum na prática, é não se conhecer a forma da distribuição de probabilidade de cada uma das variáveis, embora sejam conhecidas, em teoria estatística várias distribuições.

A definição das distribuições de probabilidade associadas às variáveis que definem o fluxo de caixa do projeto é, em muitos casos, um processo subjetivo, que é influenciado pelo nivel de informação disponivel, Azevedo Filho (1988). Por outro lado, se for possível obter séries de observações de dados passados das variáveis que se deseja simular, pode-se através de análises estatísticas, inferir o formato da distribuição de ocorrência destes dados.

Segundo DeGroot (1986), em processos que envolvem variáveis aleatórias contínuas ou discretas, o valor da função de distribuição $F_{X}$ é a probabilidade que a variável $(\mathrm{X})$ possa assumir um valor $\mathrm{X}$ ou menor.

Se a variável aleatória $(X)$ for contínua, $F_{X}(x)$ denota sua função de distribuição e $f_{X}(x)$ sua função de densidade de probabilidade. Nesse caso, a probabilidade de $(x)$ em qualquer ponto é zero e $F_{X}(x)$ será definida em todo o intervalo $[0,1]$ tal que:

$$
F_{X}(x)=P(X \leq x)=\int_{-\infty}^{x} f(Z) d Z
$$

em que $f(Z)$ representa o valor da função densidade de probabilidade da variável aleatória quando $X=Z$.

De acordo com Sá (1985), o valor simulado da variável aleatória é obtido pelo método da transformação inversa. Se por exemplo, a variável aleatória $(X)$ a ser simulada apresenta distribuição normal, a sua função densidade de probabilidade é dada pela seguinte expressão:

$$
f_{X}(x)=\frac{1}{\sqrt{2 \pi \sigma^{2}}} \exp \left\{\frac{-(x-\mu)^{2}}{2 \sigma^{2}}\right\}
$$


em que:

$\mu$ é a média e $\sigma^{2}$ é a variância da variável aleatória $X$. Neste caso, conhecidos estes dois valores é possível prosseguir no método de simulação de Monte Carlo.

A figura 2 é a representação gráfica da função de densidade de probabilidade de uma variável aleatória $(\mathrm{X})$ com distribuição normal.

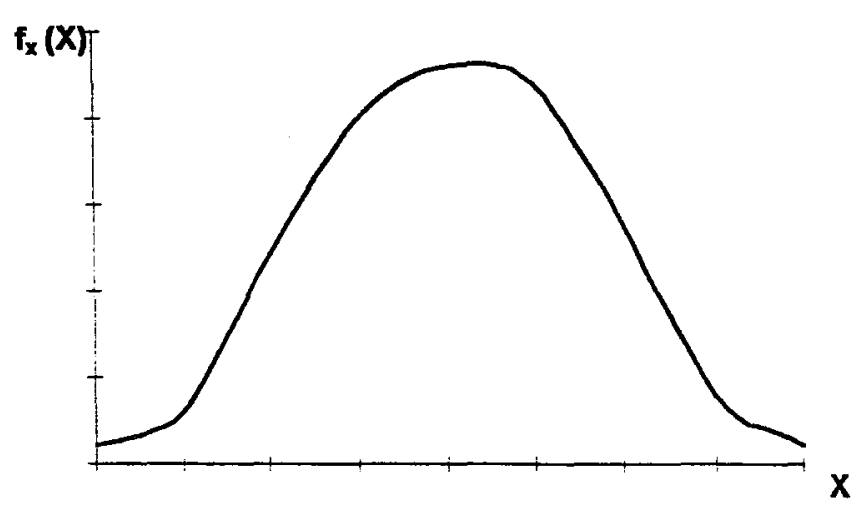

Figura 2- Função Densidade de Probabilidade de uma Variável Aleatória $(\mathrm{X})$ com Distribuição Normal

A partir da função de densidade de probabilidade (expressão15), pode-se obter a função de distribuição que é dada pela expressão:

$$
F_{X}(x)=\frac{1}{\sigma \sqrt{2 \pi}} \int_{-\infty}^{x} \exp \left\{\frac{-(x-\mu)^{2}}{2 \sigma^{2}}\right\} d x
$$

A curva mostrada na figura 3 é a função de distribuição $F_{X}(x)$. Uma vez que esta função é definida em todo o intervalo $[-\infty,+\infty]$, pode-se gerar números aleatórios $\left(Z_{0}\right)$, uniformemente distribuidos e fazer $F_{X}(x)=Z_{0}$ 


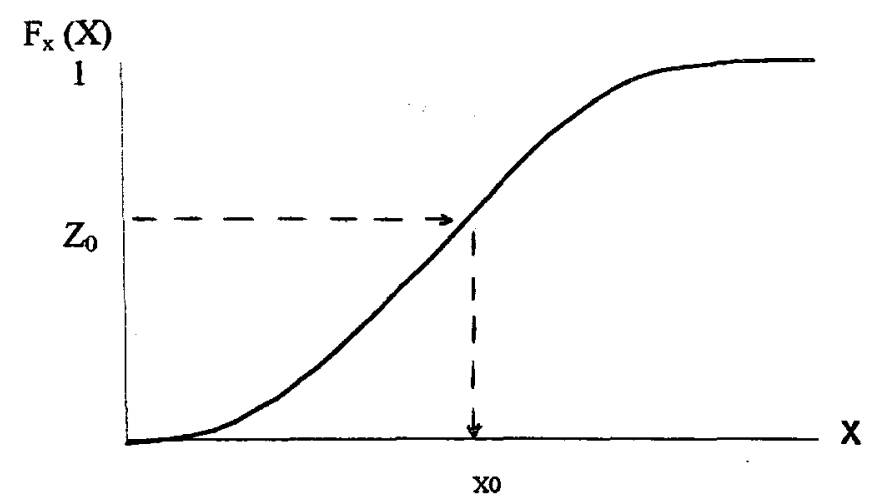

Figura 3 - Função de Distribuição e a Determinação do Valor Simulado de uma Variável Aleatória $(\mathrm{X})$, com Distribuição Normal

A partir dos números gerados ${ }^{\top}\left(Z_{0}\right)$, que representam as probabilidades daqueles valores ocorrerem, determinam-se os valores simulados $\left(\mathrm{x}_{0}\right)$, a partir da função de distribuição, dada pela expressão (16). Neste caso, os valores da média $(\mu)$ e da variância $\left(\sigma^{2}\right)$ devem ser previamente conhecidos.

Graficamente tem-se que, cada número aleatório $\left(Z_{0}\right)$ na figura 3, determina univocamente um valor de $(x)$. Este valor de $(x)$ será um novo valor do coeficiente técnico, que será utilizado para calcular a remuneração do produtor e, posteriormente o fluxo de caixa, para então determinar a taxa interna de retorno.

\section{3 - Procedimento metodológico e fonte de dados}

\subsection{1- Identificação dos contratos}

Em visita a sete empresas integradoras do Estado de Minas Gerais, buscou-se informações de como as mesmas conduziam a produção de frango de corte sob contrato. Foram obtidos diferentes contratos e mesmo para as empresas que não os forneceram, foi possivel, através do questionário aplicado a cada uma delas, detectar

\footnotetext{
${ }^{7}$ O processo de simulação foi realizado em computador com um programa específico para cada contrato, desenvolvido pelo analista de sistema José Celso $\mathrm{C}$. de Abreu, funcionário do Centro de Informática na Agricultura (CIAGRI), da Universidade de São Paulo - USP, utilizando-se o Microsoft Excel 5.0.
} 
pontos em comum, como também as diferenças na condução do sistema de produção. Cabe, no entanto, salientar que foi possível tomar conhecimento das fórmulas de remuneração dos sete contratos.

Para efeito de análise, do total de sete(7) empresas visitadas, o trabalho será conduzido para quatro contratos. Isto será feito porque detectou-se que um grupo de três empresas apresentava contrato e fórmula de remuneração idênticos. $\mathrm{E}$ em outro grupo de duas empresas isto também foi verificado.

Os contratos foram identificados como A, B, C e D e encontram-se no Apêndice 1, com as referidas fórmulas e tabelas de remuneração. Para o contrato identificado por $\mathrm{C}$, do qual não foi possível obter uma cópia, serão apresentados apenas a fórmula de remuneração e algumas informações obtidas através do questionário.

Por apresentarem as mesmas características, todos os contratos foram enquadrados nas definições de contratos com fornecimento de recursos ou contrato integral. A partir destes contratos elaborou-se modelos financeiros para avaliação econômica dos mesmos e posterior comparação dos resultados.

\subsection{2- Elaboração do fluxo de caixa}

Basicamente a estrutura do fluxo de caixa utilizada neste trabalho é a apresentada no Quadro 3.

Em geral, os produtores integrados têm três fontes de receitas na produção de frango de corte. A entrega do frango (EF) é o valor monetário que ele receberá pela engorda dos mesmos, de acordo com o resultado alcançado no que diz respeito às variáveis técnicas e fórmula de remuneração preestabelecida nos diferentes contratos. 
QUADRO 3 - Modelo Esquemático do Fluxo de Caixa

\begin{tabular}{|lcccccc|}
\hline \multicolumn{1}{|c}{ DISCRIMINAÇÃO } & \multicolumn{5}{c|}{ ANO } \\
\hline A - Receita & 1 & 2 & $\ldots$ & 14 & 15 \\
\cline { 2 - 7 } 1- Entrega do Frango (EF) & EF1 & EF2 & $\ldots$ & EF14 & EF15 \\
2- Venda da Cama de Frango & (VCF) & VCF1 & VCF2 & $\ldots$ & VCF14 & VCF15 \\
3- Fundo de Galpão (FG) & FG1 & FG2 & $\ldots$ & FG14 & FG15 \\
4- Valor Residual (VR) & - & - & - & - & VR15 \\
B - Despesas & & & & & \\
1- Investimento (I) & I1 & & & & \\
2- Despesas Operacionais (DO) & DO1 & DO2 & $\ldots$ & DO14 & D015 \\
\hline Fluxo Líquido (A - B) & FL1 & FL2 & $\ldots$ & FL14 & FL15 \\
\hline
\end{tabular}

Os valores originais encontram-se no Apêndice 2

Considera-se que o produtor produz seis lotes de frango em 12 meses, isto porque o ciclo médio de produção de frango de corte gira em torno de 45 dias para a engorda e 15 dias de vazio sanitário $^{8}$. Cabe ressaltar, no entanto, que este valor pode ser alterado em função do mercado consumidor. Caso sejam necessários frangos mais pesados, maior número de dias de alojamento serão necessários, diminuindo o número de lotes no ano, podendo o contrário também ocorrer.

De acordo com Lopes (1992) e Alves Filho (1994), um grande incentivo para a entrada e permanência dos produtores neste sistema de produção é exatamente o valor da cama de frango, resultante não apenas da sua comercialização, mas fundamentalmente da sua utilização na propriedade como fonte de adubo orgânico ou ração animal.

Com o propósito de analisar esta hipótese, o valor da cama de frango utilizado no fluxo de caixa não será fixo. Para medir a sensibilidade da taxa interna de

\footnotetext{
${ }^{8}$ Vazio sanitário ć o tcmpo nccessário para a retirada do cstcrco de frango, limpcza do galpão, desinfeç̧ão e colocação da nova cama de frango para recebimento do novo lote.
} 
retorno em relação a esta variável, será utilizado inicialmente o valor médio da tonelada, observado no periodo em análise (fevereiro de 1995 a fevereiro de 1996). Este valor foi de $\mathrm{R} \$ 56,60$ a tonelada, a preço de fevereiro de 1996.

A simulação será feita inicialmente com o valor médio da cama de frango ( $R \$ 56,60 /$ ton) e posteriormente com os valores $R \$ 44,93$ e $R \$ 33,26 /$ ton, que representam respectivamente o valor médio menos um(1) e dois(2) desvios padrões. A simulação será feita também com os valores $R \$ 68,27$ e $R \$ 79,94 /$ ton de cama de frango, que representam respectivamente o valor médio mais um(1) e dois(2) desvios padrões. Finalmente, será feita a simulação considerando o valor da cama de frango como nulo. Com este procedimento será possível verificar, se o valor que o produtor recebe pela engorda dos frangos, cobre os custos e gera retorno positivo ao investimento, dada uma variação no valor da cama.

O Fundo de Galpão 9 é o valor depositado pela empresa ao final de cada lote produzido, em uma conta especial, denominada conta "Galpão". A quota deste fundo valia em fevereiro de 1996, R\$ 0,2247 por $\mathrm{m}^{2}$ de área construida em galpão. Este fundo é utilizado exclusivamente para a reposição de equipamentos, reformas e/ou ampliação do galpão. Para a retirada deste fundo é feita uma avaliação pela empresa juntamente com o supervisor e a associação dos produtores.

O valor residual é uma fonte de receita computada apenas no último ano de vida útil do projeto. Com base no trabalho de Lopes (1992), que analisou o mesmo tipo de investimento, estará se considerando que o período de vida útil das instalações e equipamentos é de 25 e 15 anos, respectivamente. Desta forma, considera-se que o projeto irá desenvolver-se durante 15 anos.

Utilizando-se então o método de depreciação linear, apresentado por Noronha (1987), e assumindo-se que o valor residual da sucata de equipamentos no final de 15 anos será zero, o valor residual computado no fluxo de caixa, refere-se ao restante de vida útil do galpão, que para efeito de cálculo será de 10 anos.

\footnotetext{
${ }^{9}$ Cabe ressaltar que o Fundo de Galpão é uma variável encontrada somente no contrato D.
} 
As despesas representam os gastos na construção do galpão, que são consideradas despesas fixas, e as despesas operacionais, que são variáveis. A despesa com investimento foi baseada nos gastos necessários para a construção de um galpão para engorda dos frangos com $1200 \mathrm{~m}^{2}$ (ver Apêndice3) podendo alojar até 14000 aves, bem como os equipamentos necessários para colocá-lo em funcionamento. A escolha deste galpão padrão baseia-se no trabalho de Lopes (1992), que considera ser este um tamanho mínimo que otimiza o uso da mão-de-obra de manejo, além de ser, para algumas empresas, um dos critérios de entrada do produtor na atividade.

Apesar da análise estar sendo feita para diferentes regiões do Estado de Minas Gerais, está-se assumindo que as despesas com investimento e operacionais são as mesmas em toda a área de abrangência do estudo.

Os dados referentes ao valor do investimento e despesas operacionais foram concedidos pela associação de produtores, e para efeito de cálculo, todos os valores foram deflacionados pelo IGP-DI da Revista Conjuntura Econômica, colocandose como base o mês de fevereiro de 1996.

Como despesas operacionais foram considerados os seguintes itens: mãode-obra permanente mais encargos sociais, conservação de equipamentos e galpão, material para formação da cama, mão-de-obra para apanha do frango e limpeza, gás, energia elétrica, medicamentos para desinfeção, despesa com associação e alimentação do pessoal de apanha.

Para despesas anuais com conservação do galpão e equipamentos foram considerados 2 e $5 \%$ do valor do investimento, respectivamente (baseado em Lopes, 1992).

Pressupondo que as empresas trabalham no mesmo patamar tecnológico, ou seja, que não existam diferenças significativas na qualidade dos insumos fornecidos aos produtores, pode-se considerar que, em termos médios, os resultados técnicos alcançados pelos produtores das diferentes empresas não são também significativamente diferentes. 
Levando-se este pressuposto em consideração, optou-se por analisar o impacto das diferentes fórmulas de remuneração sobre a rentabilidade do investimento submetendo o resultado alcançado pelos produtores do contrato $\mathrm{D}$ às diferentes fórmulas de remuneração. Isto será feito, porque os dados obtidos para o contrato D são observações individuais dos coeficientes técnicos de todos os produtores da empresa, no período de fevereiro de 1995 a fevereiro de 1996. Para os demais contratos, além de não ter sido possível esta série de dados, os que foram concedidos, são os resultados médios de todos os produtores, não sendo possivel desta forma, avaliar diferenças entre os produtores. Com exceção da variável preço, cotado pela APA, todos os demais dados são primários e foram coletados diretamente com as empresas, associações de produtores, Associação dos Avicultores de Minas Gerais (AVIMIG) e Instituto Mineiro de Agropecuária (IMA).

\section{4 - Custo médio ponderado do capital (CMPC)}

Como o trabalho abrange basicamente très regiões do Estado de Minas Gerais, isto é,'a região Centro, Triângulo Mineiro e Zona da Mata e considerando as características dos produtores de cada uma delas, optou-se por trabalhar com três valores de custo médio ponderado do capital.

Para a região do Triângulo Mineiro, de acordo com uma das empresas, os produtores que entram hoje na atividade têm conseguido financiar $70 \%$ dos gastos em investimento, utilizando desta forma, $30 \%$ de recursos próprios. Para a região da Zona da Mata, em pesquisa realizada por Alves Filho (1994), com uma amostra representativa dos produtores integrados, detectou-se que os produtores investiam com recursos próprios. Para a região Centro, um dos principais pólos avicolas do Estado, a informação obtida é de que existem produtores que fazem financiamento, dependendo para isto do tamanho da capacidade produtiva. Como os produtores integrados desta região foram anteriormente produtores independentes, optou-se por calcular o custo médio ponderado do capital com $50 \%$ de recursos próprios e $50 \%$ de recursos de terceiros. 
Para cálculo do custo real do capital próprio, tomou-se por base, o rendimento real da caderneta de poupança que é de $6 \%$ ao ano. No caso de recursos de terceiros, o custo real foi calculado com base na taxa de juros cobrada pela agência financiadora de $17 \%$ ao ano.

Tem-se, desta forma, os seguintes custos médios ponderados do capital:

$1^{\circ}$ caso : $\mathrm{K}=0,06(0,3)+0,17(0,7)$ ou $13,7 \%$ ao ano

$2^{\circ}$ caso : $\mathrm{K}=0,06(1,0)$ ou $6 \%$ ao ano

$3^{\circ}$ caso : $K=0,06(0,5)+0,17(0,5)$ ou $11,50 \%$ ao ano

Os valores calculados para $\mathrm{K}$, representam a taxa de atratividade minima para estimular os produtores a investirem na atividade. Cabe, no entanto, ressaitar que estes cálculos foram feitos apenas para servir de paràmetro de comparação com a taxa interna de retorno encontrada, podendo dentro de cada região e para cada produtor, o custo médio ponderado do capital mudar de forma substancial.

\section{5 - O Processo de simulação}

Tendo em vista as características do processo de produção, analisadas anteriormente, considerou-se que a única variável do fluxo de caixa que gera incerteza e que, dependendo do contrato, fornece uma determinada taxa interna de retorno, é o valor recebido pelo produtor pela engorda do frango. Este valor, reflete as variáveis técnicas utilizadas nas fórmulas de remuneração e são as seguintes.

Contrato A: conversão alimentar, peso médio e preço do $\mathrm{kg}$ de frango vivo cotado peia associação paulista de avicultura (APA);

Contrato B: peso médio, mortalidade, conversão alimentar, idade e preço do $\mathrm{kg}$ de frango vivo cotado pela associação paulista de avicultura (APA);

Contrato C: ganho de peso diário, mortalidade e conversão alịmentar;

Contrato D: mortalidade, conversão alimentar, ganho de peso diário, tempo de carregamento dos caminhões de frangos, contusão e manejo.

A partir das informações obtidas sobre estas variáveis para 428 produtores submetidos ao contrato $\mathrm{D}$, pôde-se perceber como os coeficientes técnicos variam na 
produção de um lote para outro para um mesmo produtor, como também entre os produtores. De posse destas informações, e tendo verificado a grande dependência entre as variáveis técnicas (expressões 1, 2, 3 e 4 no item 2.1.1), percebeu-se que o processo de simulação não poderia ser conduzido para cada uma destas variáveis como se elas fossem independentes. Isto poderia gerar combinação de valores incompativeis com o observado na realidade. Para solucionar este problema, resolveu-se inicialmente calcular os indices utilizados em cada contrato, uma vez que os mesmos refletem a combinação das variáveis técnicas.

No caso do contrato $\mathrm{A}$, como foi visto anteriormente (item 2.1.1), não existe uma fórmula específica, e sim uma tabela em que se combinam peso médio e conversão alimentar (ver tabela na página 97). Desta forma, as duas variáveis foram utilizadas simultaneamente no processo de simulação, ou seja, o programa foi feito para gerar inicialmente o valor de peso médio e posteriormente o valor de uma conversão alimentar compatível com o peso médio gerado de acordo com a tabela.

Para o contrato B, foi calculado o Índice de Eficiência e Produtividade (IEP), definido anteriormente pela expressão (7). Simulou-se desta forma, o IEP, ao invés de cada variável técnica.

Para o contrato C, calculou-se o Fator de Produtividade (FP), dado pela expressão (9). Esta variável é que foi usada na simulação.

No Caso do contrato $\mathrm{D}$, a simulação foi feita com a variável pontuação (P). O valor da pontuação alcançado por cada produtor, em cada lote de frango produzido, jả foi fornecido calculado.

Como o primeiro passo no método de simulação de Monte Carlo, após a definição das variáveis é a identificação do formato da distribuição, procedeu-se o teste estatístico de Kolmogorov (SAS,1990), para verificar se os dados vinham de uma distribuição normal.

Cada uma das variáveis, peso médio e conversão alimentar (contrato A), indice de eficiência e produtividade (contrato $\mathrm{B}$ ), fator de produtividade (contrato $\mathrm{C}$ ) $\mathrm{e}$ pontuação (contrato $\mathrm{D}$ ) foram submetidas ao teste, com a seguinte hipótese de nulidade: 
$\mathrm{H}_{0}$ : os dados vêm de uma distribuição normal; contra a hipótese aiternativa:

$\mathrm{H}_{\mathrm{A}}$ : os dados não vêm de uma distribuição normal.

$\mathrm{O}$ resultado do teste encontra-se no apêndice 5. Apenas para a variável peso médio, o teste mostrou-se não-significativo a $5 \%$, ou seja, não se rejeita, ao nivel de $5 \%$ de significância, a hipótese de que a variável peso médio tem distribuição normal. Para as demais variáveis, mesmo não se podendo através do teste estatístico estabelecer que elas vêm de uma distribuição normal, isto será admitido baseado no Teorema do Limite Central. Este Teorema, segundo Hoffmann (1991), diz que, se as variáveis aleatórias são independentes com média $\mu$ e variância $\sigma^{2}$ e se $\mu$ e $\sigma^{2}$ são valores finitos, a distribuição tende a ser normal, à medida que o número de observação cresce.

Para melhor visualizar a distribuição, apresenta-se nas figuras $4 \mathrm{a}, 4 \mathrm{~b}, 4 \mathrm{c}$, $4 \mathrm{~d}$ e $4 \mathrm{e}$, as distribuições de freqüência e distribuições de freqüência acumulada para as variáveis peso médio, conversão alimentar, IEP, FP e pontuação, respectivamente.

Como o programa Microsoft Excel 5.0, já fornece a inversa da distribuição normal, indispensável no processo de simulação, foi necessário apenas fornecer o valor da média e do desvio padrão de cada variável a ser simulada.

Considerando que no conjunto das observações verificam-se diferenças entre os dados de cada produtor ${ }^{10}$, ou seja, que o coeficiente técnico para o mesmo avicultor, variou na produção de um lote para o outro e, que também, existem diferenças entre os avicultores, procedeu-se a análise da variância para determinar qual o desvio padrão a ser utilizado na simulação.

Considerando cada produtor como um bloco (obteve-se então 428 blocos com um total de 2477 observações), foi feito o teste estatístico $\mathrm{F}^{11}$, tomando cada uma

\footnotetext{
${ }^{10}$ Como os dados foram coletados para o periodo de fevereiro de 1995 a fevereiro de 1996. tem-se um ciclo completo de seis lotes de frangos produzidos para a maioria dos produtores. Do total de 2568 observações possiveis, obteve-se 2477 entre os produtores estudados. Este número inferior de observações obtidas deve-se ao fato de alguns produtores terem entrado no sistema de integração durante este período.

"Para maiores detalhes sobre teste estatístico F para análise de variância ver. HOFFMANN. R.

Estatistica para economistas. São Paulo, Livraria Pioneira Editora. 1991. p. 254-255.
} 
das variáveis a ser simulada como variável dependente com o objetivo de testar ao nível de significância de $5 \%$, a seguinte hipótese de nulidade:

$\mathrm{H}_{0}$ : os efeitos de blocos são todos nulos; $\mathrm{H}_{\mathrm{A} \text { : }}$ os efeitos de blocos não são todos nulos.

Em outras palavras, o que se está testando é, se existem diferenças entre os produtores em relação à variável dependente.

Os resultados da análise de variância, encontram-se no apêndice 6. Como para todas as variáveis o teste foi significativo a $5 \%$, deve-se rejeitar a este nivel de significância, a hipótese de que o efeitos de blocos são todos nulos. Isto é, rejeita-se a hipótese de que não há diferença entre os produtores. Desta forma, a variância a ser utilizada na simulação, deverá ser a variância residual.

Para a variável preço do quilo de frango vivo cotado pela Associação Paulista de Avicultores (APA), não foi possivel proceder a nenhum teste estatístico. Como a série de dados aparentemente apresentava uma distribuição retangular e todos os parâmetros desta distribuição foram facilmente observados na série de dados, assumiu-se que eles apresentam-se na forma de uma distribuição retangular. $\mathrm{Na}$ figura $4 \mathrm{f}$ tem-se a distribuição de frequêencia e distribuição de freqüência acumulada da variável para preço do frango. No apêndice 4 , apresenta-se a representação gráfica e a expressão geral para a função de distribuição de probabilidade do tipo retangular. 


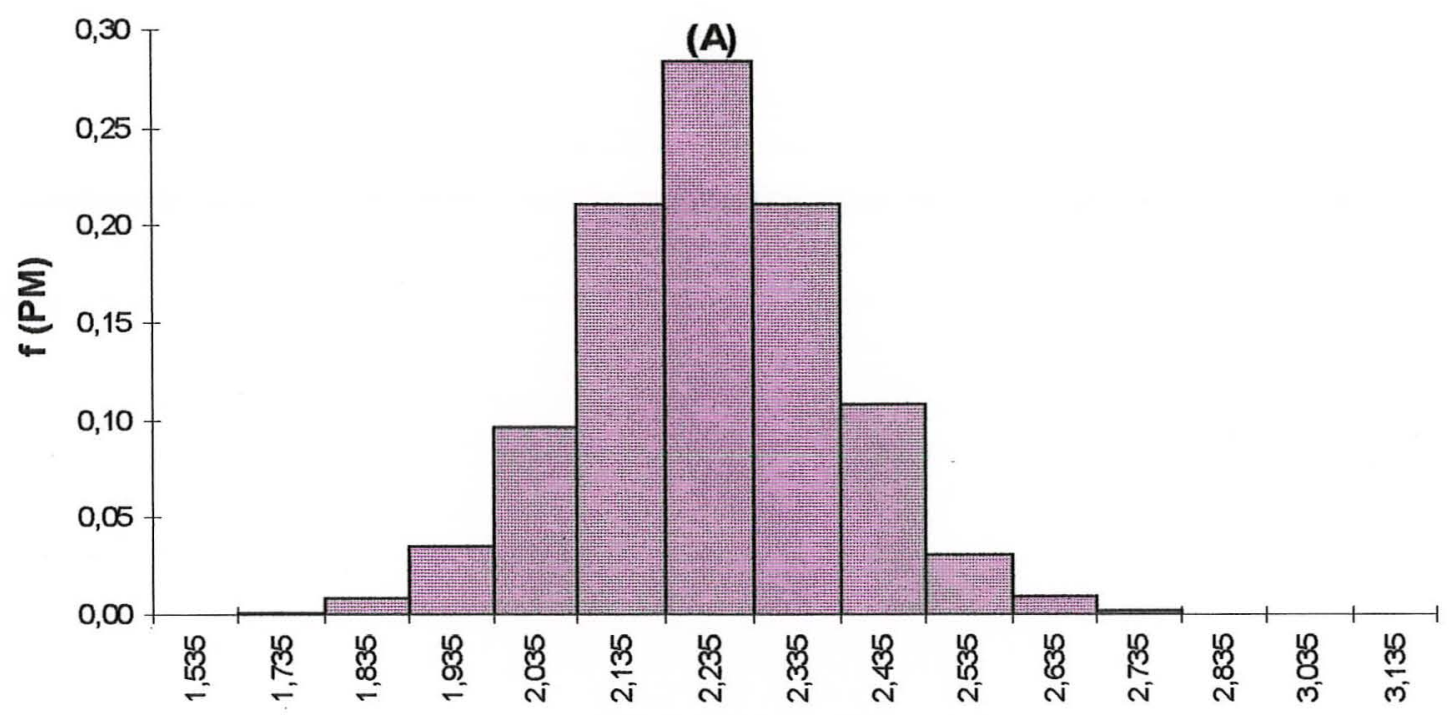

Peso Médio - PM ( em Kg)

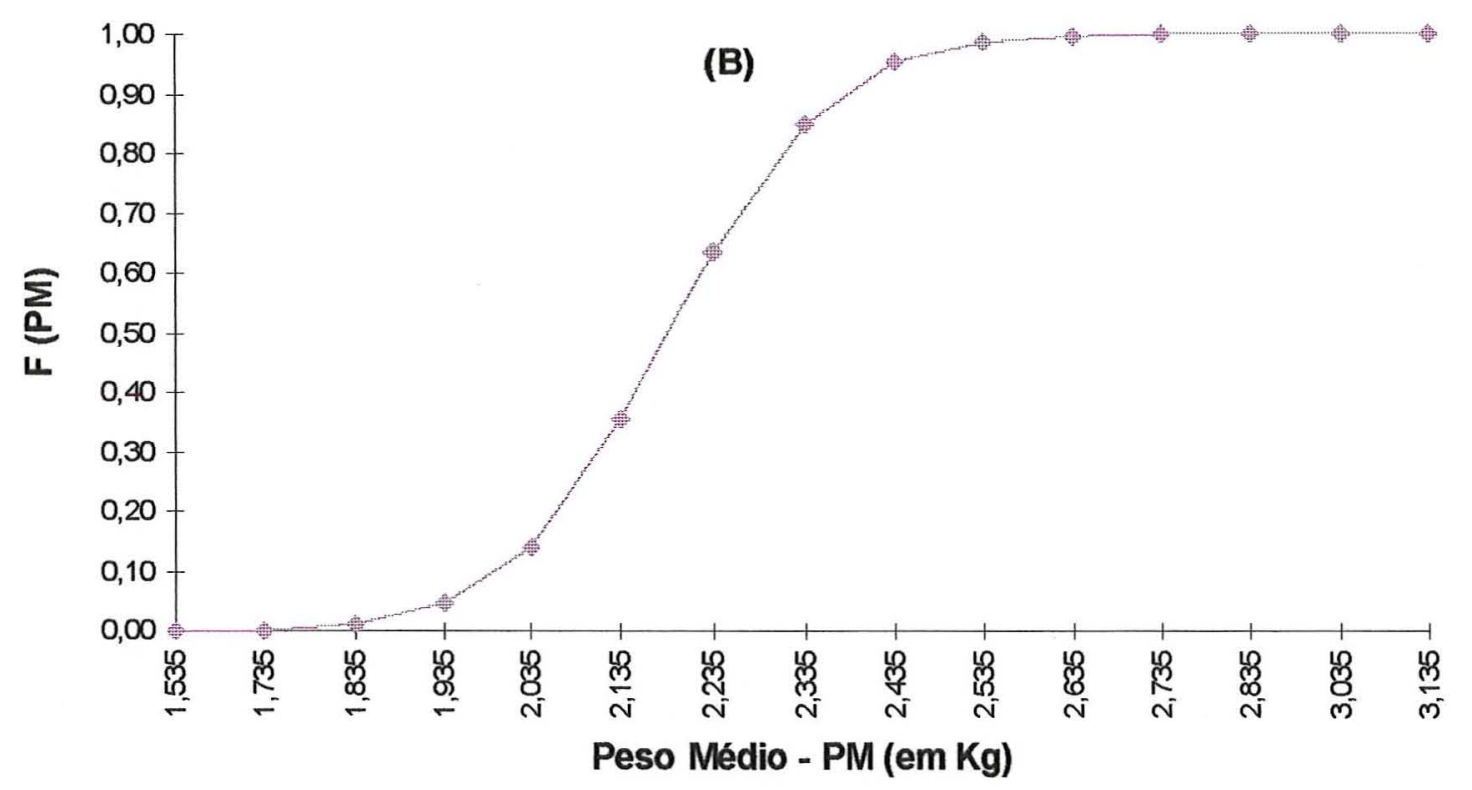

Fonte: Dados da Pesquisa

FIGURA 4a - (A) Distribuição de Freqüência e (B) Distribuição de Freqüência Acumulada para Peso Médio (PM), caso Contrato A.

Média $=2,19$

Desvio Padrão $=0,145$ 

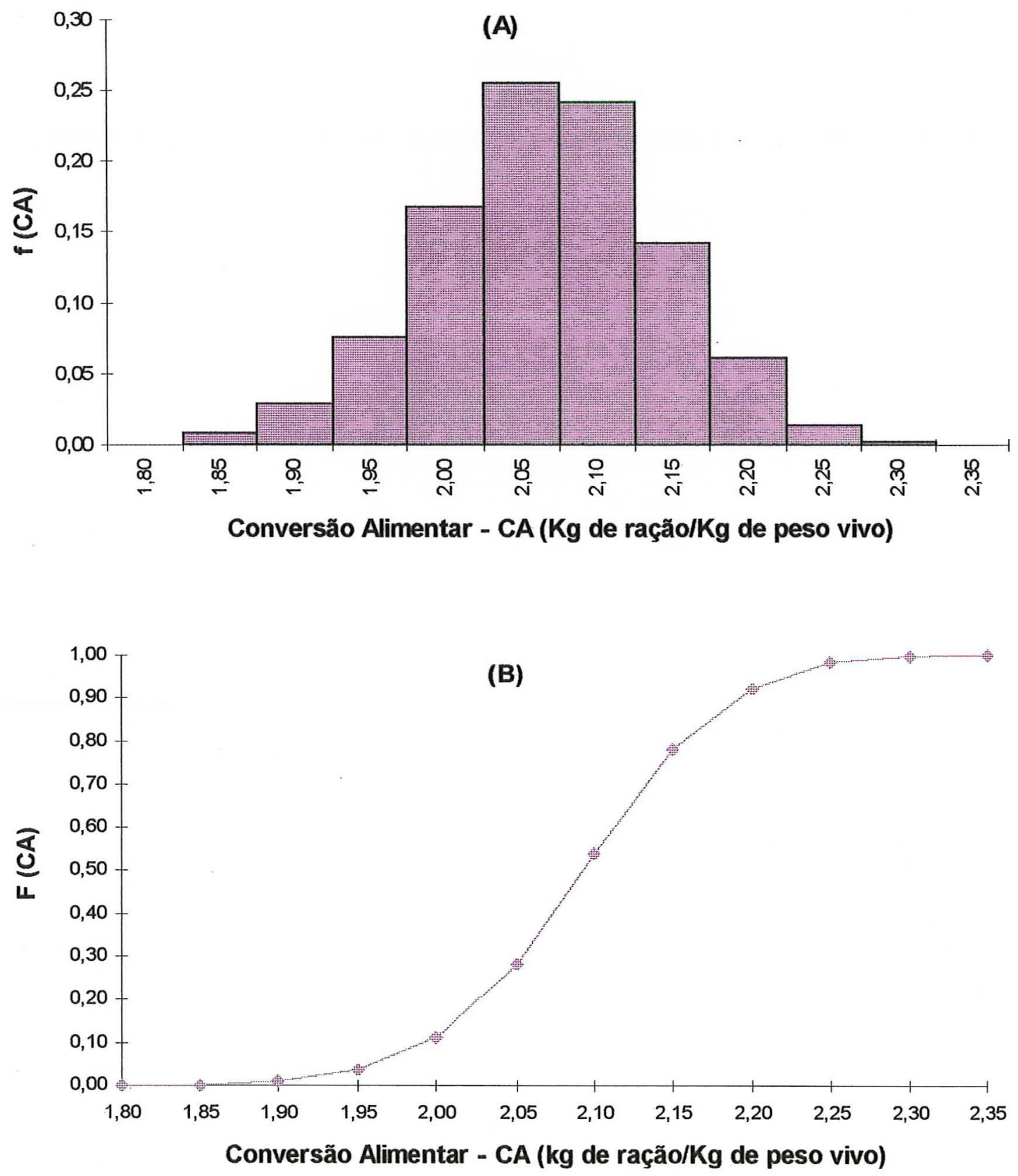

Fonte: Dados da Pesquisa

FIGURA 4b - (A) Distribuição de Freqüência e (B) Distribuição de Freqüência Acumulada para Conversão Alimentar - CA, caso Contrato A.

Média $=2,05$

Desvio Padrão $=0,054$ 

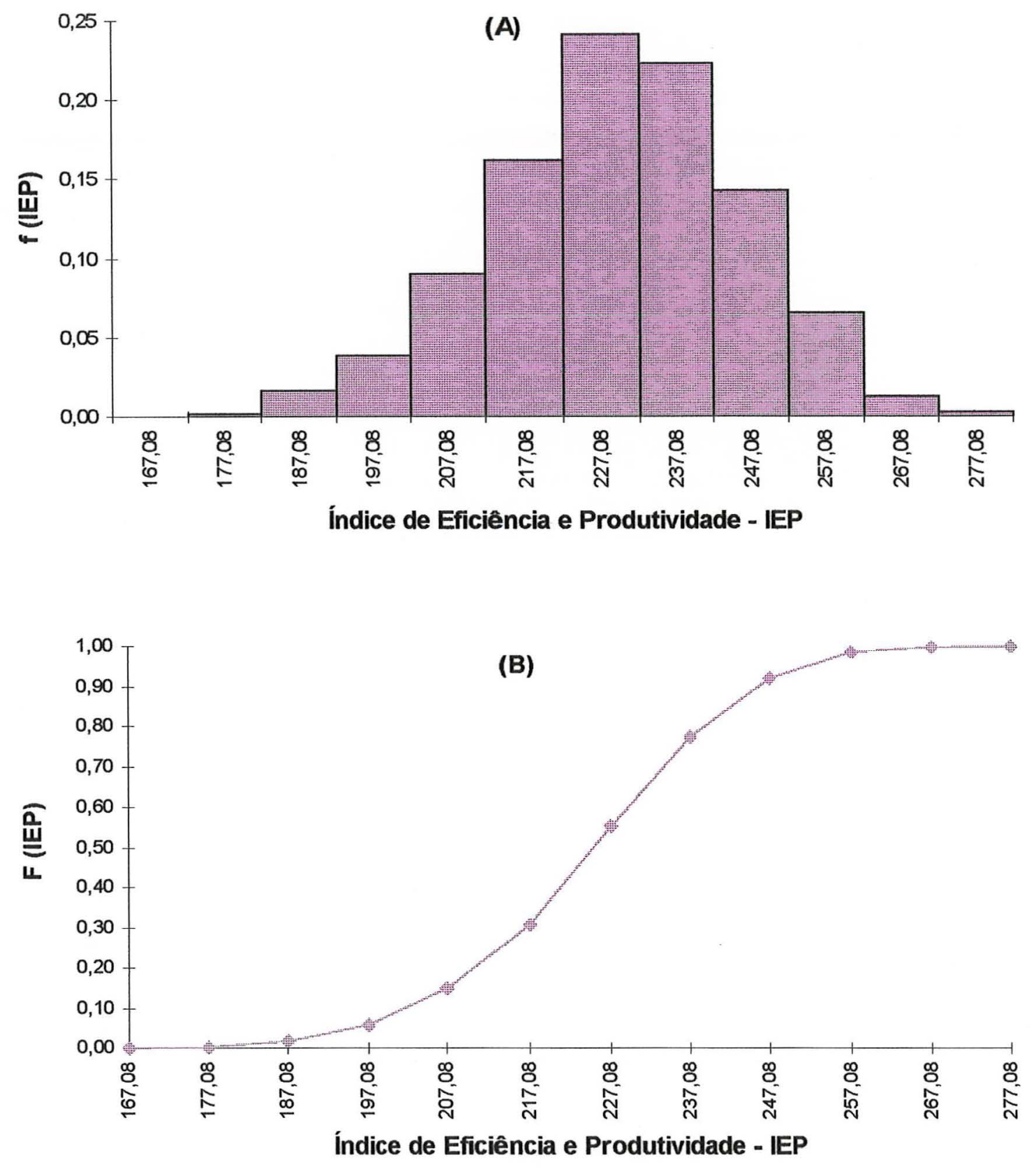

Fonte: Dados da Pesquisa

FIGURA 4c - (A) Distribuição de Freqüência e (B) Distribuição de Freqüência Acumulada para Índice de Eficiência e Produtividade - IEP, caso Contrato B.

Média $=224,37$

Desvio Padrão $=15,92$ 

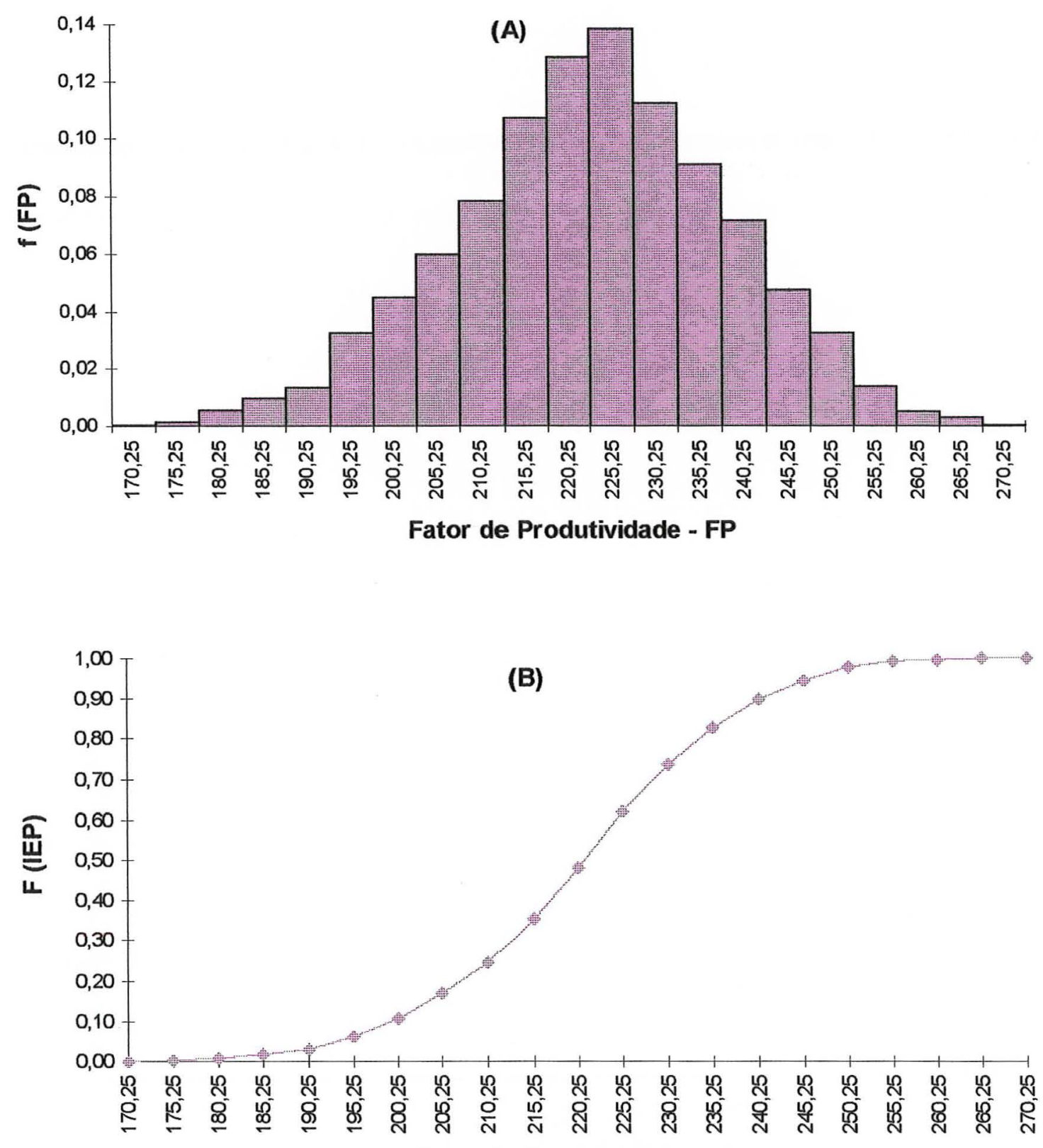

Fator de Produtividade - FP

Fonte: Dados da Pesquisa

FIGURA 4d - (A) Distribuição de Freqüência e (B) Distribuição de Freqüência Acumulada para Fator de Produtividade - FP, caso Contrato C.

Média $=220,44$

Desvio Padrão $=15,07$ 

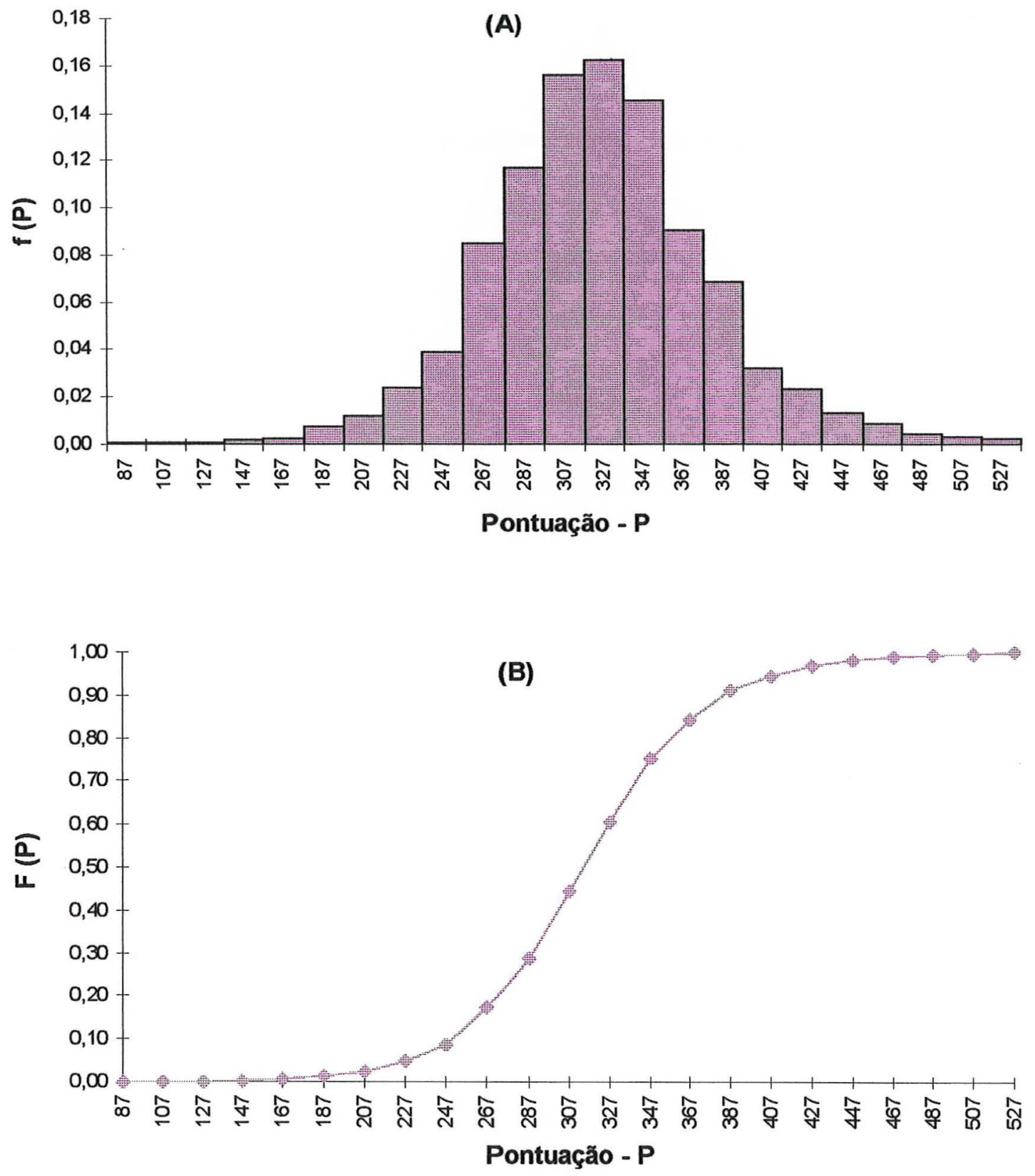

Fonte: Dados da Pesquisa

FIGURA 4e - (A) Distribuição de Freqüência e (B) Distribuição de Freqüência Acumulada para Pontuação - P, caso Contrato D.

Média $=315,65$

Desvio Padrão $=53,26$ 

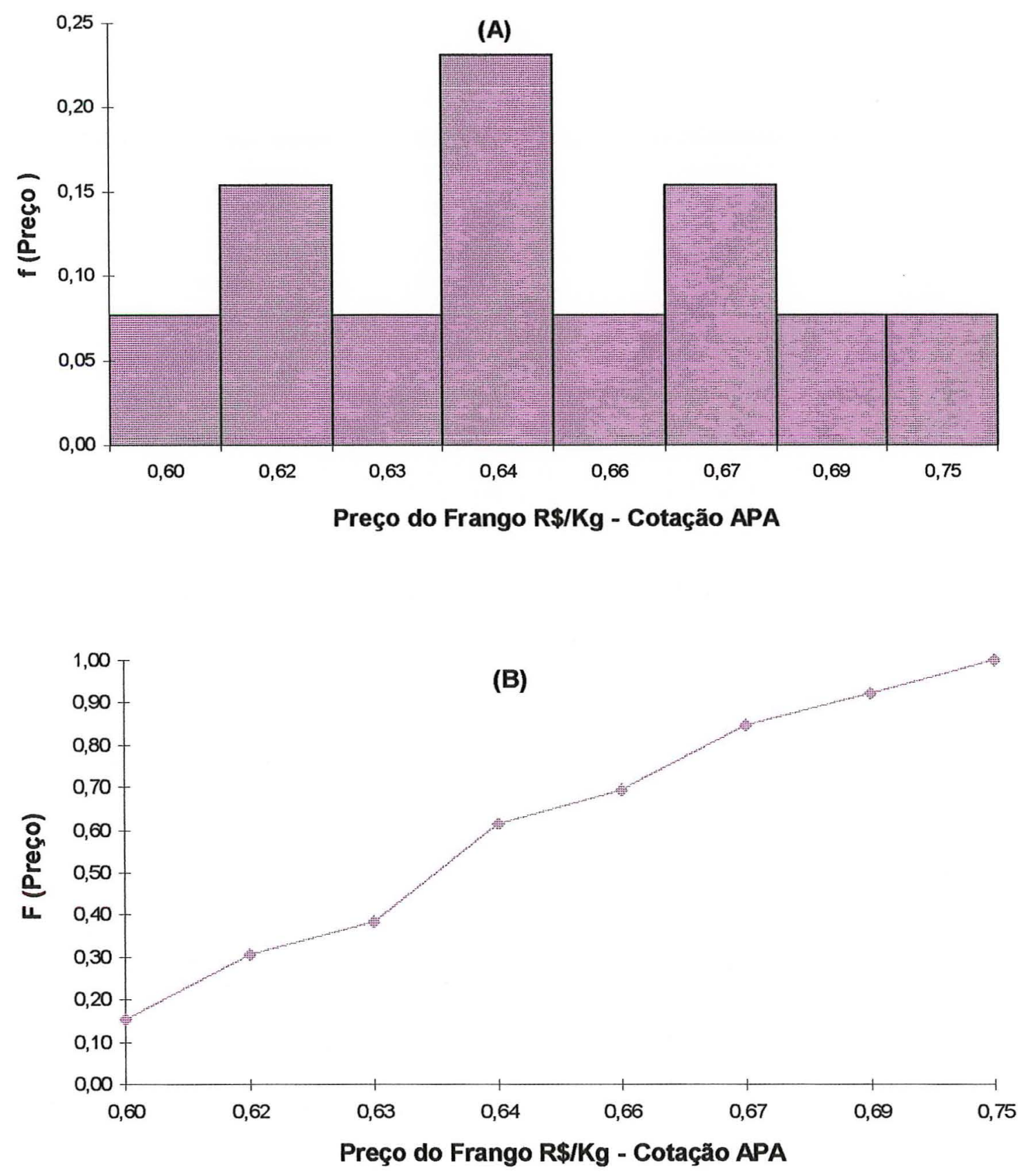

FONTE: AVES \& OVOS, APA, (12) 5, mar. 1996.

FIGURA 4f - (A) Distribuição de Freqüência e (B) Distribuição de Freqüência Acumulada para Preço de Frango (Preço Médio de Frango Vivo), cotação APA. Valor real deflacionado pelo IGP - DI da Fundação Getúlio Vargas, base fev. $1996=100$. 
Definidas então as distribuições de probabilidade, o método de simulação foi aplicado a todas as variáveis, tendo-se feito um programa específico para cada contrato. Para todos os contratos foi seguida basicamente a seguinte rotina: simulou-se oitenta e nove ${ }^{12}$ (89) lotes de frango para se calcular uma taxa interna de retorno. A cada simulação o programa calculava o valor a ser recebido por aquele lote e armazenava adequadamente este resultado, até que se completassem seis (6) simulações. $O$ resultado alcançado, que representava um ano, era então colocado no fluxo de caixa. Este processo era repetido para os quinze (15) anos, para finalmente ser calculada uma taxa interna de retorno (TIR).

O processo foi repetido 38.092 vezes, gerando 428 taxas internas de retorno. Noronha (1987) sugere que 300 taxas internas de retorno é um número satisfatório para a análise de incerteza nos projetos de investimentos.

Este método de simulação nada mais é do que a elaboração de um grande número de projetos semelhantes, capaz de fornecer a taxa interna de retorno a partir da sua função de distribuição de probabilidade. Os resultados serão apresentados na forma tabular, em intervalos de classe, para cada contrato, tornando possível analisar com qual probabilidade determinada taxa interna de retorno será alcançada.

Comparando-se os resultados da simulação com o custo médio ponderado do capital (CMPC) será possível fornecer, dadas as caracteristicas de cada contrato, o risco do investimento e as possibilidades de retorno.

\footnotetext{
${ }^{12} \mathrm{O}$ número 89 foi encontrado multiplicando-se seis lotes de frango por quatorze anos mais cinco lotes referentes ao ano 1. Considerou-se neste caso, dois (2) meses do ano 1 como necessários para a construçăo do galpão, sendo possível desta forma a criação de apenas cinco (5) lotes.
} 


\section{CAPÍTULO III- RESULTADOS E DISCUSSÕES}

\section{1- A produção sob contratos de integração vertical no Estado de Minas Gerais - evolução e distribuição geográfica.}

Neste item, serão apresentados os resultados da pesquisa, no que se refere aos órgãos representativos do setor avícola mineiro, evolução da produção sob contratos de integração vertical, bem como, a sua distribuição geográfica.

Inicialmente foi visitada a Associação dos Avicultores de Minas Gerais (AVIMIG), uma entidade respeitada pela sociedade e principal órgão representativo do setor avicola do Estado. A associação foi fundada em 1955, com sede em Belo Horizonte, e tem como objetivo principal representar os associados junto ao governo, bem como mantê-los informados da realidade avícola. A associação contava em outubro de 1995, com cerca de 300 associados, incluindo produtores independentes, cooperativa de produtores, abatedouros e empresas integradoras.

Funciona também junto à sede da associação, a Bolsa de Frango. Ela foi fundada em 1972, com o objetivo de fazer a cotação do preço do frango vivo que refletisse a realidade do mercado. A reunião da Bolsa de Frango ocorre uma vez por semana e, após discutir com a diretoria e também assistir a uma delas, percebeu-se o seguinte procedimento: os associados presentes, discutem de inicio, aleatoriamente com o presidente, a situação de oferta e procura, que consiste em alguns dos presentes indicarem se têm previsão de maior ou menor quantidade de aves a ser comercializada com relação à semana anterior. A partir desta rápida alusão à oferta, o presidente escolhe uma comissão com oito (8) membros, sendo quatro (4) produtores de frango e quatro (4) 
compradores, com o objetivo de propor o preço para o quilo de frango vivo. A votação é feita logo em seguida, votando o presidente só em caso de empate. A cotação é feita também para o quilo do frango abatido, cama de frango e ovos. Este preço é divulgado diariamente pela associação de produtores, tendo como objetivo servir de parâmetro para as negociações feitas naquela semana.

Dado o número de associados, percebeu-se uma fraca participação ao pregão. Segundo o presidente, a participação depende muito da situação do mercado. A maior freqüência é percebida quando existe uma tendência do mercado a comportar-se como comprador.

Apesar do interesse dos produtores predominar pela comercialização de frangos vivos, na opinião do presidente da associação, que é também o presidente da bolsa, a produção de frango de corte mineira está caminhando a passos largos para a integração vertical sob contratos.

Além de uma publicação mensal "Atualidade Avícola", a associação fornece aos seus membros, a cotação diária do preço de frango vivo, abatido, cama de frango e ovos, através de um serviço telefônico que funciona 24 horas.

Foi visitado também, o Instituto Mineiro de Agropecuária (IMA), sendo possivel obter informações desagregadas sobre a produção do Estado, além de ter-se tomado conhecimento do Programa de Sanidade Avícola, desenvolvido por este instituto. O objetivo principal do programa é cadastrar avozeiros, matrizeiros, incubatórios, produtores de frango de corte e postura, com o intuito de controlar o sistema de vacinação, com o objetivo de manter o plantel mineiro dentro das normas sanitárias.

A produção de frango de corte do Estado de Minas Gerais, desenvolveuse de forma bem distinta dos principais Estados produtores. Até 1980, a avicultura de corte mineira caracterizou-se por uma produção independente e altamente pulverizada. Houve uma reorganização neste setor e atualmente a produção de frango de corte do Estado pode ser subdividida basicamente em três modalidades diferentes de conduta de produção:

- produtores independentes; 
- produtores cooperados; e

- produtores submetidos ao sistema de integração sob contratos.

Os produtores independentes como o próprio nome diz, não têm necessariamente vínculo de compra de insumos ou venda do produto com nenhuma empresa. Estes avicultores compram a ração pronta ou adquirem o milho, farelo de soja, concentrado e outros ingredientes e formulam a ração na própria propriedade. Os pintos de um dia são também adquiridos no mercado aberto, podendo mudar com freqüência de fornecedor. De um modo geral, estes produtores recebem assistência técnica da EMATER/MG, técnicos autônomos e empresas ligadas aos segmentos de ração, pintinhos, medicamentos e equipamentos.

Por produtores cooperados, entende-se a reunião de um número de avicultores em torno de uma cooperativa, com o intuito de comprarem conjuntamente os insumos básicos à produção de frango, bem como a industrialização e comercialização do produto final. Neste sistema, os associados comprometem-se a adquirir os insumos da cooperativa e entregar a produção (frangos de corte) à mesma. Para os associados que desejam pagar os insumos a prazo é cobrada uma taxa de juro que não diferencia muito da praticada no mercado. De acordo com o dirigente da cooperativa entrevistada, "o cooperado corre o risco de ganhar ou perder, conforme o preço de mercado do frango vivo na semana de saída das aves". O preço pago aos cooperados é estabelecido pela média de preços da semana.

O avanço da produção integrada sob contratos em Minas Gerais, por outro lado deu-se fundamentalmente pela reorganização do setor, ou seja, existe uma tendência de mercado para que este caminho seja seguido. Na tabela 1, tem-se a distribuição dos produtores de frango de corte do Estado entre independentes/cooperados e integrados contratualmente, além da localização geográfica e, pela figura 5 , a distribuição geográfica dos produtores integrados.

De acordo com o IMA, o cadastramento dos produtores de frango de corte, feito em 1995, abrangeu mais de $95 \%$ do total de produtores. No caso dos 
produtores integrados, o levantamento feito diretamente com as empresas é coerente com o cadastramento feito pelo IMA.

Tabela 1 - Distribuição regional dos produtores de frango de corte independentes/ cooperados e integrados contratualmente / Minas Gerais - 1986/1995.

\begin{tabular}{|c|c|c|c|c|c|}
\hline \multirow[t]{2}{*}{$\overline{R E G I A ̃ O}$} & \multirow[t]{2}{*}{$\begin{array}{c}\text { DELEGACIAS REGIONAIS } \\
\text { DO IMA }\end{array}$} & \multicolumn{2}{|c|}{$\begin{array}{c}\text { PRODUTORES } \\
\text { INDEPENDENTES* }\end{array}$} & \multicolumn{2}{|c|}{$\begin{array}{l}\text { PRODUTORES } \\
\text { INTEGRADOS }\end{array}$} \\
\hline & & $1986^{1}$ & $1995^{2}$ & $1986^{1}$ & $1995^{3}$ \\
\hline Centro & $\begin{array}{c}\text { Bambuí, Belo Horizonte e } \\
\text { Curvelo }\end{array}$ & 434 & 201 & 18 & 77 \\
\hline Zona da Mata & Juiz de Fora e Ponte Nova & 108 & 94 & 242 & $\mathbf{4 5 5}$ \\
\hline Triângulo Mineiro & $\begin{array}{c}\text { Patrocínio, Uberaba e } \\
\text { Uberlândia }\end{array}$ & 72 & 54 & 27 & 362 \\
\hline Sul & $\begin{array}{l}\text { Oliveira, Passos e São } \\
\text { Gonçalo do Sapucaí }\end{array}$ & 187 & 86 & 7 & 41 \\
\hline $\begin{array}{l}\text { Norte } \\
\text { Nordeste }\end{array}$ & $\begin{array}{c}\text { Montes Claros } \\
\text { Governador Valadares e } \\
\text { Teófilo Otoni }\end{array}$ & $\begin{array}{l}21 \\
85\end{array}$ & $\begin{array}{c}1 \\
30\end{array}$ & $\begin{array}{l}2 \\
2\end{array}$ & - \\
\hline TOTAL & & 907 & 466 & 298 & 925 \\
\hline
\end{tabular}

* Inclui produtores cooperados.

Fonte: ${ }^{1}$ - FERNANDES, E. A ; PINTO, M. O . Avicultura em Minas Gerais. Belo Horizonte, EMATER, 1988. 16p.

2 - Levantamento feito pelo Instituto Mineiro de Agropecuária (IMA).

3 - Dados da Pesquisa

Pela tabela 1, percebe-se claramente a queda no número de produtores independentes/cooperados e um aumento significativo de produtores integrados. Parte da queda do número de produtores independentes da região Centro é explicada pelo número de produtores integrados. No período analisado, três empresas passaram a atuar com este sistema de produção, integrando produtores que anteriormente eram independentes ou cooperados. 
Os 466 produtores independentes e ou cooperados cadastrados pelo IMA, tinham na época da pesquisa 22,739 milhões de frangos alojados, com uma capacidade média por produtor em torno de 48.796 aves. Os 925 produtores integrados por outro lado, têm uma capacidade média de alojamento de 12,797 milhões de aves, sendo uma média por produtor em torno de 13.834 aves.

De acordo com Sorj et al. (1982), a produção avícola mineira mostrou-se sempre instável em termos de números de produtores, existindo uma grande entrada de novos produtores, mas também sendo alta a saída de outros. Em 1978, o parque avícola mineiro de corte tinha aproximadamente 1.209 produtores, passando para $2.094 \mathrm{em} 1980$ e, 1.205 em 1986, mantendo-se quase no mesmo patamar em 1995, com cerca de 1.374 produtores.

A região Centro é onde se localiza o mais antigo pólo avícola do Estado com uma predominância de produtores independentes e cooperados. Até 1990, em pesquisa realizada por Alves Filho (1994), a produção de frango de corte sob integração contratual não era muito aceita na região. Percebeu-se uma forte restrição a este sistema, uma vez que para os produtores independentes ele representava perda de liberdade e autonomia. Em 1995, o quadro muda um pouco, há um crescimento do número de produtores integrados nesta região, mas ainda é pequeno, uma vez que estão integrados a apenas três empresas. No depoimento de todas três, a integração surgiu como uma opção de aproveitamento de granjas que estavam paradas. Muito provavelmente, ainda deve existir granjas ociosas, mas por restrição ao sistema, ou por esperanças de um melhor momento para produzir, alguns produtores preferem mantê-las fechadas. 


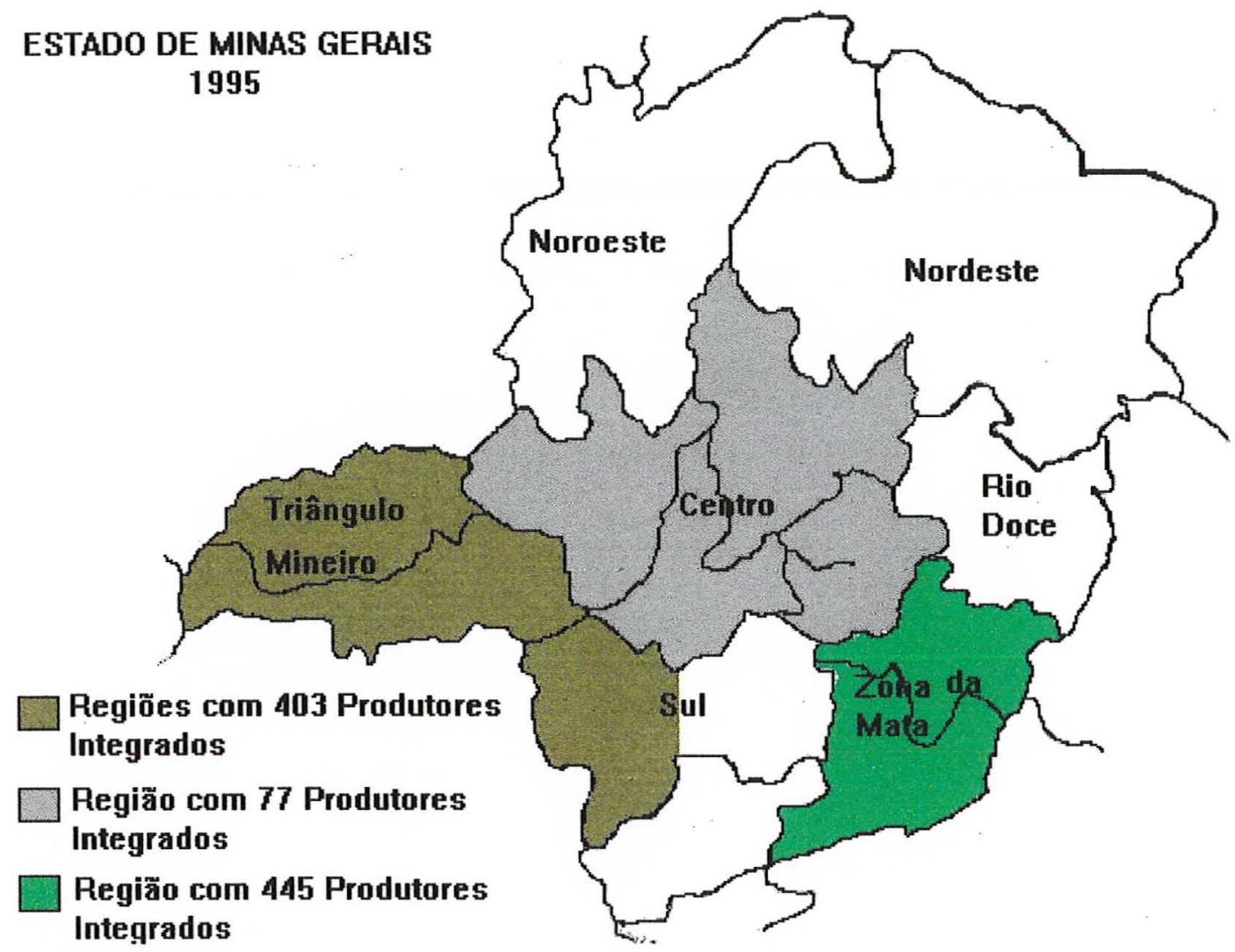

Fonte: Adaptado de Mapas fornecidos pela EMATER/MG e IMA.

FIGURA 5 - Distribuição Regional dos Produtores de Frango de Corte Integrados contratualmente/ Minas Gerais - 1995.

Percebe-se claramente o predomínio da produção integrada nas regiões da Zona da Mata e Triângulo Mineiro, cabendo ressaltar, que os produtores integrados localizados na região Sul, são avicultores contratados por empresas localizadas no Triângulo Mineiro.

Apesar da distância dos pólos produtores de soja e milho, principais insumos para o fabrico da ração avícola, a região da Zona da Mata foi a pioneira na implantação deste sistema de produção. Mesmo não se tendo conhecimento de nenhum estudo que medisse o impacto da implantação desta agroindústria na renda da região e dos produtores especificamente, a aceitação deste sistema parece ter sido satisfatória, uma vez que no período de 1986/95, a taxa média de crescimento anual de entrada de 
produtores na atividade foi de $6,28 \%$. Apenas duas empresas atuam com este sistema na região, agregando 445 produtores em torno de trinta e cinco (35) municipios.

$\mathrm{Na}$ região do Triângulo Mineiro, este sistema de produção também parece já estar bem consolidado. Esta região tem a vantagem de ser produtora de grãos, e uma das mais prósperas do Estado, no que se refere ao setor agroindustrial. Existem também duas empresas integradoras, agregando 403 produtores, distribuídos em cerca de 23 municipios. A tendência é que daqui a alguns anos, o número de produtores integrados aumente ainda mais, haja visto que uma das empresas integradoras, está em periodo de implantação do sistema, desejando ter até o final de 1996, 100 produtores integrados, com ampliações para o futuro, uma vez que, com este número de produtores apenas $25 \%$ da capacidade de abate seria preenchida.

Apesar de $67,32 \%$ dos produtores cadastrados pelo IMA estarem submetidos ao sistema de coordenação contratual, a maior parte da produção do Estado ainda é proveniente das modalidades independente e cooperada. De acordo com a AVIMIG, Minas Gerais tem uma produção mensal estimada em 19 milhões de frangos. Com esta produção o Estado deve ter no mínimo uma capacidade de alojamento em torno de 38 milhões de aves. Como será visto mais adiante, a capacidade de alojamento sob coordenação contratual gira em torno de $41,26 \%$ da capacidade produtiva do Estado.

\section{2 - Coordenação contratual}

Neste item será feita uma descrição das empresas integradoras no que se refere à capacidade produtiva, número de produtores integrados, estágios produtivos, entre outros aspectos.

O Estado de Minas Gerais conta hoje com 7 empresas que trabalham com o sistema de produção integrada sob contratos. Independente do estágio produtivo em que começaram a atuar, em algum momento, estas empresas evoluíram e algumas ainda têm espaço para evoluir tanto para estágios anteriores aos originais, como posteriores. As empresas foram numeradas de 1 a 7 , com o objetivo de preservar o sigilo quanto a 
identidade de cada uma. Pela tabela 2 , tem-se os diferentes estágios em que as empresas estão envolvidas atualmente.

Tabela 2 - Estágios produtivos em que atuam as empresas integradoras - Minas Gerais/1995.

\begin{tabular}{l|cccccccc}
\hline ESTÁGIOS DE PRODUÇ̃̃O & $\mathrm{E}$ & $\mathrm{M}$ & $\mathrm{P}$ & $\mathrm{R}$ & $\mathrm{E}$ & $\mathrm{S}$ & $\mathrm{A}$ S \\
\hline \multirow{2}{*}{ Importação de Material Genético (Avozeiros) } & $\mathrm{1}$ & 2 & 3 & 4 & 5 & 6 & 7 \\
\cline { 2 - 7 } Produção de Matriz para Corte & - & - & - & - & - & $\mathrm{X}$ & - \\
Venda de Matriz de Corte para Mercado Aberto & - & - & - & - & - & $\mathrm{X}$ & - \\
Matrizeiro & - & - & - & - & - & $\mathrm{X}$ & - \\
Incubatório (pintos de 1 dia para corte) & $\mathrm{X}$ & - & & - & - & $\mathrm{X}$ & $\mathrm{X}$ \\
Venda de pintos de 1 dia para mercado aberto & $\mathrm{X}$ & - & $\mathrm{X}$ & - & - & $\mathrm{X}$ & $\mathrm{X}$ \\
Fábrica de Ração & - & - & $\mathrm{X}$ & - & - & $\mathrm{X}$ & - \\
Produção Própria de Frango de Corte & $\mathrm{X}$ & $\mathrm{X}$ & $\mathrm{X}$ & $\mathrm{X}$ & $\mathrm{X}$ & $\mathrm{X}$ & $\mathrm{X}$ \\
Produção de frango de corte advinda de produtores & & & $\mathrm{X}$ & $\mathrm{X}$ & $\mathrm{X}$ & $\mathrm{X}$ & - & $\mathrm{X}$ \\
integrados & $\mathrm{X}$ & $\mathrm{X}$ & $\mathrm{X}$ & $\mathrm{X}$ & $\mathrm{X}$ & $\mathrm{X}$ & $\mathrm{X}$ \\
Abatedouro & $\mathrm{X}$ & $\mathrm{X}$ & $\mathrm{X}$ & - & - & $\mathrm{X}$ & $\mathrm{X}$ \\
Industrialização & $\mathrm{X}$ & - & $\mathrm{X}$ & - & - & $\mathrm{X}$ & $\mathrm{X}$ \\
Comercialização & $\mathrm{X}$ & $\mathrm{X}$ & $\mathrm{X}$ & $\mathrm{X}$ & $\mathrm{X}$ & $\mathrm{X}$ & $\mathrm{X}$ \\
\hline
\end{tabular}

Fonte: Dados da Pesquisa

Apenas a empresa 6 coordena o processo de ponta a ponta deixando a cargo dos produtores integrados toda a produção de frango de corte. A empresa possui 500 mil matrizes e um incubatório com capacidade de produzir 12 milhões de pintos de um dia por mês. Todo o excedente é vendido para o mercado interno e externo, sendo a produção de frango de corte ainda um pequeno segmento da empresa, em relação aos demais.

A empresa 3, apesar de ter a produção de frango de corte como o carro chefe, possui um excedente de produção de pintos de um dia que é comercializado no mercado aberto. A produção mensal do incubatório é de 3 milhões de pintinhos. 
As empresas 1 e 7 têm a produção de frango de corte como seus principais objetivos e toda a capacidade produtiva dos incubatórios é para suprir a demanda interna, sendo às vezes necessária a aquisição de pintinhos no mercado. A empresa 1 tem um incubatório com capacidade de produzir 1,880 milhão pintinhos por mês enquanto a empresa 7 , produz em torno de 2,520 milhões.

Das sete integradoras, cinco possuem abatedouro. Na tabela 3, tem-se a capacidade de abate, além de ser mostrado se são inspecionados pelo Serviço de Inspeção Federal - SIF.

Tabela 3 - Localização regional, capacidade de abate e inspeção federal dos abatedouros de aves pertencentes às integradoras - Minas Gerais/1995.

\begin{tabular}{l|c|c|c}
\hline \multicolumn{1}{c|}{ Região } & Empresa & Inspecionado pelo SIF & $\begin{array}{c}\text { Capacidade de Abate } \\
\text { Aves/Hora }\end{array}$ \\
\hline Centro & Empresa 3 & SIM & 4.000 \\
Zona da Mata & Empresa 2 & NÃO & 900 \\
& Empresa 7 & SIM & 4.800 \\
Triângulo Mineiro & Empresa 1 & SIM & 7.000 \\
& Empresa 6 & SIM & $20.000^{1}$ \\
\hline
\end{tabular}

Fonte: Dados da Pesquisa

1 - Paralisado com planos de iniciar funcionamento em outubro de 1996.

Apenas a empresa 2 tem abate sem inspeção federal, existindo apenas inspeção municipal.

Neste ponto, é interessante ressaltar que o Estado de Minas Gerais possui apenas 14 abatedouros avícolas com inspeção federal, com uma capacidade total instalada de abate de 59.300 aves/hora. Deste total, 60,37\% pertencem às empresas integradoras. Estes dados revelam o lado caótico do abate de frangos do Estado. Se todos os abatedouros trabalhassem com a plena capacidade, seria suficiente para abater menos de $50 \%$ da produção. Segundo a AVIMIG, existe um número muito grande de pequenos abatedouros (mais de 1000) sem nenhum tipo de inspeção e um número 
reduzido de instalações com outro tipo de inspeção (em torno de 50), seja municipal ou estadual.

Apesar das grandes diferenças existentes entre estas empresas, tanto no que se refere ao número de estágios em que atuam, quanto ao tamanho da capacidade produtiva e no número de produtores integrados, o que coloca estas empresas no mesmo nível de análise, é a relação contratual existente com os produtores.

Em todas estas empresas, existem contratos formais de produção, nos quais cabe às integradoras fornecer aos produtores pintos de um dia, ração e assistência técnica, insumos estes pertencentes às empresas, sendo o produtor um fiel depositário dos mesmos (a análise mais detalhada dos contratos será feita posteriormente). Os produtores, por outro lado, incumbem-se de fornecer galpões devidamente equipados, mão-de-obra para o manejo, material para a cama, entre outras despesas operacionais.

Independente da empresa produzir ou não algum insumo necessário à produção de frango de corte, como é o caso das empresas 2,4 e 5 , que não têm incubatório, elas adquirem os insumos no mercado aberto e os fornecem aos produtores. Neste caso os produtores não têm conhecimento da origem destes insumos. Estas empresas começaram a trabalhar com este sistema de produção muito recentemente $\mathrm{e}$ pôde-se perceber uma grande vontade de expansão, principalmente para as duas que comercializam os frangos vivos (empresas 4 e 5 ).

Foi perguntado a cada uma das empresas quais os principais motivos que as levaram a contratar produtores para a fase de engorda dos frangos. Na tabela 4 , tem-se de forma resumida as respostas obtidas. 
Tabela 4- Motivos que levaram as empresas a integrarem-se com produtores avicolas Minas Gerais/1995.

\begin{tabular}{|c|c|}
\hline & MOTIVOS \\
\hline Empresa 1 & $\begin{array}{l}\text { - origem da empresa: } \\
\text { - tendência de mercado; } \\
\text { - homogeneidade da matéria-prima, (padronização } \\
\text { das carcaças). }\end{array}$ \\
\hline Empresa 2 & $\begin{array}{l}\text { - suprir capacidade de abate da empresa; } \\
\text { - matéria-prima assegurada; } \\
\text { - matéria-prima homogênea. }\end{array}$ \\
\hline Empresa 3 & $\begin{array}{l}\text { - tendência de mercado; } \\
\text { - suprir capacidade de abate da empresa com } \\
\text { matéria-prima assegurada; } \\
\text { - muitas granjas de produtores independentes } \\
\text { paradas. }\end{array}$ \\
\hline Empresa 4 & $\begin{array}{l}\text { - aumentar a produção para garantir melhor } \\
\text { comercialização; } \\
\text { - grande número de granjas paradas na região. }\end{array}$ \\
\hline Empresa 5 & $\begin{array}{l}\text { - aumentar a produção para garantir melhor } \\
\text { comercialização; } \\
\text { - grande número de granjas paradas na região. }\end{array}$ \\
\hline Empresa 6 & $\begin{array}{l}\text { - tendência de mercado: } \\
\text { - matéria-prima homogênea: } \\
\text { - reduzir necessidade de investimento. Os gastos } \\
\text { que se teria que fazer em granjas mais despesas } \\
\text { operacionais são totalmente poupados. }\end{array}$ \\
\hline Empresa 7 & $\begin{array}{l}\text { - diminuir gastos operacionais; } \\
\text { - aumento da produtividade; } \\
\text { - este sistema tem reflexos sociais na região. }\end{array}$ \\
\hline
\end{tabular}

Fonte: Dados da Pesquisa

Parece existir um consenso quanto aos motivos que levaram as empresas a integrarem-se. Um fato interessante é que apesar de existirem empresas relativamente pequenas, ou que atuam em poucos estágios do processo produtivo, a integração contratual soluciona um problema de escala. As grandes empresas do setor avícola brasileiro são poucas e detêm uma fatia considerável do mercado. Só a título de ilustração, como foi visto no capítulo I, apenas cinco empresas detêm $68 \%$ da exportação 
de carne de frango e, todas atuam no sistema de coordenação contratual. Como neste sistema de produção as empresas livram-se de imobilizar capital na construção de granjas e gerenciamento das mesmas (no que se refere a encargos sociais e salários com granjeiros), elas podem imobilizar capital em estágios mais elaborados, diversificando e controlando de forma mais eficiente o processo produtivo.

Algumas empresas além da produção contratada, também têm produção própria. Isto ocorre porque estas empresas começaram na atividade como produtoras de frango de corte; no entanto, iniciado o processo de integração, não houve expansão destas granjas. A tabela 5 mostra a distribuição da produção e o número de produtores integrados.

Tabela 5 - Empresas integradoras - produção própria e integrada de Frango de Corte, número de produtores integrados e capacidade média de alojamento Minas Gerais/1995.

\begin{tabular}{|c|c|c|c|c|c|c|}
\hline \multirow[t]{2}{*}{ EMPRESA } & \multicolumn{2}{|c|}{\begin{tabular}{c|} 
Capacidade de \\
Alojamento - Própria \\
\end{tabular}} & \multicolumn{2}{|c|}{$\begin{array}{c}\text { Capacidade de Alojamento } \\
\text { Produtores Integrados }\end{array}$} & \multirow{2}{*}{$\begin{array}{l}\text { Número de } \\
\text { Produtores } \\
\text { Integrados }\end{array}$} & \multirow{2}{*}{$\begin{array}{c}\begin{array}{c}\text { Capacidade Média de } \\
\text { Alojamento dos }\end{array} \\
\text { Integrados }\end{array}$} \\
\hline & N. ${ }^{\circ}$ Cabeças & $\% *$ & N. ${ }^{\circ}$ Cabeças & $\% *$ & & \\
\hline Empresa 1 & $\overrightarrow{-}$ & - & 5.530 .000 & 100,00 & 390 & 14.000 \\
\hline Empresa 2 & 102.000 & 42,00 & 139.000 & 58,00 & 13 & 10.600 \\
\hline Empresa 3 & 900.000 & 58,44 & 640.000 & 41.56 & 17 & 37.647 \\
\hline Empresa 4 & 300.000 & 24,00 & 950.000 & 76,00 & 35 & 27.143 \\
\hline Empresa 5 & 470.000 & 38,52 & 750.000 & 61,48 & 25 & 30.000 \\
\hline Empresa 6 & - & - & 200.000 & 100,00 & 13 & 15.380 \\
\hline Empresa 7 & 1.114 .000 & 19.54 & 4.588 .000 & 80.46 & 432 & 10.620 \\
\hline TOTAL & 2.886 .000 & 18,40 & 12.797 .000 & 81.60 & 925 & - \\
\hline
\end{tabular}

* Percentual em relação à produção total de cada empresa.

Fonte: Dados da Pesquisa

Ao analisar a tabela 5, alguns pontos importantes merecem ser destacados. Em primeiro lugar, chama a atenção o significativo número de produtores submetidos ao 
processo produtivo em um número relativamente pequeno de empresas. Como foi visto anteriormente, o número de produtores integrados contratualmente representa em torno de $67 \%$ do total de produtores de frango de corte do Estado. A concentração torna-se ainda maior, quando se observa que apenas duas empresas agregam $88,87 \%$ do total dos produtores integrados.

Outro fator a ser destacado é que estas empresas dependem fundamentalmente da produção integrada, uma vez que $81,6 \%$ da capacidade de alojamento pertencem aos produtores.

Quanto às exigências que são feitas aos produtores quando desejam integrar-se, é importante inicialmente ressaltar dois pontos: das empresas pesquisadas, uma já atua neste sistema produtivo há mais de 15 anos. Desta forma, à medida que a empresa foi crescendo as exigências também foram modificando-se. Inicialmente aceitava-se o produtor com o galpão que ele já possuía, hoje procura-se padronizá-los. $\mathrm{O}$ outro ponto diz respeito às empresas que estão iniciando-se neste sistema mais recentemente. Elas são mais exigentes, mas podem relaxar um pouco nas exigências caso necessitem de mais produtores com certa urgência. A tabela 6 traz as principais exigências que estão sendo feitas pelas integradoras atualmente.

Pode-se observar, com exceção da empresa 6, que exige um galpão de $1500 \mathrm{~m}^{2}$ e propriedade com área superior a 25 ha, que a capacidade de alojamento exigida pelas demais empresas é relativamente baixa, até menor do que o mínimo economicamente recomendável, possibilitando desta forma a entrada de pequenos produtores na atividade. Isto revela que o problema de escala produtiva deixa de existir para a empresa integradora, uma vez que ela pode agregar um número relativamente grande de integrados, tendo talvez como limitante a capacidade de abate. Do lado do produtor resolve-se também um grande problema; ao eliminar a questão da comercialização, na qual o tamanho da capacidade produtiva é relevante, o produtor pode-se preocupar apenas com o tamanho que para ele é possível adotar. 
Tabela 6 - Exigências feitas aos produtores atualmente para integrarem-se contratualmente - Minas Gerais/1995

\begin{tabular}{|c|c|}
\hline EMPRESA & EXIGÊNCIAS \\
\hline Empresa 1 & $\begin{array}{l}\text { - distância máxima do abatedouro em torno de } 70 \mathrm{Km} \text {; } \\
\text { - galpão devidamente equipado para no mínimo } 6.000 \text { aves. }\end{array}$ \\
\hline Empresa 2 & $\begin{array}{l}\text { - distância máxima do abatedouro em torno de } 50 \mathrm{Km} \text {; } \\
\text { - galpão equipado com ventiladores e nebulizadores para no mínimo } 6.000 \text { aves. }\end{array}$ \\
\hline Empresa 3 & $\begin{array}{l}\text { - distância máxima da fábrica de ração em torno de } 50 \mathrm{Km} \text {; } \\
\text { - no caso desta empresa, como todos os integrados eram produtores independentes } \\
\text { anteriormente, a empresa aceita independente do tamanho da capacidade de alojamento. }\end{array}$ \\
\hline
\end{tabular}

Empresa 4 - distância máxima da fábrica de ração em torno de $80 \mathrm{Km}$;

- capacidade de alojamento entre 5.000 e 50.000 aves, desde que tenha disponibilidade de equipamentos.

Empresa 5 - distância máxima da fábrica de ração em torno de $80 \mathrm{Km}$;

- capacidade de alojamento entre 5.000 e 50.000 aves, desde que tenha disponibilidade de equipamentos.

Empresa 6 - distância máxima do abatedouro em tono de $80 \mathrm{Km}$;

- propriedade acima de 25 ha;

- galpão padrão com $1500 \mathrm{~m}^{2}$ e capacidade de alojamento de 18.000 aves, devidamente equipado;

- se o proprietário mora na propriedade ele tem preferência na seleção.

Empresa 7 - distância máxima do abatedouro em torno de $40 \mathrm{Km}$ :

- galpão padrão devidamente equipado para no mínimo 10.000 aves.

Fonte: Dados da Pesquisa

Em entrevista pessoal com o responsável pelo setor de integração da empresa 6, a justificativa para a exigência daquele tamanho de galpão ${ }^{13}$ é a facilidade de mecanização do mesmo, ou seja, caso a empresa futuramente passe a exigir comedouros automáticos, este tamanho de galpão comportaria um sem problemas. Quanto ao tamanho da propriedade, a empresa está visando o consorciamento da atividade avicola com outras atividades afins. A intenção da empresa é que a cama de frango seja preparada com capim, e que o mesmo seja plantado na propriedade, além do reaproveitamento da mesma como esterco e/ou ração animal.

${ }^{13}$ De acordo com a própria empresa, em fevereiro de 1996 um galpão de $1500 \mathrm{~m}^{2}$ estava orçado em RS $60.000,00$, incluindo comedouro automático e piso rico, ou piso de cimento. Cabe salientar que o comedouro automático ainda não é uma exigência da empresa, diminuindo o orçamento em torno de $R \$ 12.000,00$. 
Esta preocupação é pertinente e será discutida com mais detalhes na segunda parte da análise dos resultados, quando será analisada a viabilidade econômica dos contratos de integração.

Dado o grande número de produtores submetidos a este sistema de produção congregados a um número tão pequeno de empresas, torna-se relevante salientar o grau de organização destes produtores em relação às empresas. Apenas os produtores integrados às empresas 1 e 7 estão organizados em associações, e mesmo assim, o grau de organização dos produtores não é grande, pelo menos na empresa 1.

Dos 390 produtores integrados à empresa 1 , em torno de $50 \%$ estão vinculados a uma associação. A entidade tem como principal objetivo representar os integrados junto à empresa no que diz respeito a problemas relacionados a remuneração, além de negociar a comercialização do esterco de frango para aqueles que não o utilizam na propriedade. Para a manutenção da associação, os produtores contribuem com $1 \%$ do valor recebido pelo lote produzido.

A organização dos produtores da empresa 7 pode ser considerada satisfatória. Todos os avicultores ao entrarem no sistema de integração desta empresa, filiam-se automaticamente à associação e a contribuição é de $2 \%$ do valor do lote produzido. $\mathrm{O}$ que mais chamou a atenção na condução desta associação é que muito mais do que servir de intermediária entre os produtores e a empresa para resolver problemas relacionados a remuneração, a associação é a representante direta dos integrados junto às prefeituras. Neste caso, a grande contribuição da associação é conseguir junto às prefeituras o melhoramento das estradas que dão acesso às granjas. A empresa, de um modo geral, recusa-se a entregar os pintinhos caso o acesso a propriedade esteja ruim.

Outro trabalho interessante feito pela associação foi a implantação de um secador de capim comunitário. A cama de frango preparada com este material é uma das mais valorizadas da região e sua secagem tem um custo elevado caso seja feita por cada produtor em sua propriedade. A associação também tem uma publicação bimestral, na qual mostra a atualidade avícola e a cotação do preço da cama de frango da região, além de listar os melhores produtores do bimestre com os respectivos índices alcançados. 
Nas demais empresas não existe nenhum tipo de organização por parte dos produtores. Acredita-se que isto acontece devido ao pequeno número de integrados de cada uma delas. $\mathrm{O}$ depoimento dos representantes destas empresas foi de que, caso exista algum problema, o mesmo é resolvido diretamente com o produtor.

\section{3 - Características dos contratos de integração vertical na produção de frango de corte no Estado de Minas Gerais}

Apesar dos contratos de integração para a produção de frango de corte serem usados em diferentes regiões do Estado de Minas Gerais, eles apresentam cláusulas bem semelhantes, podendo ser classificados como contratos integrais definidos pelo BADESP (1978).

De maneira geral, o contratante ou integrador é representado por uma indústria, que tem como principal obrigação fornecer ao contratado ou integrado, em sua propriedade, os insumos necessários à produção de frango de corte. Nos contratos é deixado claro que os insumos pertencem à indústria, sendo o integrado apenas um fiel depositário dos mesmos.

Os insumos referem-se a pintos de um dia de boa qualidade, ração, medicamentos e assistência técnica necessária durante a engorda das aves. Em dois contratos ( $\mathrm{B} \mathrm{e} \mathrm{C}$ ) as empresas comprometem-se a fornecer também o gás necessário ao aquecimento das aves, bem como a suprir despesas com a apanha dos frangos. Cabe salientar, que estes dois insumos juntos têm um peso significativo na planilha de custo dos produtores, girando em torno de $27 \%$. Ao avicultor integrado cabe fornecer além de instalações devidamente equipadas para a engorda das aves, energia elétrica, material para a cama, mão-de-obra necessária ao manejo e limpeza, como também mão-de-obra para o dia da apanha dos frangos, incluídos todos os encargos sociais.

Em todos os contratos percebe-se claramente que cabe ao integrador toda a parte de tomada de decisão. Ele decide o quanto e quando entregar pintos de um dia, como também o tempo de alojamento das aves. Apesar da integradora comprometer-se a manter os galpões em plena utilização da capacidade instalada, o que se observa na 
prática, de acordo com o depoimento de alguns produtores, é a entrega de pintos de um dia inferior à capacidade de alojamento.

O que distingue bastante os contratos de integração analisados são as fórmulas de remuneração ou o método de cálculo para a determinação do preço do frango ao produtor integrado. Cabe salientar, no entanto, que neste sistema de produção, não se deve considerar que o preço recebido pelo produtor é o preço de venda do frango, isto porque, o frango não lhe pertence. Este preço reflete unicamente a compensação pela engorda dos mesmos.

Em todos os contratos os produtores integrados são remunerados dependendo dos resultados alcançados medidos por variáveis técnicas. $\mathrm{O}$ número de variáveis e o peso que cada uma recebe nas fórmulas é que difere de um contrato para outro. Não se observou em nenhum dos contratos a apuração explícita do custo total de produção, ou seja, o valor líquido a ser recebido pelo produtor é apurado diretamente das fórmulas de remuneração, que resultam nos casos dos contratos A e B em peso de frango vivo e, nos casos dos contratos $\mathrm{C}$ e $\mathrm{D}$ em valor monetário direto. Isto, implica dizer que independente do custo da ração ou do pinto de um dia para a empresa, elas já os incluem nas fórmulas. $\mathrm{O}$ que fica claro no caso dos contratos $\mathrm{A}$ e $\mathrm{B}$, os quais possuem uma tabela de índices de coeficientes técnicos, é que, para o primeiro caso, o produtor terá como remuneração pela engorda dos frangos, no máximo $12 \%$ do total de quilos de frango produzidos. Para o contrato B, este limite chega a $21,3 \%$ do total produzido, cabendo salientar, que a média alcançada pelos produtores no ano de 1995 , foi de apenas $8,9 \%$.

De acordo com os representantes das empresas, as fórmulas de remuneração são as mesmas desde o início do sistema de integração, somente no caso do contrato A, em que a apuração baseia-se na tabela apresentada na página 97, a empresa declarou que pode haver mudanças na mesma, não ocorrendo no entanto com freqüência.

No contrato $\mathrm{B}$, a parcela pertencente ao integrado é expressa em quilos de aves vivas calculado de acordo com desempenho, que o produtor poderá ou não vender à integradora. Na prática o integrado nunca fica com os frangos uma vez que a integradora tem sempre preferência pela aquisição. Neste caso, feita a partilha, o preço 
que o integrado receberá pelo quilo de ave viva é o cotado pela Associação Paulista de Avicultura (APA) na data do abate. No contrato A, apesar do cálculo ser feito também em quilos de aves vivas, não existe nenhuma cláusula neste sentido. Nos outros dois contratos o valor a ser calculado já é expresso em unidade monetária.

A utilização do preço cotado pela APA como indexador do valor a ser pago aos produtores mineiros em alguns contratos, é questionável, uma vez que também existe uma cotação de preço em Minas Gerais, feita pela Bolsa de Frango, como descrita anteriormente. Apesar desta cotação também ser questionável, isto porque é feita com pequena participação dos representantes do setor, a utilização do preço APA, deve estar refletindo de alguma forma, a importância do mercado avicola paulista não só como produtor, mas como um grande consumidor.

Mesmo de posse das fórmulas de remuneração não é fácil determinar de fato o que representa o preço para o integrado. Em apenas dois contratos (A e B), percebe-se claramente a influência de um preço de mercado (preço do frango vivo cotado pela APA) afetando diretamente o valor recebido pelo produtor. Nos outros dois contratos (C e D) isto não ocorre, deixando transparecer que o preço não deverá oscilar muito ao longo do tempo. $O$ que se pode afirmar das fórmulas e tabelas de remuneração, é que elas são construídas a partir da curva de custo de produção das empresas, que é afetada diretamente pela conversão alimentar. $O$ que as empresas desejam é o óbvio; menor quantidade de ração consumida para maior quantidade de carne produzida. Quanto mais eficiente for um produtor em fazer com que as aves transformem ração em carne, maior deverá ser sua participação no produto final.

Em apenas um dos contratos (contrato D), a remuneração ao integrado leva em consideração o custo em que ele incorre na engorda dos frangos. $O$ valor do ponto a que o contrato refere-se é calculado levando-se em consideração a planilha de custo com os fatores de produção para um galpão de $1200 \mathrm{~m}^{2}$. Esta planilha é elaborada pela empresa integradora juntamente com a associação de produtores.

Um outro ponto interessante nos contratos diz respeito à cama ou esterco. Apesar de ser um subproduto da atividade e o custo de sua preparação correr por conta 
do integrado, em dois contratos é explicitado que o esterco será revertido ao produtor como valor fixo devido pela integradora.

Para deixar um pouco mais clara a questão da remuneração, ou de como o preço é estabelecido ao produtor, suponha o seguinte resultado: Um integrado alojou em outubro de 1995, 21.800 pintos de um dia, entregando ao final de 45 dias 20.867 frangos com um peso total de $46.000 \mathrm{~kg}$. $O$ desempenho do produtor neste lote foi: mortalidade $4,28 \%$, peso médio $2,204 \mathrm{~kg}$, conversão alimentar de 2,17 , ganho de peso diário de 48,14 $\mathrm{g}$ e idade de 45 dias. O preço do quilo de frango vivo cotado pela APA em dezembro de 1995, época de retirada do frango foi de $R \$ 0,6488$.

Pelo contrato A, observando a tabela da página 97 , o referido produtor teria direito a $8,0 \%$ do total de frango entregue, que transformado em valor monetário seria $\mathrm{R} \$ 2.387,58$. Pelo contrato B, o integrado teria um IEP de 216, que pela tabela da página 102 , alcançaria um percentual de $7 \%$, que colocado na fórmula o renderia $R \$$ $2.089,13$. Pelo contrato $\mathrm{C}$, com a mesma performance o produtor teria um fator de produtividade (FP) de 212. Colocado na fórmula da página 104, e utilizando-se de um fator de produtividade médio de 218 , resultaria em uma remuneração de $R \$ 2511,60$, e finalmente pelo contrato $\mathrm{D}$ o integrado receberia $\mathrm{R} \$ 2.714,00$. À primeira análise afirmarse-ia sem dúvida, que a fórmula do contrato $\mathrm{D}$ é a que melhor remunera e a do contrato $\mathrm{B}$ a pior. Uma análise mais aprofundada diria que isto pode não ser verdadeiro. O que é custo para o produtor em um contrato pode não ser em outro. A pura análise do preço recebido pelo produtor pode não explicar de forma clara o que de fato ele representa, isto porque algumas empresas fornecem o gás e a mão-de-obra para apanha dos frangos. Com os resultados da análise da viabilidade econômica do investimento a partir de cada contrato, que serão apresentados no próximo item, espera-se um melhor esclarecimento destas relações neste sistema de produção.

Para ilustrar a representatividade do valor da cama de frango na receita do produtor integrado, tem-se que para o produtor utilizado no exemplo anterior, o seu galpão tem uma área de $1816 \mathrm{~m}^{2}$. Com esta área, retira-se em média $32,7 \mathrm{t}$ de esterco, que sendo vendido pelo valor médio praticado no periodo em análise, que foi de $\mathrm{R} \$ 56,6$ 
obter-se-ia pela venda o total de $\mathrm{R} \$ 1.850,52$. Comparando este valor com o recebido pela engorda dos frangos sob quaisquer dos contratos, percebe-se a grande participação do valor da cama na receita total.

Quanto ao prazo de pagamento pela engorda dos frangos, em todos os contratos gira em torno de 10 a 15 dias da data de abate.

Quanto ao tempo de duração, os contratos variam de seis (6) meses a prazo indeterminado. $O$ tempo de vigência do contrato parece não ser uma cláusula muito importante. A renovação é sempre automática e a rescisão pode acontecer quando qualquer uma das partes sentir-se lesada ou simplesmente quiser sair do processo de produção, desde que seja anunciado com certa antecedência.

Em todos os contratos existem uma ou mais cláusulas que ditam as penalizações a que estão sujeitos os integrados caso não cumpram as normas estabelecidas nos mesmos. De maneira geral estas cláusulas são estabelecidas dado o risco que a empresa corre com os insumos fornecidos aos produtores. No contrato $\mathrm{A}, \mathrm{o}$ não cumprimento de quaisquer das disposições sujeitará $\mathrm{o}$ faltoso a uma multa. $\mathrm{O}$ contrato $\mathrm{D}$ também estabelece uma multa, mas além disso é estabelecido um minimo de eficiência que o produtor deverá atingir, caso não a alcance a empresa poderá ficar com a cama de frango. De acordo com depoimento de representante desta integradora, o integrado está sujeito a uma avaliação constante, ou seja, ele não poderá persistir em um índice técnico muito abaixo da média esperada pela empresa. A má condução do plantel que resulte em um constante resultado ruim, fatalmente eliminará o produtor deste sistema de produção. Esta mesma posição é tomada também no contrato B, no qual o produtor terá direito a três advertências, caso não sejam atendidas resultará em cancelamento do contrato.

\section{4 - Análise da rentabilidade do investimento}

Utilizando-se do método de simulação definido no item 2.2.1, que compreende a geração de valores ao acaso para as variáveis selecionadas, obteve-se as distribuições de freqüência da taxa interna de retorno (TIR), que são apresentadas nas tabelas $7,8,9$ e 10. A frequêencia relativa da TIRs foi tomada como medida de 
probabilidade de que as TIRs indicadas nos intervalos de cada tabela venham ocorrer, sob as condições de risco consideradas.

Dada a importância da cama de frango nesta atividade, procedeu-se a simulação considerando diferentes valores para a mesma. Para se fazer comparações entre os contratos e dentro do mesmo contrato com diferentes valores para a cama de frango, o programa foi feito para gerar sempre o mesmo valor da função de distribuição de probabilidade de cada variável. Desta forma, é possível captar o quanto o valor da cama de frango altera a rentabilidade do investimento mantendo-se constante o mesmo nível de eficiência técnica.

Inicialmente a simulação foi feita com o valor médio da tonelada da cama de frango verificado no período de fevereiro de 1995 a fevereiro de 1996, que foi de R\$ 56,60. Posteriormente, procedeu-se a simulação com um e dois desvios padrões à direita e esquerda. $O$ valor de um desvio padrão foi de $\mathrm{R} \$ 11,67$. Como para todos os contratos o investimento mostrou-se viável quando comparado à maior taxa do custo médio ponderado do capital (CMPC) que foi de 13,7\% ao ano, optou-se por fazer a análise apenas com resultados encontrados quando utilizados os valores $R \$ 44,93$ e $R \$ 33,26$, que representam respectivamente um e dois desvios padrões à esquerda do valor médio.

As freqüências relativas das taxas internas de retorno contidas nas tabelas 07, 08, 09 e 10, serão tomadas como medida de probabilidade, e a partir da comparação com o custo médio ponderado do capital, será possivel tirar conclusões do grau de risco do investimento, de acordo com cada contrato analisado.

Tem-se a seguir os três diferentes valores para o custo médio ponderado do capital (CMPC), que foram calculados no item 2.4.

$\Rightarrow 13,7 \%$ ao ano, para avicultores que financiam $70 \%$ do investimento com recursos de terceiros;

$\Rightarrow 11,50 \%$ ao ano, para avicultores que investem com $50 \%$ de capital próprio e $50 \%$ com capital de terceiros e;

$\Rightarrow 6 \%$ ao ano, para avicultores que investem $100 \%$ de recursos próprios, considerando o rendimento da caderneta de poupança como custo do capital. 
A tabela 7 traz os resultados para o caso do contrato A . Considerando o resultado da taxa interna de retorno utilizando-se o valor médio para a cama de frango, observa-se que para o CMPC de $13,7 \%$ ao ano, o investimento tem um risco elevado uma vez que, $93 \%$ das situações geradas pela simulação apresentam uma TIR menor que $13,5 \%$ ao ano. Prevalecendo este custo do capital, qualquer desvio à esquerda do valor médio praticado para a cama de frango inviabiliza totalmente o investimento.

Se o CMPC for de $11,50 \%$ ao ano, verifica-se que este valor encontra-se no intervalo de taxa interna de retorno de $11,50 \%$ a $12 \%$ ao ano, com uma probabilidade de ocorrência de $4,9 \%$. Tomando a freqüência relativa acumulada, a probabilidade de ocorrer um valor maior que $11,50 \%$ é de $99,8 \%$, mostrando que neste caso a situação de rentabilidade do projeto é confortável, caso o produtor consiga pela comercialização da cama, o valor médio. Com o mesmo CMPC, um desvio à esquerda do valor da cama torna o investimento totalmente inviável.

Com o CMPC de $6 \%$ ao ano, a viabilidade do investimento aumenta de maneira considerável. Mesmo com um desvio à esquerda para o valor da cama, a probabilidade de ocorrer uma taxa interna de retorno maior que $6 \%$ ao ano é de $99,8 \%$. No entanto, com dois desvios à esquerda o investimento revela-se inviável.

Foi feita a simulação para todos os contratos com o valor nulo para a cama de frango, sendo gerada para todos os contratos taxas internas de retorno negativas. Os valores médios foram $-15,89,-8,53,-9,37$ e $-11,10 \%$ ao ano, respectivamente para os contratos $\mathrm{A}, \mathrm{B}, \mathrm{C}$ e $\mathrm{D}$. Revela-se neste caso, que não sendo considerado o valor da cama como fonte de receita, o projeto torna-se totalmente inviável independente do contrato e fórmula de remuneração a que está submetido o produtor integrado. 


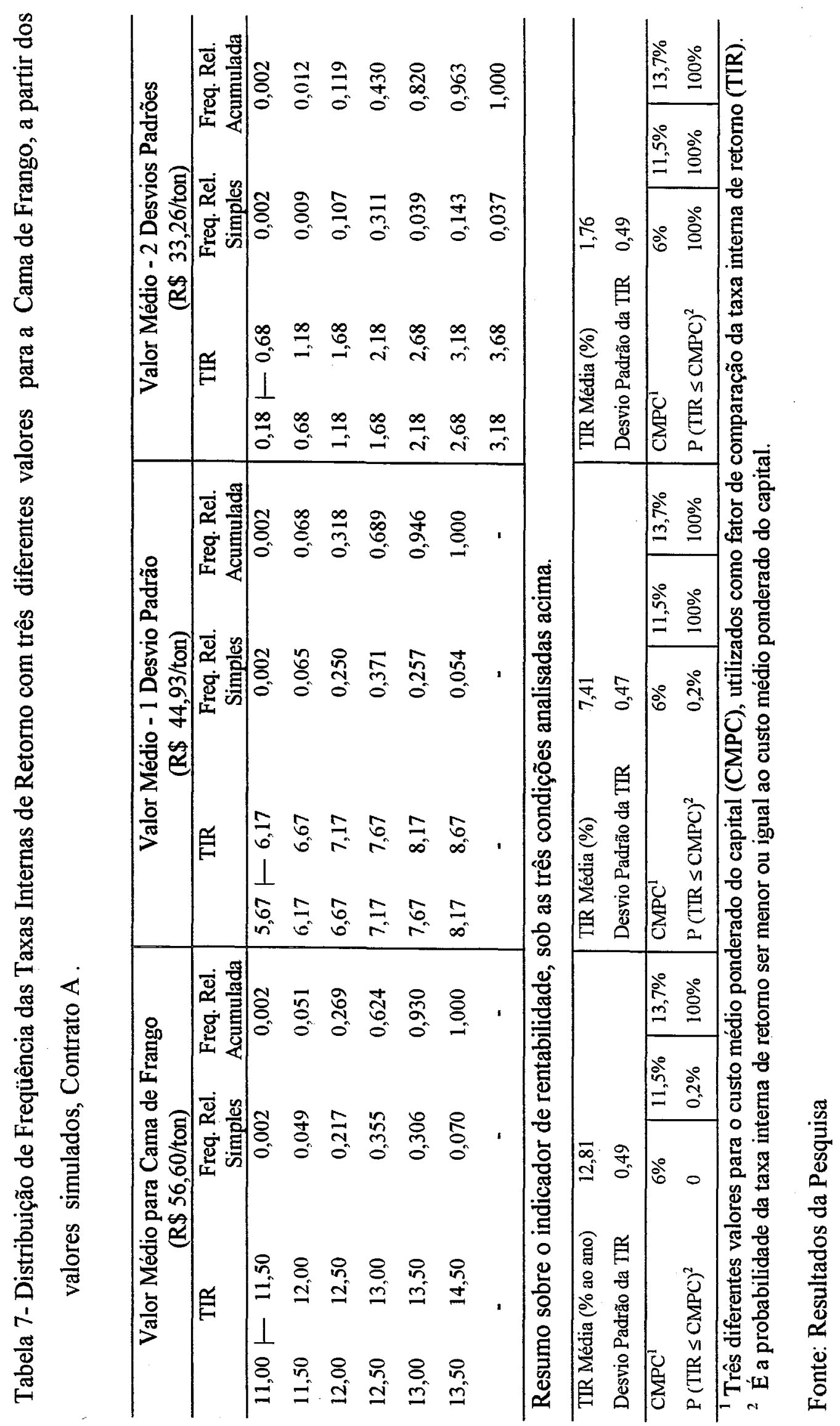


A tabela 8 traz os resultados para o contrato $\mathrm{B}$. Considerando o valor médio para a cama de frango, independente do CMPC ser qualquer um dos três valores, mesmo sob condições de risco, o investimento é viável economicamente. Entre taxas internas de retorno de 16,89 a $19,89 \%$ ao ano, pode ocorrer qualquer valor com uma freqüência acumulada relativamente alta, em torno de 79,5\%. Apesar de terem sido geradas taxas internas de retorno no intervalo de 19,89 a $22,89 \%$ ao ano, as probabilidades são pequenas, acumulando-se em torno de $15,6 \%$.

Quando considerado um desvio padrão à esquerda para o valor da cama de frango e tendo inicialmente um CMPC de 6\% ao ano, o investimento não encontra problemas de viabilidade. A menor TIR encontrada foi de 10,34\% ao ano. No entanto, se os avicultores tiverem o CMPC de 11,50 ou 13,7\% ao ano, existem possibilidades de inviabilidade do investimento. Para o primeiro caso a probabilidade é pequena, uma vez que $11,5 \%$ encontra-se no intervalo de 11,34 a $11,84 \%$ ao ano, com uma pequena probabilidade de ocorrência, $2,34 \%$ com uma freqüência acumulada de apenas $2,5 \%$. Isto implica dizer que a probabilidade de ocorrer uma TIR maior que $11,5 \%$ ao ano é de $97,5 \%$.

Para o CMPC de $13,7 \%$ ao ano, a situação torna-se um pouco desconfortável, mas ainda existindo possibilidades de se encontrar uma taxa interna de retorno maior que $13,7 \%$ ao ano. Esta taxa encontra-se no intervalo de 13,34 a $13,84 \%$ com uma probabilidade de $21 \%$. A freqüência acumulada é de $56,3 \%$, revelando que neste caso, a probabilidade de encontrar uma TIR igual ou menor que o CMPC é de $56,3 \%$.

Caso o valor da cama sofra dois desvios padrões à esquerda, o investimento submetido a este contrato teria sérios problemas para tornar-se viável. Caso o CMPC seja de 6\% ao ano existe a probabilidade de ocorrência de TIRs superiores ao custo do capital em torno de 99\%. Mas, considerando-se um CMPC de 11,5 ou 13,7\% ao ano, o investimento com quase $100 \%$ de probabilidade não se torna viável. Foi gerado apenas um intervalo que inclui a taxa de $11,5 \%$, com uma probabilidade muito pequena 


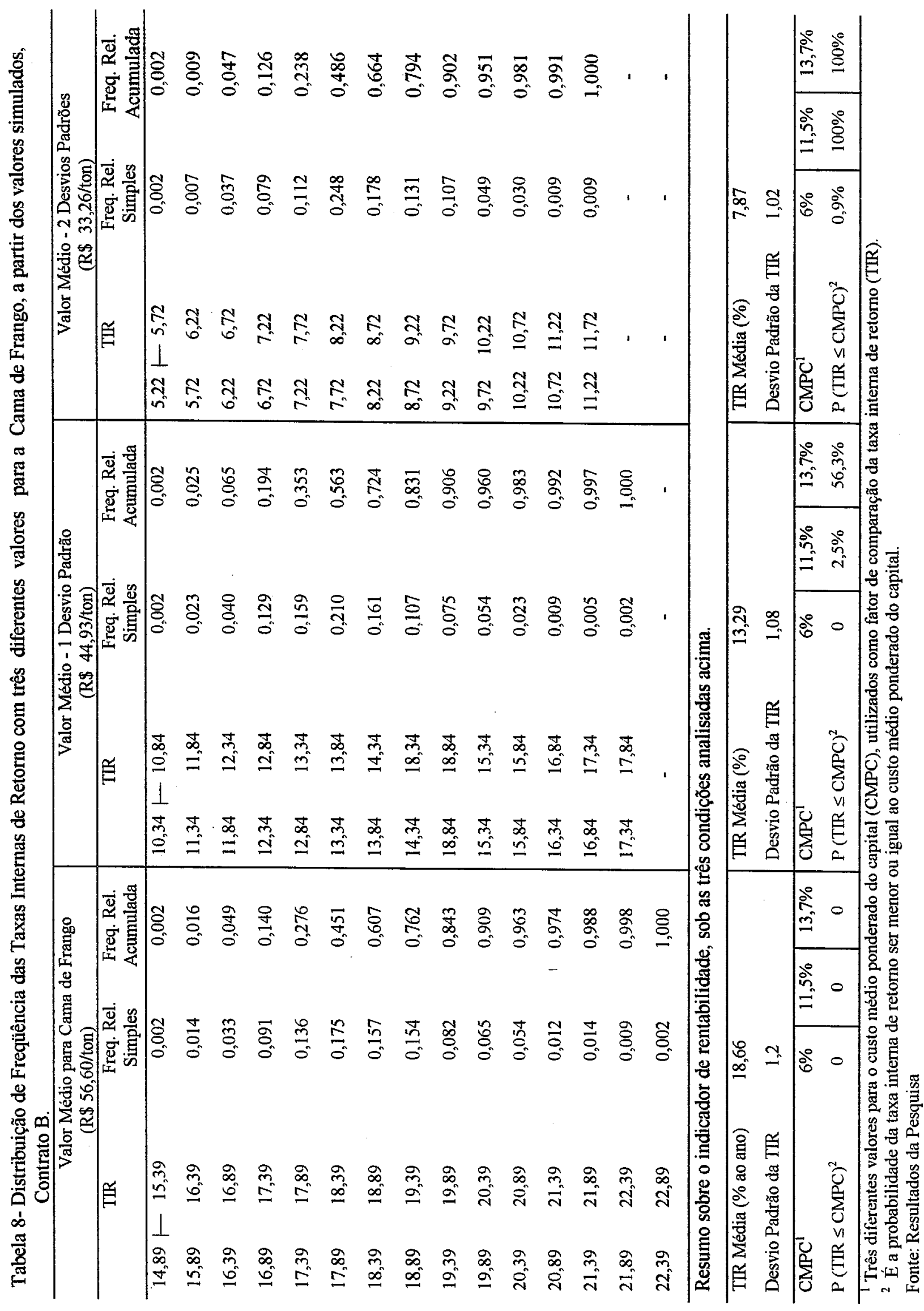


de ocorrência, apenas $0,9 \%$. Os demais valores gerados são todos inferiores aos custos em questão.

Neste ponto é interessante fazer um paralelo entre os contratos $\mathrm{A}$ e $\mathrm{B}$, cuja rentabilidade foi analisada anteriormente. Dos contratos analisados nesta dissertação, apenas estes dois têm um preço de mercado servindo de referência para o valor que o produtor receberá. Cabe, no entanto, salientar que o preço do quilo de frango cotado pela APA faz simplesmente o total em peso vivo a que o produtor tem direito transformar-se em valor monetário. Neste caso, os valores simulados para o preço APA foi sempre o mesmo para os dois contratos. Isto revela que a diferenciação ocorre devido à fórmula de remuneração, ou seja, no cálculo do peso de frango a que o produtor terá direito.

No caso do contrato $A$, apenas leva-se em consideração o peso médio e a conversão alimentar e para o contrato $B$, existe a combinação de quatro variáveis, quais sejam; peso médio, conversão alimentar, mortalidade e idade de alojamento. Isto pode estar contribuindo para uma melhor distribuição do peso das variáveis. Mas, um fator que muito provavelmente deve estar colaborando para o melhor resultado do contrato $\mathrm{B}$ em relação ao contrato $\mathrm{A}$ é que, no primeiro, a empresa compromete-se a pagar despesas relacionadas à apanha do frango e gás. Como foi dito anteriormente, estas duas despesas respondem por aproximadamente $27 \%$ do total de custo que o produtor tem com a engorda dos frangos. Cabe, no entanto, ressaltar que, segundo depoimento do representante da própria associação de produtores, esta não é uma prática que sempre prevaleceu nesta empresa. Como a fórmula de remuneração dificilmente é alterada, quando o valor pago ao produtor em média tem uma queda muito acentuada, a empresa utiliza-se de algum artificio para reverter a situação. Segundo representante da associação, o preço médio ao produtor deve sempre ficar em torno de 60 dólares a tonelada de peso vivo.

Outro fator que pode estar contribuindo para esta diferenciação diz respeito à representatividade da produção integrada em cada uma das empresas. No primeiro caso, existem apenas 17 avicultores integrados produzindo $41,56 \%$ do total da produção da empresa, enquanto que no segundo caso, existem 390 integrados 
produzindo $100 \%$ da produção da empresa. Neste caso, deve existir uma pressão destes produtores por uma remuneração melhor em comparação aos primeiros.

Como foi dito anteriormente, dos quatro contratos analisados, os contratos $\mathrm{C}$ e $\mathrm{D}$ não se utilizam explicitamente de nenhum preço de mercado como balizador ou referencial para o preço a ser pago ao produtor. Nos dois contratos as fórmulas de remuneração foram construídas de tal forma que fosse obtido o resultado final em valor monetário.

A tabela 9 mostra os resultados encontrados para as taxas internas de retorno do contrato C. Em relação a todos os outros contratos, este foi o que apresentou maior amplitude entre o menor e maior valor da taxa interna de retorno gerada.

Utilizando-se do valor médio para a cama de frango, o investimento submetido a este contrato não tem problemas para tornar-se viável independente de qualquer um dos três custos médios ponderados do capital. No entanto, a probabilidade de ocorrer um ou outro intervalo de taxa interna de retorno não é bem definida, concentrando-se no intervalo entre 15,09 a $19,59 \%$ ao ano com uma frequiência acumulada neste intervalo de $73,5 \%$. Mesmo tendo sido gerados valores relativamente altos de até $25,59 \%$ ao ano, a probabilidade individual de cada intervalo é relativamente baixa, acumulando-se de 19,59 a $25,59 \%$ ao ano em torno de $14,5 \%$. Para o CMPC de $13,7 \%$ ao ano, apesar da probabilidade de ser gerada uma taxa interna de retorno menor que esta ser muito pequena, ela existe e é em torno de $3 \%$.

Caso o valor da cama de frango sofra uma queda de um desvio padrão do valor médio, a situação do investimento complica-se um pouco mas, ainda com possibilidades de tornar-se viável. Com o CMPC de $6 \%$ ao ano todos os valores gerados são superiores a este custo. A situação muda caso o avicultor tenha um custo de $11,5 \mathrm{ou}$ $13,7 \%$ ao ano. Com um custo médio ponderado do capital de $11,5 \%$ ao ano, existe uma probabilidade de $26,6 \%$ de ser gerado um valor inferior ao custo. Apesar de ter sido gerado taxa interna de retorno de até $19,33 \%$ ao ano, a probabilidade é pequena. Entre 15,33 a $19,33 \%$ ao ano a freqüência acumulada é de apenas $4,4 \%$. 


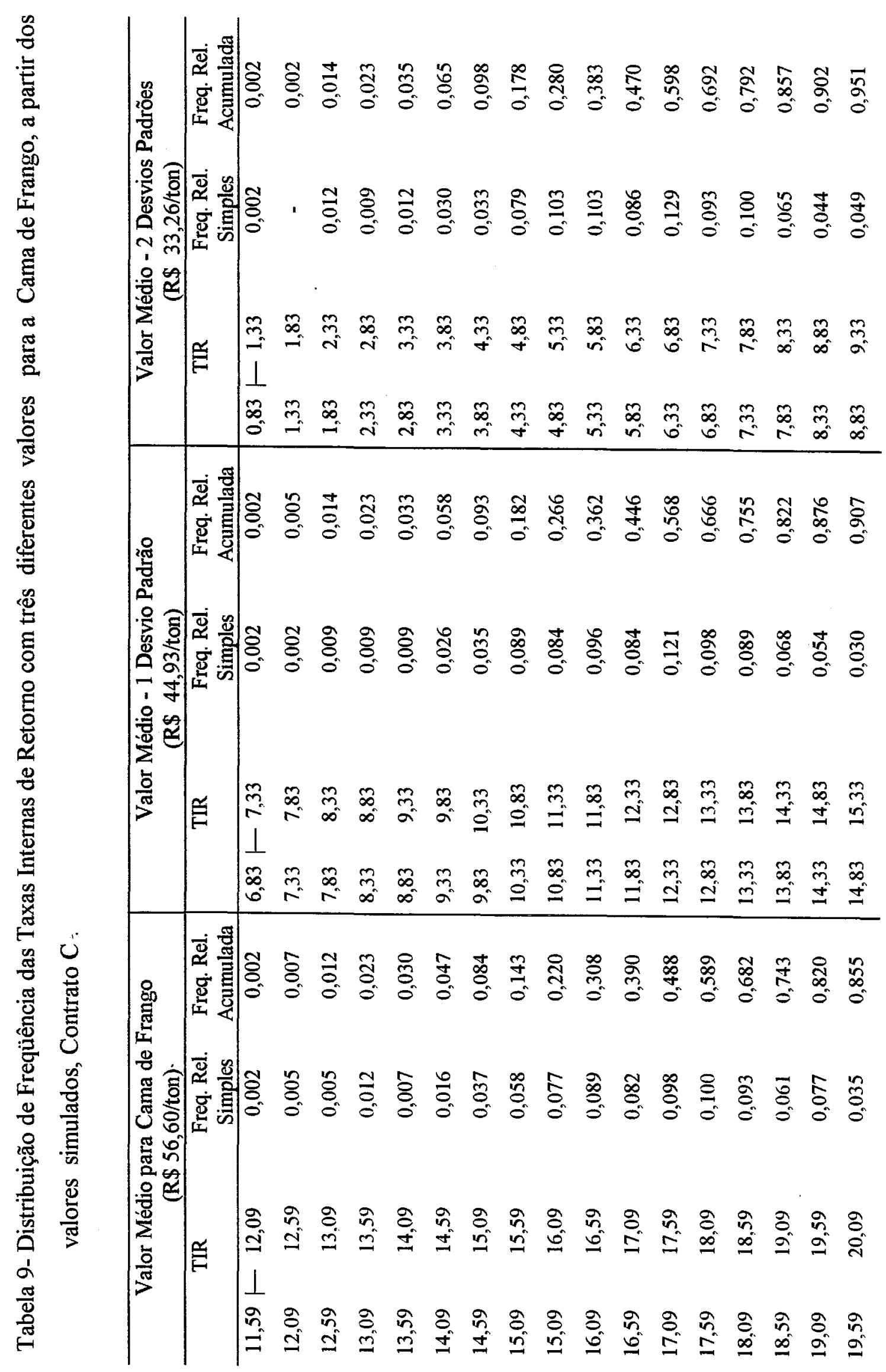




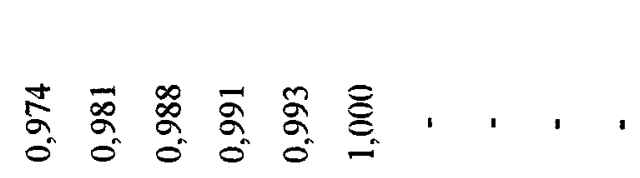

ڤิ

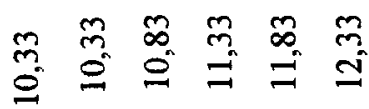

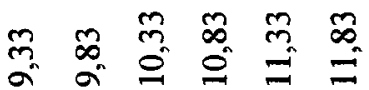

䒘

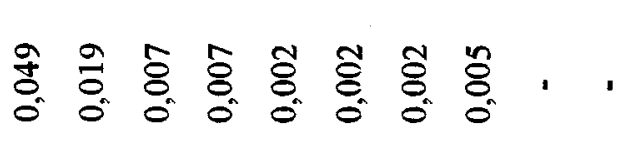

$\mid$

$\mid$\begin{tabular}{ll|}
$\stackrel{0}{*}$ & 8 \\
mे & 8
\end{tabular}

m

定

今े

递

$\mathscr{q}$

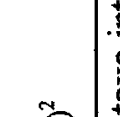

$\sum_{\mathrm{i}}^{0}$

导

舀

商

世

월

जू

옹 융

呇

空

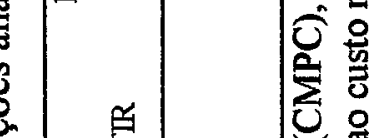

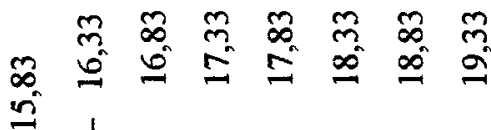

$\cong 1$

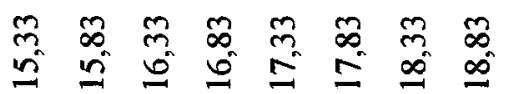

ڤ̆

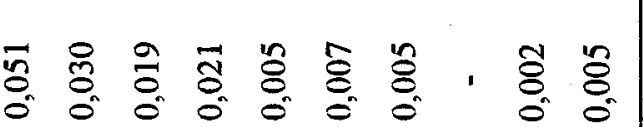

苍 要

过

흥

兒

î̀

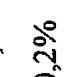

용

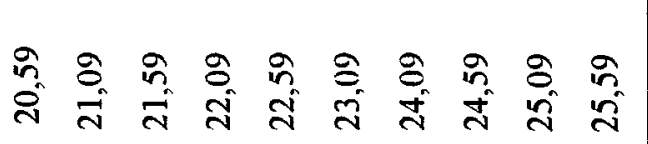

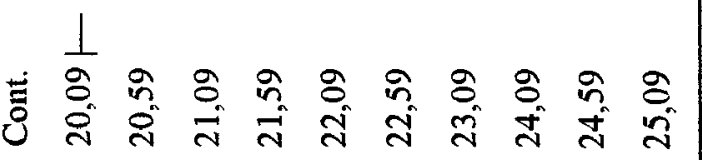


Para um CMPC de $13,7 \%$ ao ano, que se encontra no intervalo de taxa interna de retorno de 13,33 a $13,83 \%$ ao ano com uma probabilidade de ocorrência de $8,9 \%$, a situação torna-se muito delicada. Existe a probabilidade de $75,5 \%$ de ser gerada uma TIR menor que o custo do capital. Neste caso, o risco do investimento tornar-se relativamente acentuado. Com dois desvios padrões à esquerda do valor médio para a cama de frango, a situação torna-se extremamente complicada. Somente para um CMPC de $6 \%$ ao ano, existem possibilidades de serem geradas taxas superiores ao custo do capital. Entre 6,33 a 9,83\% ao ano, a probabilidade de ocorrência ficou em torno de $37,4 \%$, no entanto, com $47 \%$ de probabilidade poderão ser geradas taxas internas de retorno inferiores a $6 \%$ ao ano.

Para este contrato, é importante salientar que de acordo com o representante da empresa, os produtores têm feito financiamentos para construírem os galpões. Neste caso, o custo médio ponderado do capital não é apenas de $6 \%$ ao ano e, sim uma taxa superior, que no caso fica em torno de $13,7 \%$ ao ano. Desta forma, analisar os projetos com diferentes valores para a cama de frango, torna-se muito importante para avaliar-se de fato a viabilidade econômica do investimento.

Outro ponto que cabe ser destacado no caso deste contrato é que a empresa compromete-se a cobrir os gastos com o gás e a apanha do frango, que como foi dito anteriormente representa em torno de $27 \%$ do custo operacional do avicultor.

A tabela 10 traz os resultados para o caso do contrato $\mathrm{D}$, que da mesma forma que o contrato $\mathrm{C}$, não apresenta um preço de mercado servindo como balizador para o preço pago ao produtor.

Utilizando-se do valor médio para a cama de frango, a menor taxa interna de retorno gerada foi de $14,37 \%$ ao ano, superior ao maior valor do custo médio ponderado do capital utilizado neste trabalho. Entre 15,87 e 18,87\% ao ano, a probabilidade de ocorrência é relativamente alta, em torno de $92 \%$. Isto revela, que mesmo introduzindo fontes de risco ao investimento, com este valor da cama, existem boas possibilidades de retorno. 


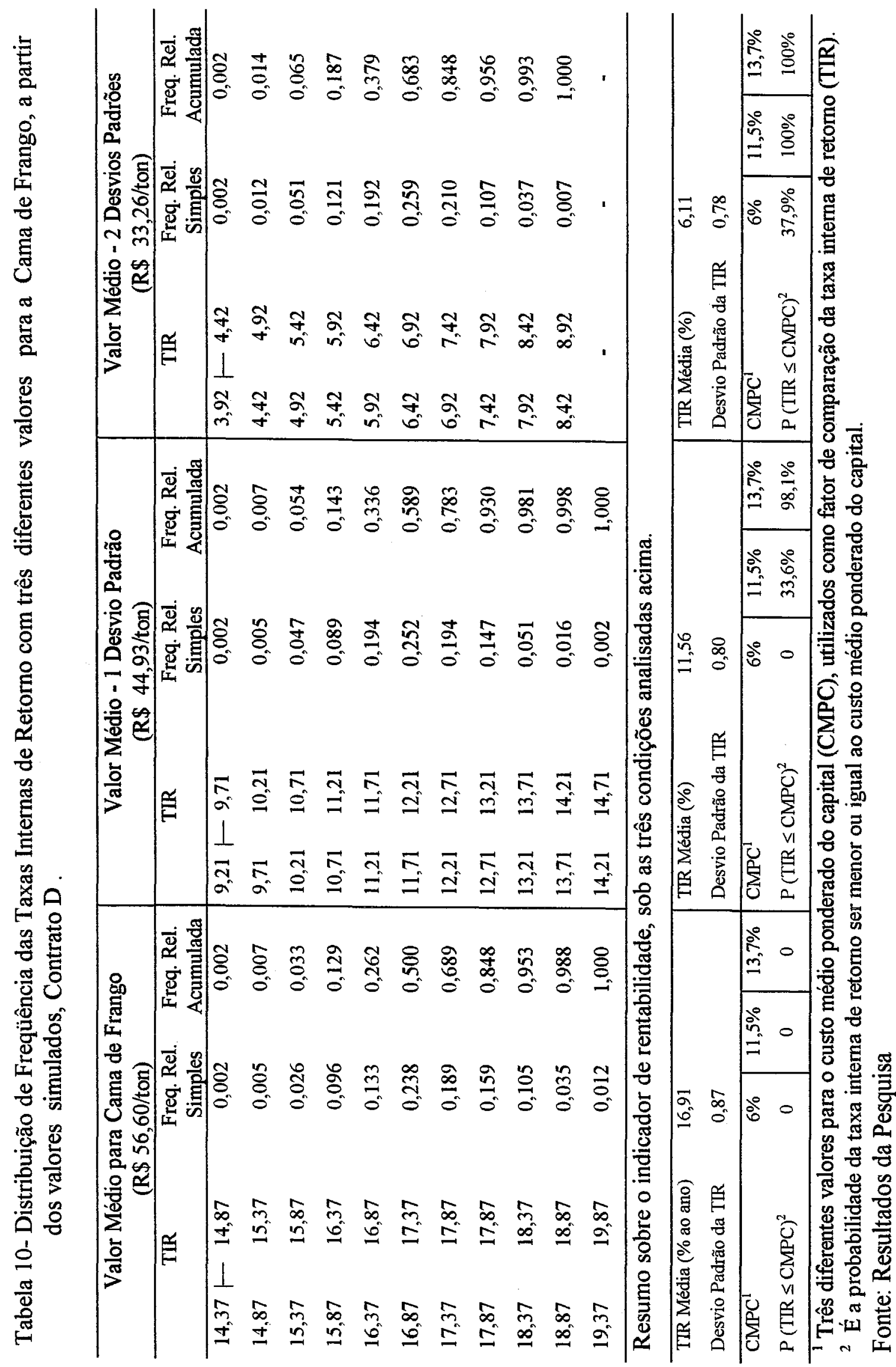


Caso ocorra um desvio padrão `a esquerda do valor médio para a cama, o investimento torna-se arriscado. Existem possibilidades de serem geradas taxas inferiores ao CMPC de $11,5 \%$ ao ano em torno de $33,6 \%$ e inferior a $13,7 \%$ de $98 \%$. Somente com um custo médio ponderado do capital de $6 \%$ ao ano, o investimento não encontra problemas para tornar-se viável.

Se ocorrerem dois desvios à esquerda para o valor da cama e mesmo com um CMPC de 6\% ao ano, o investimento tem sérias dificuldades para tornar-se viável, pois existem $37,9 \%$ de probabilidade de serem geradas taxas internas de retorno menores que o custo do capital.

No caso deste contrato, existe um acordo entre a empresa e os produtores no qual, a primeira ao final de cada lote de frango produzido deposita, em uma conta especial denominada conta galpão, a quantia de $\mathrm{R} \$ 0,2247$ (valor de fev. de 1996) por $\mathrm{m}^{2}$ de área construída. Este valor poderá ser canalizado somente para gastos com a granja, como reformas ou aumento da mesma.

Este procedimento torna-se interessante tanto para a empresa como para o integrado, uma vez que, como o dinheiro poderá ser utilizado somente na manutenção da granja, a empresa garante equipamentos e estruturas dos galpões sempre dentro de condições adequadas de utilização. Por parte do produtor, diminui a preocupação com a manutenção das granjas, uma vez que ele não precisará desembolsar dinheiro caso necessite de uma melhoria dos galpões.

Apesar das diferenças encontradas para os intervalos gerados de TIRs entre os contratos $\mathrm{C}$ e $\mathrm{D}$, cuja grande semelhança é a não utilização de um preço de mercado como balizador do preço pago ao produtor, as taxas concentram-se nos dois exemplos na casa dos 15 aos $20 \%$ ao ano.

Sob as mesmas condições de incertezas e nivel de eficiência técnica, os resultados encontrados para as TIRs a partir da simulação, revelam que as diferentes fórmulas de remuneração são capazes de gerar situações bem diferentes. A rentabilidade do investimento feito pelo produtor integrado pode variar de maneira notável. Considerando apenas o valor médio para a cama de frango e tomando em conjunto os 
resultados apresentados nas tabela 07,08, 09 e 10, verifica-se 11,00 e 25,59\% ao ano, como a menor e maior TIR gerada pela simulação. Se este resultado for comparado com outros trabalhos que utilizaram a mesma metodologia, como por exemplo Sá (1985), que analisou a rentabilidade econômica de engorda de bovinos em confinamento no Estado de Góias, cujas taxas variaram de -15 a $90 \%$ ao ano, a variabilidade da renda do produtor integrado é relativamente pequena.

Comparando agora os resultados encontrados com o trabalho de Lopes (1992), que também analisou contratos de integração avícola, a variabilidade foi praticamente a mesma. $\mathrm{O}$ autor analisou quatro contratos diferentes para o Brasil para 0 ano de 1991, encontrando 5 e $19 \%$ ao ano como a menor e maior taxa interna de retorno.

Um dos contratos analisados por Lopes também está sendo analisado nesta dissertação, que é o caso do contrato D. Apesar do autor ter usado apenas um valor para a cama de frango, foi encontrado como menor e maior TIR 5,0 e 13,5\% ao ano. Na presente pesquisa o menor e maior valor gerado foi de 14,37 e 19,87\% ao ano. Dada a instabilidade econômica vivenciada pelo país entre 1991 e principalmente meados de 1994 e, com uma elevada taxa de inflação, fica dificil comparar estes resultados, no sentido de avaliar se existiu uma melhoria na rentabilidade do investimento feito pelo produtor integrado.

Contrastando entre si os resultados das TIRs das tabelas 07, 08, 09 e 10 com o objetivo de comparar os contratos, observa-se que o contrato A apresentou o menor retorno potencial ao capital investido, uma vez que a máxima TIR de retorno gerada, considerando apenas o valor médio para a cama de frango, foi de $14,5 \%$ ao ano. Para este mesmo valor, a probabilidade de ser gerada uma taxa igual ou superior é de $100 \%$ nos contratos B, C e D.

Para o contrato A, existe uma grande concentração de TIRs entre 12,00 e $13,50 \%$ ao ano, com $87,8 \%$ de probabilidade de ocorrência. Apesar da baixa amplitude de variação para a TIR, a rentabilidade do investimento torna-se delicada sob condições de risco, quando comparada à maior taxa de custo médio ponderado do capital de $13,7 \%$ ao ano. 
O contrato B por outro lado, mesmo em condições de risco não mostrou problemas para tornar-se viável. A menor TIR gerada é superior ao maior CMPC em questão. Os resultados concentram-se entre 16,89 e 19,39\% ao ano com uma probabilidade de $71,3 \%$ de ocorrerem. Ressalte-se no entanto a grande dispersão encontrada para os resultados.

O contrato $\mathrm{C}$, apesar de terem sido geradas TIRs menores que o CMPC de $13,7 \%$ ao ano, e com grande dispersão dos resultados, é um contrato com elevado potencial de viabilidade, mesmo em condições de risco. Os resultados concentram-se no intervalo de 15,59 a 19,59\% ao ano, com uma probabilidade de ocorrência de $60 \%$.

$\mathrm{O}$ contrato $\mathrm{D}$, em relação aos contratos $\mathrm{B}$ e $\mathrm{C}$, foi o que mostrou a menor dispersão dos resultados, e isto é bom, desde que os valores gerados sejam maiores que o custo médio ponderado do capital. Neste caso, $83,36 \%$ dos resultados concentram-se entre 15,87 e $18,87 \%$ ao ano.

A partir da análise feita anteriormente algumas inferências podem ser feitas. O método de simulação permitiu avaliar que sob as mesmas condições de tecnologia e guardadas as características de cada produtor, quando os contratos são analisados sob condições de risco, o contrato A revelou ter o menor retorno potencial ao investimento. Os contratos B e C, geraram uma elevada amplitude entre a menor e maior taxa interna de retorno, mas em ambos os casos concentraram-se no mesmo patamar com bom retorno potencial. $O$ contrato $D$ apesar da pequena dispersão entre os extremos, também tem o potencial de viabilidade praticamente igual aos contratos B e C.

No trabalho de Lopes (1992), o autor chegou à conclusão que os contratos que utilizavam o preço de mercado como balizador para o preço pago ao produtor, tinham o maior potencial de retorno ao investimento. Na presente pesquisa esta conclusão não pode ser tirada, uma vez que os contratos A e B, que utilizam-se do preço APA, geraram resultados bem distintos. Por utilizar apenas duas variáveis técnicas no cálculo do índice alcançado pelo produtor, o contrato A pode estar penalizando-o por variações que ficam a cargo da empresa, como por exemplo idade de abate. Neste caso, deve existir sempre uma padronização do tempo de alojamento para que, principalmente 
a variável conversão alimentar não seja muito afetada. Desta forma, sob condições de incerteza e dependendo do custo médio ponderado do capital, o contrato $A$, dentro da proposta do trabalho, revela uma atividade com elevados riscos de viabilidade econômica.

Tentando fazer um paralelo entre a organização dos produtores, localização geográfica e os resultados encontrados, pode-se dizer que: os contratos B e C são praticados na mesma região, por empresas com um potencial relativamente elevado de produção, haja vista a capacidade de abate e, podem potencialmente concorrer entre si pelos produtores e pelo mesmo mercado. Não existe organização dos produtores em associações no caso do contrato $\mathrm{C}$ mas, a empresa iniciou o processo de integração contratual muito recentemente, podendo este quadro mudar para o futuro. Estes fatores podem estar contribuindo para a semelhança dos resultados encontrados. Mesmo com as diferenças entre os extremos gerados para as TIRs, os dois contratos têm praticamente o mesmo bom retorno potencial ao investimento. Neste caso, fica claro que mantidas as fórmulas de remuneração, o compromisso das empresas em suprir os galpões com gás e mão-de-obra para a apanha dos frangos deve prevalecer.

No caso do contrato $\mathrm{D}$, acredita-se que a organização dos produtores esteja contribuindo para o bom retorno potencial do investimento uma vez que, a planilha de custo dos produtores é feita de comum acordo com a integradora. O que chama a atenção no caso deste contrato e também do contrato $\mathrm{C}$, é a utilização no cálculo do índice, da eficiência técnica média da integração. É necessário neste caso, que exista sempre uma dispersão entre os resultados alcançados pelos produtores, ou seja, para que o integrado tẻnha um retorno positivo é preciso que ele permaneça sempre acima da média.

Neste ponto é que o valor da cama de frango deve ser avaliado. $O$ investimento mostrou-se muito sensível a variações no valor da cama de frango e, caso haja uma expansão da produção que provoque uma queda em seu preço, a atividade apresenta sérios problemas para tornar-se viável economicamente, independente da fórmula de remuneração a que o produtor está submetido, caso seja mantido o mesmo pacote tecnológico. 
Assim, a conscientização dos produtores para fazerem um consorciamento da atividade avícola com outras que possam utilizar a cama de frango como esterco ou ração animal é muito pertinente. Se a cama for utilizada apenas para a comercialização e, como não é permitido a reutilização da mesma em diversos lotes, os produtores devem ficar atentos para a possibilidade de inviabilidade do investimento. 


\section{CAPÍTULO IV - RESUMO E CONCLUSÃO}

A avicultura de corte no Brasil, devido ao crescente avanço tecnológico, tem apresentado um dos maiores aumentos de produção e produtividade dentro do setor agropecuário, colocando a avicultura brasileira entre as mais desenvolvidas do mundo. Um dos principais fatores responsáveis por este desempenho foi a rápida absorção dos avanços tecnológicos alcançados por países de avicultura desenvolvida, por meio da importação de linhagens de alta produtividade que, aliada a um manejo eficiente, permitiu melhor conversão alimentar e maior ganho de peso diário, diminuindo de forma significativa o tempo de engorda das aves.

$\mathrm{O}$ avanço tecnológico na produção avícola foi acompanhado por uma reestruturação do sistema produtivo, que entre outras mudanças proporcionadas ao meio rural, alterou a forma de produção, integrando-a verticalmente através de contratos.

A produção avicola coordenada contratualmente disseminou-se prontamente no Estado de Santa Catarina a partir de 1960, onde não havia uma avicultura moderna em bases comerciais, como havia em São Paulo e Minas Gerais. A produção avícola mineira diferentemente dos Estados do sul e até mesmo de São Paulo, que, no final da década de 70, já havia esboçado o movimento de integrar a produção das granjas aos abatedouros, desenvolveu-se no sistema de produção independente altamente pulverizada com grande participação de pequenos produtores avícolas.

A crise vivenciada pelo setor avícola no início dos anos 80 , levantou a questão de readaptação da estrutura de produção em Minas Gerais, que poderia caminhar para as duas vertentes ao mesmo tempo: tanto o fortalecimento da verticalização como a implantação da integração vertical sob contratos ou coordenação contratual. 
O sistema de produção baseado no coordenação contratual foi amplamente incentivado pela EMATER/MG, como solução para os pequenos produtores. Teve-se então no final de 1980 a implantação deste sistema de produção por uma empresa localizada na Zona da Mata, com cerca de oitenta (80) produtores.

Apesar da produção integrada sob contratos em Minas Gerais ser relativamente recente, ela tem se tornado uma opção de atividade para pequenos e médios produtores, uma vez que pode ser conduzida com exigências mínimas de área e mão-de-obra, originando receita em um periodo relativamente curto. Por outro lado, elevados índices de eficiência técnica estão direta e indiretamente relacionados com uma considerável inversão de capital fixo. Nestas circunstâncias, os produtores investem na atividade considerando um horizonte temporal relativamente longo que envolve incerteza.

Existem diferentes contratos no complexo avicola mineiro e, todos levam em consideração determinadas variáveis técnicas tais como: taxa de mortalidade, conversão alimentar, ganho de peso diário, entre outras, para remunerarem os produtores. As diferenças básicas destes contratos dizem respeito exatamente na forma de determinação da remuneração.

Levando-se em consideração estes aspectos, definiu-se como objetivo geral deste trabalho, a análise econômica dos contratos de integração praticados no Estado de Minas Gerais, no sentido de avaliar a viabilidade econômica do investimento feito pelo produtor integrado sob diferentes contratos e fórmulas de remuneração, introduzindo a variável incerteza. Também fez parte dos objetivos, levantar a participação da produção integrada sob contratos do Estado e sua distribuição espacial.

Considerou-se como fonte de incerteza todas as variáveis técnicas usadas na determinação da remuneração. Para cada contrato foi calculado o índice utilizado pela empresa na fórmula de remuneração. $O$ preço do quilo de frango vivo cotado pela Associação Paulista de Avicultura - APA, também constitui-se em fonte de risco, uma vez que é utilizado em dois contratos, como balizador do preço a ser pago ao produtor.

O projeto avaliado neste trabalho diz respeito aos gastos necessários para a construção e operacionalização de um galpão de $1200 \mathrm{~m}^{2}$, com capacidade de alojar até 14.000 aves. Dada a grande importância da cama de frango neste sistema de produção, a 
avaliação do investimento foi feita com diferentes valores para a mesma, com o intuito de medir a sensibilidade do projeto a variações no valor da cama de frango, dado o mesmo nível de eficiência técnica.

A partir das teorias de análise econômica de projetos, na qual a técnica de simulação de Monte Carlo permite a análise de incerteza, calculou-se a taxa interna de retorno (TIR) como indicador para avaliar a viabilidade econômica. $\mathrm{O}$ método de simulação para o cálculo da TIR foi feita por meio de um programa específico para cada contrato, utilizando o Microsoft Execel 5.0.

Obtidos os resultados e feitas as análises, chegou-se às seguintes conclusões:

i) Apesar da produção avícola integrada contratualmente no Estado de Minas Gerais ser relativamente recente e participar com apenas $41,26 \%$ da capacidade produtiva do Estado, existe uma tendência para o crescimento da sua participação. Em número de produtores, $67,32 \%$ estão submetidos a este sistema.

Esta tendência ao crescimento da participação da produção contratual na avicultura de corte mineira, revela-se pelo crescente aumento do número de produtores neste sistema, e o caminho seguido pelos principais Estados produtores, principalmente os do Sul do pais. Nestes, em quase sua totalidade a produção comercial de frango de corte está sob coordenação contratual. Ocorrendo o mesmo no Estado de São Paulo, que de acordo com Zirlis et al. (1990), tem $78 \%$ da produção integrada contratualmente. Outro fator, é a própria opinião dos representantes do setor avícola mineiro, que unanimemente nas entrevistas, mostraram acreditar que este é o caminho a ser seguido pela avicultura de corte no Estado de Minas Gerais;

ii)Este sistema de produção mostrou a possibilidade de participação de produtores com capacidade de alojamento relativamente baixa, uma vez que a capacidade média dos integrados é de apenas 13.834 aves, comparado ao dos independentes e/ou cooperados que é de 48.796. As demais exigências de maneira geral dizem respeito à racionalidade econômica do ponto de vista das empresas, estabelecendo-se uma distância mínima das granjas aos abatedouros e/ou fábricas de ração; 
iii) De maneira geral, as empresas afirmam ter entrado no sistema de coordenação contratual devido à tendência de mercado, matéria-prima assegurada e homogênea, aumento de produtividade, e redução de necessidade de investimento;

iv) A produção integrada do Estado mostrou-se bem concentrada em termos regionais. As empresas estão localizadas em apenas três regiões, com concentração de produtores nas regiões da Zona da Mata e Triângulo Mineiro, com respectivamente 48,11 e $39,14 \%$ do total de produtores integrados contratualmente;

v) Outro ponto que merece ser destacado é a grande participação das empresas que trabalham com a coordenação contratual na capacidade de abate sob inspeção federal. Apesar de participarem com menor capacidade produtiva, estas empresas têm abatedouros fiscalizados pelo serviço de inspeção federal, com $60,37 \%$ da capacidade de abate sob inspeção federal do Estado;

vi) Quanto às cláusulas contratuais, todos os contratos analisados são bem semelhantes. É muita clara a posição que o produtor assume diante do sistema de produção. Cabe à empresa integradora toda a tomada de decisão em relação aos insumos a serem utilizados, tais como: ração, pintos de um dia e assistência técnica, ficando a cargo do produtor os gastos na construção do galpão e despesas operacionais para mantê-lo em funcionamento. Como também, a condução do manejo prescrito pela empresa integradora;

viii) $\mathrm{O}$ que difere basicamente os contratos é a maneira de se estabelecer o preço a ser pago ao produtor. Em dois contratos ( $\mathrm{A}$ e $\mathrm{B}$ ), as fórmulas estabelecem a partir dos coeficientes técnicos o quanto caberá ao produtor em quilo de ave viva. $O$ total em quilo é multiplicado pelo preço do quilo de frango cotado pela APA, estabelecendo desta forma a parte do produtor. Os outros dois contratos (C e D), utilizam-se de fórmulas que já fornecem o que caberá ao produtor em valor monetário.

Em dois contratos ( $\mathrm{B}$ e $\mathrm{C}$ ), existe também uma cláusula em que as empresas comprometem-se a cobrir os gastos com o gás e apanha do frangos. Para o produtor, isto torna-se interessante por que, mesmo as empresas embutindo este custo nas fórmulas, o avicultor livra-se da necessidade deste capital de giro. Cabe, no entanto salientar, que esta cláusula foi inclú́da no contrato B, como um artifício encontrado pela 
empresa para tentar melhorar a remuneração, não sendo no entanto, uma cláusula permanente;

ix) Quanto à viabilidade econômica, os resultados da simulação mostraram que mesmo sob condições de risco e, levando-se em consideração apenas o valor médio para a cama de frango, em maior ou menor grau os contratos garantem aos produtores uma atratividade para o capital investido. Apesar das diferenças matemáticas das fórmulas de remuneração, em três contratos, a taxa interna de retorno concentrou-se praticamente nos mesmos intervalos, quais sejam, contrato $B, 16,89$ a $19,89 \%$ ao ano com probabilidade de $79,5 \%$, contrato $C, 15,09$ a $19,59 \%$ ao ano, com $73,5 \%$ de probabilidade e o contrato $\mathrm{D}, 15,87$ a $18,87 \%$ ao ano com $92 \%$ de probabilidade de ocorrência. Isto revela que, mesmo utilizando-se de práticas como por exemplo, pagamento do gás e apanha do frango nos contratos $\mathrm{B}$ e $\mathrm{C}$ e pagamento do fundo de depreciação no contrato $\mathrm{D}$, as fórmulas de remuneração geram praticamente as mesmas taxas internas de retorno. Para o contrato $\mathrm{A}$, a maior concentração foi nos intervalos de 12,50 a $13,50 \%$ ao ano, com uma probabilidade de ocorrência de $87,8 \%$.

Comparando com os três diferentes custos médios ponderados do capital e utilizando-se do valor médio para a cama de frango, apenas um dos contratos mostrou-se deficitário do ponto de vista de viabilidade econômica, mesmo quando comparado ao maior CMPC, dentro da proposta do trabalho. De maneira geral, os contratos de integração analisados garantem uma certa estabilidade de renda ao produtor, remunera os fatores de produção e potencialmente propiciam uma renda residual.

O que preocupa na análise destes contratos é a sensibilidade do investimento às variações no valor da cama de frango. Não é possível a nenhum dos contratos tornar o investimento economicamente viável se não for dado à cama de frango algum valor monetário. Isto revela que dado um pacote tecnológico e mantidas as caracteristicas de cada produtor, um menor ou maior retorno ao investimento depende, além dos índices alcançados, da utilização da cama de frango na própria propriedade, aumentando desta forma a renda ou da sua comercialização no mercado.

Estes resultados mostram que, se por um lado a coordenação contratual na produção avícola viabiliza a participação de pequenos produtores no processo produtivo 
ao eliminar o problema de escala, comercialização e mais ainda, não sendo necessário a este produtor o capital de giro para a compra dos insumos ração e pintos de um dia, por outro lado, surge o problema da comercialização da cama de frango.

Isto mostra que a viabilidade do investimento, independente do contrato e fórmula de remuneração a que estão submetidos os produtores integrados, está intimamente relacionada ao valor de venda da cama de frango. 


\section{REFERÊNCIAS BIBLIOGRÁFICAS}

ALVES, E. R. A. A agroindústria e os agricultores. Brasilia: CODEVASP, 1988. $29 \mathrm{p}$.

ALVES FILHO, E. (coord.) Análise das transformações no processo de produção avícola através dos contratos de integração em Minas Gerais: relatório de pesquisa financiada pela FAPEMIG. Viçosa: UFV, 1993. 123p.

AVES E OVOS, São Paulo, v. 11, n. 11, set. 1995.98 p.

AVES E OVOS, São Paulo, v. 12, n. 5, mar. 1996. 34 p.

ANUÁRIO ESTATÍSTICO DO BRASIL - Rio de Janeiro, v. 53, 3 - 57 p, 1993.

AZEVEDO FILHO, A. J.B. V. Análise econômica de projetos: "software" para situações determinísticas e de risco envolvendo simulação. Piracicaba, 1988. 127p. Dissertação (Mestrado) - Escola Superior de Agricultura "Luiz de Queiroz", Universidade de São Paulo.

BANCO DE DESENVOLVIMENTO DO ESTADO DE SÃO PAULO. Agroindústria e desenvolvimento no Estado de São Paulo: relações contratuais de compra e venda de produtos agrícolas. São Paulo: BADESP, 1978. v.1, 26p.

BARROS, G. S. C. Economia da comercialização agrícola. Piracicaba: FEALQ,1987. $306 \mathrm{p}$.

BELATO, D. Cadeias agroalimentares e a agropecuária integrada ou de contrato. Contexto e Educação, v.1, n. 1, p. 60-73, 1986.

BELATO, D. A subordinação do camponês no interior das cadeias agroalimentares: integração e contratos de produção. Contexto e Educação, v.1, n. 2, p. 61-80, 1986a. 
CONTADOR, C. R. Avaliação social de projetos. São Paulo: Atlas, 1981. 301p.

DeGroOT, M. H. Probality and Statistics. 2. ed. California Addison Wesley, 1986. $716 \mathrm{p}$.

FUNDAÇÃO GETÚLIO VARGAS. Conjuntura estatística: encarte. Conjuntura Econômica, v. 50, n. 4, 1 -51 p., abr. 1996.

KING, R. P. Management and financing of vertical coordination in agriculture: an overview. American Journal of Agricultural Economics, v. 74, n. 5, 1217 - 1218 p. Dec. 1992.

GUIMARÃES, V. D. A. Comercialização e transmissão de preços de carne de frango no Estado de São Paulo. Piracicaba, 1990. 119p. Dissertação (Mestrado) - Escola Superior de Agricultura "Luiz de Queiroz", Universidade de São Paulo.

LATÁPIA, M. X. I. C. Custo de produção agrícola sob condições de risco no Estado de São Paulo. Piracicaba, 1988. 57p. Dissertação (Mestrado)- Escola Superior de Agricultura "Luiz de Queiroz", Universidade de São Paulo.

LOPES, J. E. P. Análise econômica de contratos de integração usados no complexo agroindustrial avícola brasileiro. Viçosa, 1992. 104 p. Dissertação (Mestrado) Universidade Federal de Viçosa.

MARQUES, P. V. Economia da integração vertical na avicultura de corte do Estado de São Paulo. Piracicaba, 1991. 132p. Tese (Livre Docência) - Escola Superior de Agricultura 'Luiz de Queiroz”, Universidade de São Paulo.

NORONHA, J. F. O sistema de avaliação econômica de projetos agropecuários na política brasileira de crédito rural. Piracicaba, 1982. 120p. Tese (Livre Docência) Escola Superior de Agricultura 'Luiz de Queiroz", Universidade de São Paulo.

NORONHA, J. F. Projetos Agropecuários - administração financeira: orçamento e viabilidade econômica. 2. ed. São Paulo: Atlas, 1987. 269p.

HOFFMANN, R. Estatísticas para economistas. 2. ed. São Paulo: Livraria Pioneira Editora, 1991. 426p.

ROY, E. P. Contract farming and economic integration. Danville, The Interstate Printer, 1972. 
SÁ, J. M. Análise econômica da engorda de bovinos em confinamento em Goiás. Piracicaba, 1985. 95p. Dissertação (Mestrado) - Escola Superior de Agricultura “Luiz de Queiroz", Universidade de São Paulo.

SANDRONI, P. Dicionário de Economia. São Paulo, Abril Cultural. 1985.

SAS INSTITUTE INC. SAS procedure guide - version 6, 3. ed. Cary, 1990. 705p.

SHIROTA, R. ; SILVA, R.D.M. Avaliação econômica comparativa de matriz de duas linhagens de frango para corte. Piracicaba: FEALQ, 1985. 29p. (Relatório de Pesquisa).

SORJ, B. ; POMPERMAYER, M. J. ; CORADINI, O L. Camponeses e agroindústria: transformação social e representação política na avicultura. Rio de Janeiro: Zahar, 1982. 118p.

THAME, A. C. M. ; AMARO, A. A. Formas de organização em comercialização agrícola. In:CONGRESSO BRASLLEIRO DE ECONOMIA E SOCIOLOGLA RURAL, 20. Curitiba, 1982. Anais. Curitiba:SOBER, v. 1, 595p. 1982.

WILLIAMSON, O. E. Las instituiciones económicas del capitalismo. México: Fondo de Cultura Económica, 1989 . 436p.

WOILER, S. ; MATHIAS, W. F. Projetos: planejamento, elaboração e análise. São Paulo: Atlas, 1986. 294p.

ZIRLIS,. A. E. F. ; LINS, E. R.; GIULIETTI, N. et al. Integração vertical, custos e receitas na avicultura de corte no Estado de São Paulo. Agricultura em São Paulo, v. 37, n. $3,147-173$ p. 1990. 


\section{APÊNDICE 1}

\section{CONTRATO A}

\section{INSTRUMENTO PARTICULAR DE CONTRATO DE PARCERIA PECUÁRIA}

Pelo presente instrumento de contrato de parceria pecuária, de um lado, , doravante designada simplesmente INTEGRADORA; e de outro lado doravante designado simplesmente AVICULTOR; tem entre si justo e contratado a presente Parceria Pecuária, nos seguintes termos:

\section{I - DO OBJETO:}

Artigo $1^{\circ}-O$ presente contrato de parceria, tem por objetivo a criação de frangos de corte, de propriedade da INTEGRADORA, nas instalações do AVICULTOR, alojados em galpões da granja

\section{II - DO IMÓVEL}

Artigo $2^{\circ}$ - As instalações do AVICULTOR, onde serão criados os frangos, estão localizadas no imóvel de sua propriedade, cadastrado no INCRA sob o $n^{\circ}$ situado no

\section{III - DO PRAZO}

Artigo $3^{\circ}$ - O presente contrato terá a duração de 6 (seis) meses a contar da data da sua assinatura, podendo ser renovado automaticamente, por igual período, toda vez que a INTEGRADORA remeter ao AVICULTOR um novo lote de pintos de um dia para criar, mantidos os mesmos artigos e condições deste contrato.

Parágrafo $1^{\circ}$ - Não havendo o procedimento previsto neste artigo pela INTEGRADORA ao término do prazo contratual, o mesmo será considerado automaticamente rescindido, independente de aviso ou notificação.

Parágrafo $2^{\circ}$ - Não havendo interesse do AVICULTOR em renovar o presente contrato, deverá notificar por escrito, à INTEGRADORA dessa sua intenção, até 30 (TRINTA) dias antes do término do prazo contratual.

IV - DAS OBRIGAÇÕES DO AVICULTOR

Artigo $4^{\circ}$ - O AVICULTOR se obriga a: 
01 - Proceder conforme as instruções da INTEGRADORA, a limpeza e desinfecção dos galpões e equipamentos, deixando-os em ordem, para receber os pintos de um dia na data em que estiver programada a entrega dos mesmos; ficando sujeito à aprovação prévia por equipe de inspeção designada pela INTEGRADORA; adequando o número de equipamentos à quantidade de pintos a serem criados conforme determinado pela INTEGRADORA.

02 - Prestar os serviços necessários a manejar os galpões e equipamentos, durante toda a criação das aves, tudo conforme instrução da INTEGRADORA;

03 - Dar livre acesso a INTEGRADORA e seus representantes legais a todas as instalações, com a finalidade de inspeção das aves sob criação; não permitir visitas de estranhos sem permissão da INTEGRADORA.

05 - Proceder a descarga e guarda das raçōes, medicamentos e vacinas, de modo seguro, eficiente e adequado, de forma a proceder a devolução à INTEGRADORA, dos produtos não utilizados que estejam em sua embalagem original, ainda fechadas, e em perfeito estado quanto à qualidade, indicando os produtos não utilizados que não se apresentem nestas condições;

06 - Utilizar as rações, medicamentos, vacinas remetidos para a criação prevista neste contrato, exclusivamente para este fim;

07 - Manter em perfeito estado e funcionamento todos os equipamentos e instalações da granja que de algum modo influam na criação objeto de parceria;

08 - Estar presente quando da entrega dos pintos de um dia e retirada das aves responsabilizando-se pelo recebimento dos pintos junto ao veículo transportador, e pela apanha e entrega das aves, também junto ao veículo transportador;

09 - Avisar a INTEGRADORA, imediatamente (dentro de 02 horas) quando da constatação de qualquer eventualidade que possa atingir o desenvolvimento normal da criação, como por exemplo, doenças;

10 - Manter os acessos aos galpões e à área de carregamento de aves vivas transitável a caminhões pesados para transporte de rações e/ou aves vivas; inclusive estradas municipais não asfaltadas, mobilizando-se junto às prefeituras do seu município; 
11 - Manter atualizados os controles do desenvolvimento da criação, conforme instruções da INTEGRADORA;

12 - Contar e remover as aves mortas, segundo as normas complementares fornecidas pela INTEGRADORA;

13 - Deixar aves em jejum alimentar nas 08 (oito) horas que antecedem a do carregamento do lote;

14 - Fornecer mão-de-obra adequada e suficiente para o carregamento das aves vivas na data prevista para a retirada;

15 - Atender a todas as recomendações técnicas da INTEGRADORA;

16 - Fornecer a cama e o gás necessários para a criação, de acordo com as especificações técnicas da INTEGRADORA, revertendo o respectivo esterco ao AVICULTOR;

\section{V - DAS OBRIGAÇÕES DA INTEGRADORA:}

Artigo $5^{\circ}$ - A INTEGRADORA se obriga a:

01 - Escolher e/ou adquirir os pintos de um dia, medicamentos e vacinas a serem utilizadas na criação;

02 - Programar e avisar o AVICULTOR da data em que ocorrerá a entrega dos pintos de um dia na granja, com 07 (sete) dias de antecedência, procedendo à inspeção do local; cada lote será alojado em um galpão, de acordo com sua capacidade e receberá numeração em ordem crescente para cada INTEGRADO;

03 - Reprogramar a entrega dos pintos de um dia, caso a sua equipe técnica considere não estar o estabelecimento em condições de recebê-los;

04 - Provar durante todo o desenvolvimento do lote, a ração, medicamento, vacinas, bem como prestar a assistência técnica e veterinária que se fizer necessária;

05 - Avisar com antecedência, o dia e hora em que se considerará terminada a criação, e, em consequiência, proceder a retirada das aves. Esta data será aproximadamente entre o $42^{\circ}$ (quadragésimo segundo) e $48^{\circ}$ (quadragésimo oitavo) dia após o início da criação; 
06 - Ao término da criação de cada lote, receberá em devolução sem computar no custo retro-citado, a ração do lote, desde que tais produtos estejam em sua embalagem original ainda fechadas, e em perfeito estado quanto à qualidade;

07 - Fornecer os veículos e as gaiolas necessárias para o transporte dos frangos, após o término do período de criação;

08 - A INTEGRADORA reserva-se o direito de alterar, a seu critério, a tabela de remuneração do INTEGRADO DE ACORDO com as condições de mercado, bastando para isto informar ao INTEGRADO antes do alojamento do lote subsequente.

\section{VI - DA REMUNERAÇÃo}

Artigo $6^{\circ}$ - Caberá ao AVICULTOR, à título de remuneração, uma participação calculada sobre o peso dos frangos entregues, de acordo com a conversão alimentar, nos termos da tabela anexa (supracitada), que fica sendo sua parte integrante para todos os efeitos.

Parágrafo $1^{\circ}$ - No caso de terem as condenações do SIF - Serviço de Inspeção Federal do Ministério da Agricultura e Abatedouro, peso superior a 0,5\% do peso total e esta condenação ser decorrente de negligência de manejo por parte do AVICULTOR, comprovado pelo SIF, todo o peso condenado será suportado pelo AVICULTOR.

Artigo $7^{\circ}$ - A conversão alimentar será obtida através do cálculo entre a quantidade de ração consumida, o montante de carne produzida; a condenação e mortalidade de cada lote. Teremos como base de cálculo a cotação da APA (Associação Paulista de Avicultura), vigente na semana do abate.

Parágrafo $1^{\circ}-O$ cálculo da quantidade de carne produzida será efetuado mediante peso vivo das aves na portaria do ABATEDOURO .Fica a INTEGRADORA autorizada a proceder um desconto de $5 \%$ no peso total do lote, caso seja desrespeitado o jejum alimentar prévio e as aves tiverem ração no papo.

Parágrafo $2^{\circ}$ - $\mathrm{O}$ pagamento será efetuado 15 dias após o abate das aves.

\section{VII - DO INADIMPLEMENTO}

Artigo $8^{\circ}$ - $\mathrm{O}$ inadimplemento de quaisquer das disposições do presente contrato, sujeitará o faltoso à multa igual a 0,10 Obrigações do Tesouro Nacional, ou por 
outra forma que venha substituir a Obrigação do Tesouro Nacional na data do seu pagamento, por unidade de pinto entregue, acrescida de custas judiciais e honorários de advogado à razão de $20 \%$ (vinte por cento), se houver necessidade de recurso ao Poder Judiciário.

Artigo $9^{\circ}$ - O AVICULTOR representará como garantia neste ato, uma Nota Promissória correspondente ao total do lote, no valor estimado do custo no período do alojamento, emitida em favor da INTEGRADORA.

\section{VIII - DO FORO:}

Artigo $10^{\circ}$ - Os contratantes elegem o foro da comarca de com renuncia de qualquer outro por mais privilegiado que for, para dirimir qualquer dúvida oriunda do presente contrato.

Por estarem justos e contratados, as partes firmam o presente instrumento em 02 (duas) vias de igual teor, para um só efeito, obrigando-se por si seus herdeiros e sucessores, ao bom e fiel cumprimento deste contrato.

, de de 19

\section{TESTEMUNHAS:}


TABELA - CONVERSÃO ALIMENTAR

\begin{tabular}{|l|lll|r|}
\hline PESO & \multicolumn{2}{|l|}{ CONVERSÃO } & $\%$ \\
VIVO & ALIMENTAR & & \\
\cline { 2 - 4 } & ATÉ & & 1.900 & 12.00 \\
& 1.901 & $\mathrm{a}$ & 1.915 & 11.50 \\
& 1.916 & $\mathrm{a}$ & 1.930 & 11.00 \\
& 1.931 & $\mathrm{a}$ & 1.945 & 10.50 \\
& 1.946 & $\mathrm{a}$ & 1.960 & 10.00 \\
& 1.961 & $\mathrm{a}$ & 1.975 & 9.50 \\
$\mathrm{ATÉ}$ & 1.976 & $\mathrm{a}$ & 1.990 & 9.00 \\
& 1.991 & $\mathrm{a}$ & 2.005 & 8.50 \\
& 2.006 & $\mathrm{a}$ & 2.020 & 8.00 \\
& 2.021 & $\mathrm{a}$ & 2.035 & 7.50 \\
& 2.036 & $\mathrm{a}$ & 2.050 & 7.00 \\
& 2.051 & $\mathrm{a}$ & 2.065 & 6.50 \\
& 2.066 & $\mathrm{a}$ & 2.080 & 6.00 \\
& 2.081 & $\mathrm{a}$ & 2.095 & 5.50 \\
& 2.096 & $\mathrm{a}$ & 2.110 & 5.00 \\
$1.800 \mathrm{~g}$ & 2.111 & $\mathrm{a}$ & 2.125 & 4.50 \\
& 2.126 & $\mathrm{a}$ & 2.140 & 4.00 \\
\hline
\end{tabular}

\begin{tabular}{|l|lll|r|}
\hline $\begin{array}{l}\text { PESO } \\
\text { VIVO }\end{array}$ & $\begin{array}{l}\text { CONVERS } \tilde{A} O \\
\text { ALIMENTAR }\end{array}$ & $\%$ \\
\hline & ATE & & 1.930 & 12.00 \\
& 1.931 & $\mathrm{a}$ & 1.945 & 11.50 \\
& 1.946 & $\mathrm{a}$ & 1.960 & 11.00 \\
& 1.961 & $\mathrm{a}$ & 1.975 & 10.50 \\
& 1.976 & $\mathrm{a}$ & 1.990 & 10.00 \\
& 1.991 & $\mathrm{a}$ & 2.005 & 9.50 \\
& 2.006 & $\mathrm{a}$ & 2.020 & 9.00 \\
$1.801 \mathrm{~g}$. & 2.021 & $\mathrm{a}$ & 2.035 & 8.50 \\
& 2.036 & $\mathrm{a}$ & 2.050 & 8.00 \\
& 2.051 & $\mathrm{a}$ & 2.065 & 7.50 \\
& 2.066 & $\mathrm{a}$ & 2.080 & 7.00 \\
$\mathrm{~A}$ & 2.081 & $\mathrm{a}$ & 2.095 & 6.50 \\
& 2.096 & $\mathrm{a}$ & 2.110 & 6.00 \\
& 2.111 & $\mathrm{a}$ & 2.125 & 5.50 \\
& 2.126 & $\mathrm{a}$ & 2.140 & 5.00 \\
$1.900 \mathrm{~g}$. & 2.141 & $\mathrm{a}$ & 2.155 & 4.50 \\
& 2.156 & $\mathrm{a}$ & 2.170 & 4.00 \\
\hline
\end{tabular}

\begin{tabular}{|l|lll|r|}
\hline PESO & \multicolumn{2}{|l|}{ CONVERSÄO } & & $\%$ \\
VIVO & ALIMENTAR & & \\
\hline & ATÉ & & 1.960 & 12.00 \\
& 1.961 & $\mathrm{a}$ & 1.975 & 11.50 \\
& 1.976 & $\mathrm{a}$ & 1.990 & 11.00 \\
& 1.991 & $\mathrm{a}$ & 2.005 & 10.50 \\
& 2.006 & $\mathrm{a}$ & 2.020 & 10.00 \\
& 2.021 & $\mathrm{a}$ & 2.035 & 9.50 \\
& 2.036 & $\mathrm{a}$ & 2.050 & 9.00 \\
$1.901 \mathrm{~g}$. & 2.051 & $\mathrm{a}$ & 2.065 & 8.50 \\
& 2.066 & $\mathrm{a}$ & 2.080 & 8.00 \\
& 2.081 & $\mathrm{a}$ & 2.095 & 7.50 \\
& 2.096 & $\mathrm{a}$ & 2.110 & 7.00 \\
$\mathrm{~A}$ & 2.111 & $\mathrm{a}$ & 2.125 & 6.50 \\
& 2.126 & $\mathrm{a}$ & 2.140 & 6.00 \\
& 2.141 & $\mathrm{a}$ & 2.155 & 5.50 \\
& 2.156 & $\mathrm{a}$ & 2.170 & 5.00 \\
$2.000 \mathrm{~g}$. & 2.171 & $\mathrm{a}$ & 2.185 & 4.50 \\
& 2.186 & $\mathrm{a}$ & 2.200 & 4.00 \\
\hline
\end{tabular}

\begin{tabular}{|l|lll|l|}
\hline PESO & CONVERSÃO & & $\%$ \\
\hline VIVO & ALIMENTAR & & \\
\hline & ATÉ & & 1.990 & 12.00 \\
& 1.991 & $\mathrm{a}$ & 2.005 & 11.50 \\
& 2.006 & $\mathrm{a}$ & 2.020 & 11.00 \\
& 2.021 & $\mathrm{a}$ & 2.035 & 10.50 \\
& 2.036 & $\mathrm{a}$ & 2.050 & 10.00 \\
& 2.051 & $\mathrm{a}$ & 2.065 & 9.50 \\
& 2.066 & $\mathrm{a}$ & 2.080 & 9.00 \\
$2.001 \mathrm{~g}$ & 2.081 & $\mathrm{a}$ & 2.095 & 8.50 \\
& 2.096 & $\mathrm{a}$ & 2.110 & 8.00 \\
& 2.111 & $\mathrm{a}$ & 2.125 & 7.50 \\
& 2.126 & $\mathrm{a}$ & 2.140 & 7.00 \\
$\mathrm{~A}$ & 2.141 & $\mathrm{a}$ & 2.155 & 6.50 \\
& 2.156 & $\mathrm{a}$ & 2.170 & 6.00 \\
& 2.171 & $\mathrm{a}$ & 2.185 & 5.50 \\
& 2.186 & $\mathrm{a}$ & 2.200 & 5.00 \\
$2.100 \mathrm{~g}$. & 2.201 & $\mathrm{a}$ & 2.215 & 4.50 \\
& 2.216 & $\mathrm{a}$ & 2.230 & 4.00 \\
\hline
\end{tabular}

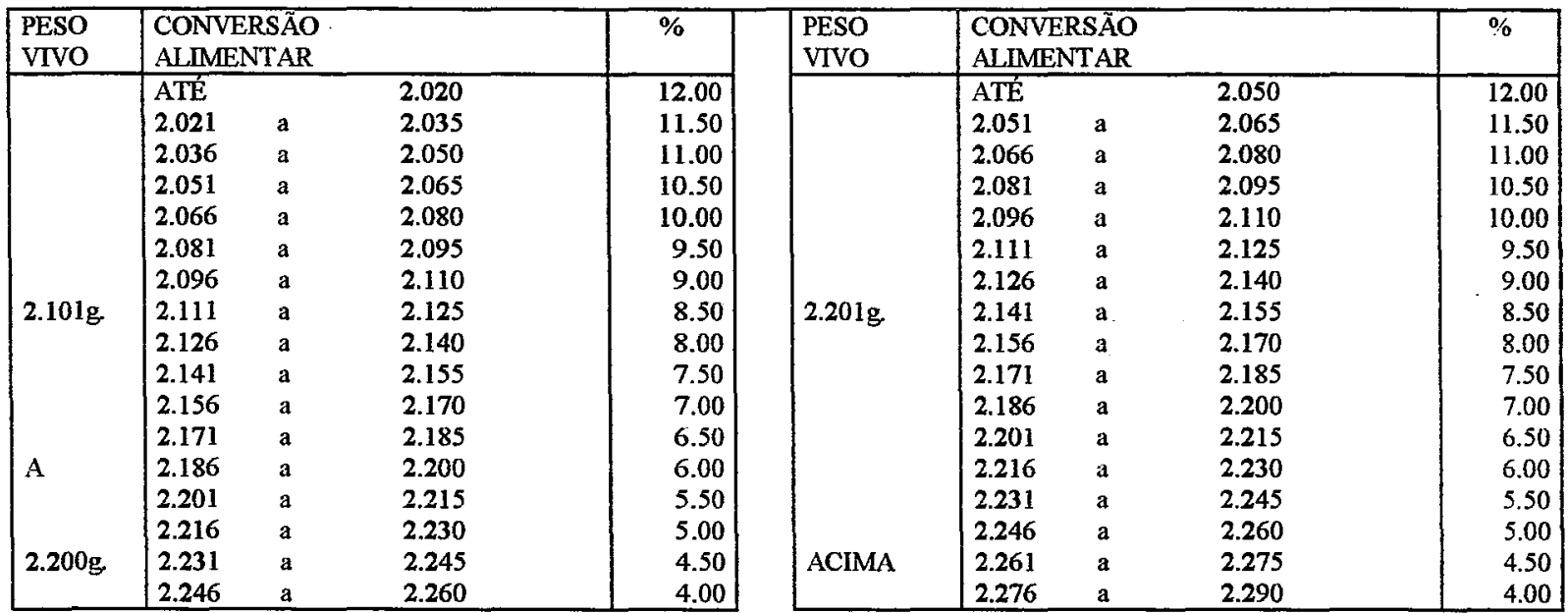




\section{APÊNDICE 1}

\section{CONTRATO B}

\section{CONTRATO DE PARCERIA AVICOLA}

Pelo presente instrumento particular de contrato, de um lado proprietária das aves (pintos de um dia), de ração, de medicamentos e de insumos, doravante denominada PARCEIRA PROPRIETÁRIA, e doravante denominado PARCEIRO CRIADOR, tem justo e contratado a presente PARCERIA AVÍCOLA, que se regerá pela Legislação Agrária, Código Civil e Cláusulas seguintes:

CLÁUSULA $1^{\mathrm{a}}$ - PARCEIRA PROPRIETÁRIA se obriga a entregar ao PARCEIRO CRIADOR, na sua propriedade pintos de um dia, para serem criados e terminados.

Parágrafo Único: Os Pintos acima mencionados, são objetos, exclusivamente do presente contrato de parceria avícola, não podendo ser desviados para outros fins, até a partilha final.

CLÁUSULA $2^{\mathrm{a}}$ - A PARCEIRA PROPRIETÁRIA, para fins de criação e terminação das aves, fornecerá as rações, assistência técnica e medicamentos necessários para a criação e engorda das mesmas, devendo o PARCEIRO CRIADOR solicitar o suprimento e administrar o consumo de acordo com as necessidades ou prescrições.

Parágrafo Único - Os insumos acima referidos são destinados, unicamente, para criação e terminação das aves descritas na cláusula $2^{\mathrm{a}}$.

CLÁUSULA $3^{\mathrm{a}}$ - Após a entrega das aves terminadas, a reposição para cada aviário de pintos de um dia e de ração inicial, será efetuada no prazo que está descrito e explicitado no ANEXO CONTRATUAL, o que deverá conter, obrigatoriamente, as assinaturas das partes, e que integra o presente contrato para todos os fins de direito; podendo esse prazo ser dilatado mediante a cientificação por escrito ao PARCEIRO CRIADOR, com as razões especificadas, havendo superveniência de força maior que impeça o cumprimento do aqui exposto, inclusive por problema de ordem sanitária que vierem a ocorrer no aviário, atestado pelo departamento técnico da PARCEIRA PROPRIETÁRIA.

Parágrafo Único: Poderá a PARCEIRA PROPRIETÁRIA dilatar o prazo a que se refere o (caput) desta cláusula se: 
1 - Após uma primeira advertência por escrito, constatar através de seus técnicos, que o PARCEIRO CRIADOR, é reincidente na aplicação de manejo contrário a boa técnica e que o resultado obtido com o lote de aves tenha sido prejudicado em virtude do manejo adotado. Caso ocorram resultados de lote abaixo da média de resultados de toda a integração, por motivos do responsável pela granja a PARCEIRA PROPRIETÁRIA notificará por escrito. Em reincidência, sem o devido atendimento às sugestões solicitadas, o PARCEIRO CRIADOR poderá ter suspenso na primeira vez o alojamento por 01 (um) lote, em nova ocorrência suspensão por 02 (dois) lotes e após a terceira suspensão, o cancelamento automático do CONTRATO sem ônus à PARCEIRA PROPRIETÁRIA.

2 - Constatar que as instalações do aviário não oferecem condições de alojamento inclusive por falta de equipamento necessário.

CLÁUSULA $4^{\mathrm{a}}$ - O PARCEIRO CRIADOR dispensará cuidados necessários e indispensáveis para a criação e terminação das aves, adotando para tanto, os procedimentos técnicos que melhor se recomenda, facultando-se-lhe sem qualquer ônus, buscar junto ao Departamento de Fomento da PARCEIRA PROPRIETÁRIA, a orientação técnica e veterinária que esta dispensa à sua própria criação.

CLÁUSULA $5^{\mathrm{a}}$ - Uma vez completado o período de criação e engorda das aves, respeitada a partilha prevista na CLÁUSULA 6a, a parte pelo PARCEIRO CRIADOR, cujo transporte correrá por conta daquela.

CLÁUSULA $6^{\mathrm{a}}$ - Do resultado obtido na criação e engorda das aves, o PARCEIRO CRIADOR terá direito a título de participação na PARCERIA, a uma parcela das aves vivas produzidas, da qual poderá dispor. Esta parcela é calculada sobre o total em quilos do lote, pesado no abatedouro da PARCEIRA PROPRIETÁRIA, conforme fórmula e tabela para esse fim existente, das quais ambos os PARCEIROS declaram expressamente terem pleno conhecimento, e onde serão observados os critérios de cálculo de eficiência da produção.

Parágrafo $1^{\mathrm{o}}$ : A fórmula e tabela acima mencionada estão descritas e explicitadas no ANEXO CONTRATUAL, o qual deverá conter, obrigatoriamente, as assinaturas das partes, e que integra o presente contrato para todos os fins de direito.

Parágrafo $2^{\circ}$ : Caso interesse ao PARCEIRO CRIADOR, a PARCEIRA PROPRIETÁRIA se compromete a adquirir a parte deste, pelo preço 
estabelecido pela cotação da APA correndo o frete por conta da PARCEIRA PROPRIETÁRIA tendo esta um prazo em dias para efetuar o pagamento, conforme ANEXO CONTRATUAL. Neste caso a PARCEIRA PROPRIETÁRIA terá sempre a preferência para a aquisição, sendo que a pesagem e abate das aves somente poderá ocorrer nas instalações da PARCEIRA PROPRIETÁRIA.

CLÁUSULA 7a: A PARCEIRA PROPRIETÁRIA se obriga a entregar ao PARCEIRO CRIADOR todos os "tickets" de pesagem das aves entregues, facultando-lhe o direito de acompanhar as pesagens no estabelecimento de destino das mesmas.

CLÁUSULA 8: Por ocasião da entrega das aves, a sobra de ração que eventualmente ocorrer, que é de propriedade da PARCEIRA PROPRIETÁRIA, será transferida a outro criador, assim como poderá ficar na propriedade do PARCEIRO CRIADOR, para outro frete, a critério da PARCEIRA PROPRIETÁRIA.

CLÁUSULA 9a: As despesas ocorridas com os serviços de manejo e cuidados com as aves e a cama do aviário, correrão por conta exclusiva do PARCEIRO CRIADOR, que se obriga a fornecer toda a mão-de-obra necessária, sua e/ou de terceiros, respondendo pelos encargos sociais e/ou trabalhista previstos em lei.

CLÁUSULA 10á É facultado a PARCEIRA PROPRIETÁRIA, acompanhar a criação e engorda das aves, para o que é assegurado livre e permanente acesso as instalações nas quais o plantel está sendo terminado.

CLÁUSULA 11 $1^{\text {a }}$ : O prazo de duração do presente contrato é indeterminado, podendo o mesmo ser rescindido por qualquer das partes mediante notificação por escrito com antecedência mínima de $10(\mathrm{dez})$ dias, não gerando esta medida qualquer direito à indenização para qualquer das partes.

O PARCEIRO CRIADOR, terá o seu contrato imediatamente cancelado, sem qualquer direito à indenização ou aviso antecipado, caso ocorra conduta de má fé com os itens objeto deste contrato, ou o previsto na CLÁUSULA $3^{a}$ Parágrafo Único item 1.

CLÁUSULA 12a: O inadimplemento das obrigações assumidas por qualquer das partes dará lugar facultativamente a rescisão do contrato, respondendo o inadimplente pelas perdas e danos que causar. 
CLÁUSULA 13 ${ }^{\mathrm{a}}$. Fica eleito o fórum da Comarca de para qualquer ação fundada neste contrato.

E assim por estarem justos e contratados, assinam o presente instrumento em três vias iguais teor e forma, na presença das testemunhas abaixo, sendo a terceira via destinada ao Cartório de Registro de Títulos e Documentos para os devidos fins.

PARCEIRO PROPRIETÁRIO

\section{PARCEIRO CRIADOR}

\section{TESTEMUNHAS:}

1.

Nome:

$\mathrm{CPF}$ :

2.

Nome:

CPF:

3.

Nome:

$\mathrm{CPF}$ :

4.

Nome:

$\mathrm{CPF}$ : 


\section{ANEXO AO CONTRATO DE PARCERIA AVÍCOLA}

Fórmula para determinação da parcela do PARCEIRO CRIADOR no(s) lote(s) de frangos produzidos:

$$
\text { PPCk }=\frac{\text { (APA X PER X KGS }}{\text { APA }}
$$

NOTAS:

a) Significado das abreviações:

PPCk = Parcela do Parceiro Criador em Kgs

APA = Cotação da APA no dia do abate em $R \$ p / K g$

PER $=$ Percentual obtido conforme aplicado da fórmula e tabela a seguir

KGS $=$ Total em quilos do lote, pesado no abatedouro da Parceira Proprietária.

b) Desta fórmula resulta diretamente a parcela a que terá direito o PARCEIRO CRIADOR, sobre o total de kgs produzidos no(s) lote(s) de frangos.

IEP = ÍNDICE DE EFICIÊNCIA E PRODUTIVIDADE

$$
\text { IEP }=\frac{\text { PESO MEDIO } \times \text { VIABILIDADE }}{\text { CONVERSAO ALIMENTAR } \times \text { IDADE }} \times 100
$$

\begin{tabular}{|llll|}
\hline \multicolumn{3}{c}{ IEP } & $(\%)$ \\
\hline até & & 219,50 & 7,00 \\
219,51 & a & 221,50 & 7,50 \\
221,51 & a & 223,50 & 7,85 \\
223,51 & a & 225,50 & 8,20 \\
225,01 & a & 227,50 & 8,55 \\
227,01 & a & 229,50 & 8,90 \\
229,01 & a & 231,50 & 9,25 \\
231,01 & a & 233,50 & 9,60 \\
233,01 & a & 235,50 & 9,95 \\
235,01 & a & 237,50 & 10,30 \\
237,01 & a & 239,50 & 10,70 \\
239,01 & a & 241,50 & 11,10 \\
241,01 & a & 243,50 & 11,50 \\
243,01 & a & 245,50 & 11,95 \\
245,01 & a & 247,50 & 12,47 \\
247,01 & a & 249,50 & 12,85 \\
249,01 & a & 251,50 & 13,30 \\
\hline
\end{tabular}

\begin{tabular}{|cccc|}
\hline \multicolumn{3}{|c|}{ IEP } & (\%) \\
\hline 251,51 & a & 253,50 & 13,75 \\
253,51 & a & 255,50 & 14,20 \\
255,51 & a & 257,50 & 14,65 \\
257,51 & a & 259,50 & 15,10 \\
259,51 & a & 261,50 & 15,55 \\
261,51 & a & 263,50 & 16,00 \\
263,51 & a & 265,50 & 16,45 \\
265,51 & a & 267,50 & 16,90 \\
267,51 & a & 269,50 & 17,35 \\
269,51 & a & 271,50 & 17,80 \\
271,51 & a & 273,50 & 18,30 \\
273,51 & a & 275,50 & 18,80 \\
275,51 & a & 277,50 & 19,30 \\
277,51 & a & 279,50 & 19,80 \\
279,51 & a & 281,50 & 20,30 \\
281,51 & a & 283,50 & 20,80 \\
283,51 & & acima & 21,30 \\
\hline
\end{tabular}


Caso ocorra alguma negligência por parte do PARCEIRO CRIADOR, comprovada, causando transtorno e ou prejuizo a PARCEIRA PROPRIETÁRIA, poderá ocorrer descontos de ressarcimento.

A PARCEIRA PROPRIETÁRIA alojará nas instalações do PARCEIRO CRIADOR, de 08 (oito) a 12 (doze) pintos de um dia por $\mathrm{m}^{2}$, conforme CLÁUSULA $1^{\mathrm{a}}$ e Parágrafo Único.

A reposição para cada aviário de pinto de um dia e de ração inicial será efetuada num prazo médio de 15 (quinze) dias, conforme CLÁUSULA $3^{\mathrm{a}}$ Parágrafo Único Itens 1 e 2.

Sendo interesse do PARCEIRO CRIADOR vender a parte que the cabe na PARCERIA, a PARCEIRA PROPRIETÁRIA terá um prazo de (10) dez dias corridos para efetuar o pagamento, conforme CLÁUSULA $6^{\text {a }}$ Parágrafo $2^{\circ}$.

A PARCEIRA PROPRIETÁRIA concederá como adicional sobre a parcela obtida pelo PARCEIRO CRIADOR, nas despesas ocorridas com: aquecimento e pega das aves, cabendo ao PARCEIRO CRIADOR toda a responsabilidade na aquisição de itens necessários ao aquecimento, bem como contratar se necessário for a equipe de pega das aves, acompanhar e seguir as orientações de como proceder a pega das aves de acordo com as recomendações da PARCEIRA PROPRIETÁRIA.

Objetivando premiar o bom manejo e desempenho do PARCEIRO CRIADOR a PARCEIRA PROPRIETÁRIA, concederá em função da baixa mortalidade, um adicional sobre a parcela obtida pelo PARCEIRO CRIADOR, conforme tabela abaixo:

PERCENTUAL DE MORTALIDADE bônus em percentagem em relação a parte que couber ao parceiro criador em kgs.

$\begin{array}{llll}\text { até } & & 2,00 & 10 \\ 2,01 & \text { à } & 2,75 & 05 \\ 2,76 & \text { à } & 3,25 & 02 \\ 3,26 & \text { acima } & & 00\end{array}$

PARCEIRO PROPRIETÁRIO

PARCEIRO CRIADOR 


\section{APÊNDICE 1}

\section{CONTRATO C}

FÓRMULA DE REMUNERAÇÃO

$\mathrm{FP}=\frac{\mathrm{GPD} * \text { Viabilidade }}{\mathrm{CA}} * 10$

$\mathrm{FP}=$ fator de produtividade

GPD = ganho de peso diário

Viabilidade $=100 \%$ - Taxa de Mortalidade

$\mathrm{CA}=$ conversão alimentar

Alíquota $=9 \%+(\mathrm{FP}-\mathrm{FP}$ médio $) * 0,2$

REMUNERAÇÃO $=$ Alíquota $*$ Peso Total Entregue * 0,7

Os produtores submetidos a este contrato recebem o gás necessário ao aquecimento das aves bem como a apanha das mesmas.

De um modo geral, segundo o responsável pelo setor de integração desta empresa, as cláusulas contratuais não diferem muito dos outros contratos.

A empresa se obriga a fornecer pintos de boa qualidade, ração, medicamentos e toda a assistência técnica e veterinária que se faz necessária ao bom desenvolvimento das aves. Da mesma forma que nos outros contratos é explícito que o produtor integrado é apenas um fiel depositário dos insumos que lhes são entregue.

$O$ integrado fornece toda a instalação devidamente equipada para a engorda dos frangos, bem como, mão-de-obra necessária ao manejo, cabendo a ele todas as obrigações de ordem trabalhista.

O contrato é por tempo indeterminado desde que ambas as partes cumpram com as normas pré-estabelecidas. 


\section{APÊNDICE 1}

\section{CONTRATO D}

\section{Instrumento Particular de Contrato de Participação em Produção Integrada de Frango de Corte}

Pelo presente instrumento particular de contrato de participação em produção integrada de frango de corte de um lado, como indústria integradora, doravante designada simplesmente "TNDÚSTRIA", e, de outro lado como produtor integrado,

$\mathrm{CPF}$ :

\section{IPR:}

doravante designado simplesmente "INTEGRADO", têm entre si, justo, combinado e, afinal, contratados, o que se expõe nas cláusulas e condições seguintes, que mutuamente, aceitam e outorgam.

$1^{\mathrm{a}}$ - O "INTEGRADO", em sua propriedade e instalações, localizadas em:

a partir da as-

sinatura deste contrato, se obriga a criar e produzir para a "INDÚSTRIA", com absoluta exclusividade, frangos de corte dentro dos padrões de que abaixo se fala:

$2^{\mathrm{a}}$ - O presente contrato é celebrado pelo prazo de um ano, a contar de sua assinatura, ficando certo e ajustado que esse prazo se prolongará automaticamente até que todo(s) o(s) plantel(eis) de aves atinja, a exclusivo critério da "INDÚSTRIA", a idade ideal para o abate, com o que desde já concorda e aquiesce o "INTEGRADO". $O$ contrato se reconduzirá, automaticamente, por igual período, caso qualquer uma das partes não o denunciar expressamente e por escrito, com a antecedência mínima de 60 (sessenta) dias do seu término ou dos períodos subsequentes;

$3^{\mathrm{a}}$ - O "TNTEGRADO", dentro de sua capacidade instalada constante da Ficha de Inscrição por ele assinada, se obriga a manter seus galpões sempre em plena produção, de forma que estes nunca fiquem ociosos durante o prazo contratual;

$4^{\mathrm{a}}$ - A "INDÚSTRIA", para cada lote de frangos a ser criado, se obriga a fornecer ao "INTEGRADO", posto no local, todos os insumos, quais sejam: pintos de primeira qualidade, ração, medicamentos necessários e indispensáveis ao tratamento e criação 
dos plantéis de aves, objeto do presente contrato, que, obrigatoriamente, deverão ser colocados em lugares apropriados, não se admitindo seu extravio em hipótese alguma, sendo entregues, e aplicados mediante fichas de controle, nas quais serão anotados os vistos pelo "TNTEGRADO", seus prepostos ou empregados, à cada verificação;

$5^{\mathrm{a}}$ - Ao "INTEGRADO", caberá fornecer energia, água, material para a cama e todas as instalações apropriadas, constantes de galinheiros, galpões abrigo, utensílios e acessórios e indispensáveis para a criação e tratamento de pintos de um (1) dia e frangos de corte, cabendo-lhe ainda a administração por si, prepostos ou empregados devidamente habilitados, ficando sob sua responsabilidade exclusiva todas e quaisquer implicações de ordem social, trabalhista e previdenciária pertinentes e referentes a vínculos empregatícios;

$6^{\mathrm{a}}$ - O "INTEGRADO", se obriga à, retirada do lote de frangos, desinfetar imediatamente os galpões e prepará-los para, dentro do prazo máximo de 10 (dez) dias de sua desocupação, receber o novo lote de pintos para criar;

$7^{\mathrm{a}}$ - A "INDÚSTRIA" efetuará fiscalização permanente no local de criação, seja diretamente, seja por preposto ou funcionário, regrando o conduzimento racional do(s) plantel(eis), fornecendo por escrito ao "INTEGRADO", seus prepostos ou empregados, as normas técnicas a serem rigorosamente empregadas, para maior rendimento da criação, ficando desde logo acertada, a inteira subordinação do "INTEGRADO" na adoção imediata das normas técnicas impostas evitando risco do empreendimento, respondendo civel e criminalmente omissão;

$8^{\mathrm{a}}$ - O pagamento da "INDÚSTRIA" ao "INTEGRADO" se fará mediante o que for apurado no acerto feito de acordo com o PROGRAMA GERAL DE PONTOS em anexo que, rubricado pelas partes, fica fazendo parte integrante do presente contrato;

Parágrafo Primeiro - Cada ponto corresponderá a R\$ 0,0004438 (valor de fev. de 1996), valor este que será corrigido de acordo com as partes;

Parágrafo Segundo - O peso final do lote de frangos a ser considerado, bem como o número final de aves, será aquele que se verificar no abatedouro da "INDÚSTRIA".

Parágrafo Terceiro - O esterco ficará pertencendo ao "INTEGRADO" como valor fixo devido pela "INDÚSTRIA".

Parágrafo Quarto - A pontuação adotada como mínima, será de 80 (OITENTA) pontos, e a performance do "INTEGRADO" abaixo desse limite importará na perda do esterco para a "INDÚSTRIA". 
$9^{\mathrm{a}}$ - O pagamento será efetuado ao "INTEGRADO", no máximo, dentro de 15 (QUINZE) dias seguintes à data da retirada das aves;

$10^{\mathrm{a}}$ - A apanha e o engradamento das aves na ocasião da saída do lote deverá ser efetuada pelo "INTEGRADO" e seu prepostos, com o cuidado de proteger as aves de contusões e mortalidades. As aves deverão ficar sem alimento desde 6 horas antes do horário programado para o abate.

\section{$11^{\mathrm{a}}$ - VACINAÇÃO CONTRA NEWCASTLE.}

A vacinação ou não, fica a critério exclusivo da "INDÚSTRIA".

$12^{\mathrm{a}}$ - O "INTEGRADO" se declara FIEL DEPOSITÁRIO de todas as aves e insumos que lhe forem entregues e confiados pela "INDÚSTRIA", sujeito às sanções legais, não podendo, assim, deles dispor, bem como retirar aves do(s) plantel(eis) em qualquer idade e para quaisquer fins excetuando-se nos casos em que a técnica o exigir, que deverá ser anotado nas fichas próprias para posterior conhecimento da "INDÚSTRIA".

$13^{a}$ - O "INTEGRADO", franqueará à "INDÚSTRIA", ou a seus prepostos ou funcionários autorizados, o livre ingresso na área onde se localizam os galpões e acessórios utilizados para a criação objeto do presente contrato, sempre que solicitado e necessário se tornar, seja para o ingresso no plantel, da rações, medicamentos em geral e implementos outros referentes ao setor de atividade objeto do presente contrato. Por outro lado, obriga-se o "INTEGRADO" a evitar, seja por aceiros, cêrcas ou isolamento, aproximação de animais outros estranhos no plantel, até mesmo por aves não pertencentes ao mesmo plantel, responsabilizando-se isoladamente pelas conseqüências que a omissão e negligência provocar;

$14^{\mathrm{a}}$ - O presente contrato se rescindirá: a) por vontade das partes, no prazo e forma da cláusula segunda $\left(2^{\mathrm{a}}\right)$; b) pelo não cumprimento de quaisquer de suas cláusulas e condições; c) por deficiência técnica no manejo e condução do plantel; d) por desobediência às normas e orientação técnicas ditadas; e) pela não aplicação de ingredientes básicos e rações, na forma prescrita e instituídas da cláusula sétima $\left(7^{\mathrm{a}}\right)$.

$15^{\mathrm{a}}$ - As normas técnicas de que se trata na cláusula sétima e, as posteriores alterações que se fizerem sentir no correr da criação dos planteis, e, por conseqüência exclusivas destes, ficam desde logo fazendo parte integrante do presente contrato, e, não poderão ser invocados como base as desobediências ou novação do ora pactuado no presente contrato;

$16^{a}$ - A parte que infringir qualquer cláusula deste contrato sujeitar-se-á ao pagamento, de uma indenização correspondente a 100 (CEM) vezes do salário referência vigente no país; 
$17^{\mathrm{a}}$ - As partes contratantes se obrigam por si, seus herdeiros ou sucessores, elegendo, desde logo, o fórum , com exclusão de qualquer outro, por mais privilegiado que seja para dirimir as dúvidas e questões oriunda e decorrentes deste contrato.

E por estarem assim justos e contratados, assinam o presente instrumento particular em 3 (TRÊS) vias de igual teor e forma e para um só efeito, com as testemunhas abaixo.

de de 19

"INDÚSTRIA"

"INTEGRADO"

TESTEMUNHAS:

$1^{\mathrm{a}}$

$2^{\mathrm{a}}$ 
ANEXO 1

Tabela de Pontuação

A - Mortalidade

\begin{tabular}{|c|c|c|c|c|c|c|c|c|c|c|}
\hline $\begin{array}{c}\% \\
\text { MORTALIDADE }\end{array}$ & 0,7 & 0,8 & 0,9 & 1,0 & 1,1 & 1,2 & 1,3 & 1,4 & 1,5 & 1,6 \\
\hline No PONTOS & 79 & 76 & 73 & 70 & 67 & 64 & 61 & 58 & 55 & 52 \\
\hline $\begin{array}{c}\% \\
\text { MORTALIDADE }\end{array}$ & 1,7 & 1,8 & 1,9 & 2,0 & 2,1 & 2,2 & 2,3 & 2,4 & 2,5 & 2,6 \\
\hline No PONTOS & 49 & 46 & 43 & 40 & 38 & 36 & 34 & 32 & 30 & 28 \\
\hline $\begin{array}{c}\% \% \\
\text { MORTALIDADE } \\
\end{array}$ & 2,7 & 2,8 & 2,9 & 3,0 & 3,1 & 3,2 & 3,3 & 3,4 & 3,5 & 3,6 \\
\hline No PONTOS & 26 & 24 & 22 & 20 & 19 & 18 & 17 & 16 & 15 & 14 \\
\hline $\begin{array}{c}\% \\
\text { MORTALIDADE } \\
\end{array}$ & 3,7 & 3,8 & 3,9 & 4,0 & 4,1 & 4,2 & 4,3 & 4,4 & 4,5 & 4,6 \\
\hline No PONTOS & 13 & 12 & 11 & 10 & 8 & 6 & 4 & 2 & 0 & -2 \\
\hline $\begin{array}{c}\% \\
\text { MORTALIDADE }\end{array}$ & 4,7 & 4,8 & 4,9 & 5,0 & 5,1 & 5,2 & 5,3 & 5,4 & 5,5 & 5,6 \\
\hline No PONTOS & -4 & -6 & -8 & -10 & -13 & -16 & -19 & -22 & -25 & -28 \\
\hline $\begin{array}{c}\% \\
\text { MORTALIDADE }\end{array}$ & 5,7 & 5,8 & 5,9 & 6,0 & 6,1 & 6,2 & 6,3 & 6,4 & 6,5 & 6,6 \\
\hline No PONTOS & -31 & -34 & \begin{tabular}{|l|}
-37 \\
\end{tabular} & -40 & -43 & -46 & -49 & -52 & -55 & -58 \\
\hline $\begin{array}{c}\% \\
\text { MORTALIDADE } \\
\end{array}$ & 6,7 & 6,8 & 6,9 & 7,0 & 7,1 & 7,2 & 7,3 & 7,4 & 7,5 & 7,6 \\
\hline No PONTOS & \begin{tabular}{|l|}
-61 \\
\end{tabular} & -64 & \begin{tabular}{|l|}
-67 \\
\end{tabular} & -70 & -73 & -76 & -79 & -82 & -85 & -88 \\
\hline $\begin{array}{c}\% \\
\text { MORTALIDADE } \\
\end{array}$ & 7,7 & 7,8 & 7,9 & 8,0 & 8,1 & 8,2 & 8,3 & 8,4 & 8,5 & 8,6 \\
\hline No PONTOS & -91 & -94 & -97 & $\begin{array}{c}- \\
100 \\
\end{array}$ & \begin{tabular}{|c|}
- \\
103 \\
\end{tabular} & $\begin{array}{c}- \\
106 \\
\end{array}$ & -109 & -112 & -115 & -118 \\
\hline $\begin{array}{c}\% \\
\text { MORTALIDADE } \\
\end{array}$ & 8,7 & 8,8 & 8,9 & 9,0 & 9,1 & 9,2 & 9,3 & 9,4 & 9,5 & 9,6 \\
\hline No PONTOS & \begin{tabular}{|c|}
- \\
121 \\
\end{tabular} & - & -127 & - & \begin{tabular}{|c|} 
\\
133 \\
\end{tabular} & - & -139 & -142 & -145 & -148 \\
\hline $\begin{array}{c}\% \\
\text { MORTALIDADE }\end{array}$ & 9,7 & 9,8 & 9,9 & 10 & 10,1 & 10,2 & 10,3 & 10,4 & 10,5 & 10,6 \\
\hline No PONTOS & \begin{tabular}{|c|}
- \\
151 \\
\end{tabular} & - & \begin{tabular}{|c|}
- \\
157 \\
\end{tabular} & \begin{tabular}{|c|} 
\\
160 \\
\end{tabular} & \begin{tabular}{|c|} 
\\
163 \\
\end{tabular} & \begin{tabular}{|c|} 
\\
166 \\
\end{tabular} & -169 & -172 & -175 & -178 \\
\hline $\begin{array}{c}\% \\
\text { MORTALIDADE }\end{array}$ & 10,7 & 10,8 & 10,9 & 11,0 & 12,0 & & & & & \\
\hline No PONTOS & \begin{tabular}{|c|}
- \\
181 \\
\end{tabular} & $\begin{array}{c}- \\
184 \\
\end{array}$ & $\begin{array}{c}- \\
187\end{array}$ & - & 300 & & & & & \\
\hline
\end{tabular}


B - Conversão Alimentar

\begin{tabular}{|l|l|l|l|l|l|l|l|l|l|l|}
\hline $\begin{array}{l}\text { CONVERSÃO } \\
\text { ALIMENTAR }\end{array}$ & 1,8 & 1,81 & 1,82 & 1,83 & 1,84 & 1,85 & 1,86 & 1,87 & 1,88 & 1,89 \\
\hline No PONTOS & 247 & 238 & 229 & 220 & 211 & 202 & 193 & 184 & 175 & 167 \\
\hline $\begin{array}{l}\text { CONVERSÃO } \\
\text { ALIMENTAR }\end{array}$ & 1,9 & 1,92 & 1,93 & 1,94 & 1,95 & 1,96 & 1,97 & 1,98 & 1,99 & 2,00 \\
\hline No PONTOS & 158 & 149 & 140 & 131 & 122 & 113 & 104 & 101 & 098 & 095 \\
\hline $\begin{array}{l}\text { CONVERSÃO } \\
\text { ALIMENTAR }\end{array}$ & 2,01 & 2,02 & 2,03 & 2,04 & 2,05 & 2,06 & 2,07 & 2,08 & 2,09 & 2,10 \\
\hline No PONTOS & 088 & 085 & 082 & 080 & 077 & 075 & 072 & 070 & 067 & 065 \\
\hline $\begin{array}{l}\text { CONVERSÃO } \\
\text { ALIMENTAR }\end{array}$ & 2,11 & 2,12 & 2,13 & 2,14 & 2,15 & 2,16 & 2,17 & 2,18 & 2,19 & 2,20 \\
\hline No PONTOS & 062 & 059 & 056 & 053 & 049 & 046 & 037 & 028 & 019 & 010 \\
\hline $\begin{array}{l}\text { CONVERSÃO } \\
\text { ALIMENTAR }\end{array}$ & 2,21 & 2,22 & 2,23 & 2,24 & 2,25 & 2,26 & 2,27 & 2,28 & 2,29 & 2,30 \\
\hline No PONTOS & 001 & -8 & -17 & -26 & -35 & -44 & -53 & -62 & -71 & -80 \\
\hline $\begin{array}{l}\text { CONVERSÃO } \\
\text { ALIMENTAR }\end{array}$ & 2,31 & 2,32 & 2,33 & 2,34 & 2,35 & 2,36 & 2,37 & 2,38 & 2,39 & 2,40 \\
\hline No PONTOS & -89 & -98 & -107 & -116 & -125 & -134 & -143 & -152 & -161 & -170 \\
\hline $\begin{array}{l}\text { CONVERSÃO } \\
\text { ALIMENTAR }\end{array}$ & 2,41 & 2,42 & 2,43 & 2,44 & 2,45 & 2,46 & 2,47 & 2,48 & 2,49 & 2,5 \\
\hline No PONTOS & -179 & -188 & -197 & -206 & -215 & -224 & -233 & -242 & -251 & -260 \\
\hline
\end{tabular}

C - Ganho de

Peso Diário

\begin{tabular}{|l|l|l|l|l|l|l|l|l|l|l|}
\hline $\begin{array}{l}\text { GANHO PESO } \\
\text { DIÁRIO (Gr) }\end{array}$ & 62,0 & 61,5 & 61,0 & 60,5 & 60,0 & 59,5 & 59,0 & 58,5 & 57,5 & 57,0 \\
\hline No PONTOS & 433 & 423 & 413 & 403 & 393 & 383 & 373 & 363 & 353 & 333 \\
\hline GPD & 56,5 & 55,5 & 55,0 & 54,5 & 54,0 & 53,5 & 53,0 & 52,5 & 52,0 & 51,5 \\
\hline No PONTOS & 323 & 313 & 303 & 293 & 283 & 273 & 263 & 253 & 243 & 233 \\
\hline GPD & 51,0 & 50,5 & 50,0 & 49,5 & 49,0 & 48,5 & 48,0 & 47,5 & 47,0 & 46,5 \\
\hline No PONTOS & 223 & 213 & 203 & 193 & 187 & 181 & 175 & 169 & 163 & 157 \\
\hline GPD & 46,0 & 45,5 & 45,0 & 44,5 & 44,0 & 43,5 & 43,0 & 42,5 & 42,0 & 41,5 \\
\hline No PONTOS & 151 & 145 & 140 & 135 & 130 & 125 & 120 & 115 & 110 & 105 \\
\hline GPD & 41,0 & 40,5 & 40,0 & 39,5 & 39,0 & 38,5 & 38,0 & 37,5 & 37,0 & 36,5 \\
\hline No PONTOS & 099 & 093 & 087 & 081 & 075 & 069 & 063 & 057 & 047 & 037 \\
\hline GPD & 36,0 & 35,5 & 35,0 & 34,5 & 34,0 & 33,5 & 33,0 & 32,5 & 32,0 & 31,5 \\
\hline No PONTOS & 027 & 017 & 007 & -3 & -13 & -23 & -33 & -43 & -53 & -63 \\
\hline GPD & 30,5 & 30,0 & & & & & & & & \\
\hline No PONTOS & -83 & -93 & & & & & & & & \\
\hline
\end{tabular}


D - Contusão

$$
\begin{gathered}
\% \\
0 \text { - --- 1,3 } \\
1,4 \text {---- 1,7 } \\
1,8 \text {---- 2,2 } \\
\text { Acima de 2,3 }
\end{gathered}
$$$$
\text { No PONTOS }
$$$$
10,0
$$$$
6,5
$$$$
3,5
$$$$
0,0
$$

E - Tempo de Carregamento

\begin{tabular}{|c|c|c|c|c|c|}
\hline TEMPO & 30 Min & 40 Min & 50 Min & 60 Min & Acima \\
\hline No PONTOS & 10 & 6,0 & 4,0 & 2,0 & 0 \\
\hline
\end{tabular}

F - Manejo

\begin{tabular}{|c|c|c|c|}
\hline ÓTIMO & BOM & REGULAR & RUIM \\
\hline 10 & 6,0 & 4,0 & 0 \\
\hline
\end{tabular}




\section{APÊNDICE 2}

QUADRO 2.1 - Fluxo de Caixa do Projeto de Investimento para o Contrato A (valores em R\$ de fevereiro de 1996)

\begin{tabular}{lrr}
\hline Discriminação & \multicolumn{1}{c}{ Ano 1 } & \multicolumn{1}{c}{ Ano 15} \\
\hline A- Entradas & & \\
1 - Entrega do Frangos * & 9386,08 & 10743,39 \\
2 - Venda da Cama de Frango & 5348,70 & 6418,44 \\
3 - Valor Residual & - & 9275,17 \\
& & \\
B- Saídas & & \\
1 - Investimento & 37100,70 & - \\
2 - Custo Operacional & & \\
2.1 - Material para Cama & 1855,95 & 2227,14 \\
2.2 - Conservação de Equipamentos & 781,08 & 781,08 \\
2.3 - Conservação do Galpão & 429,60 & 429,60 \\
2.4 - Mão - de- obra Manejo + Encargos & 3469,40 & 4163,28 \\
2.5 - Mão-de-obra para Apanha & 553,85 & 664,62 \\
2.6 - Medicamentos para Desinfecção & 75,00 & 90,00 \\
2.7 - Gás & 3150,00 & 3780,00 \\
2.8 - Energia Elétrica & 640,70 & 768,84 \\
2.9 - Alimentação c/ Pessoal da Apanha & 300,00 & 360,00 \\
\hline Fluxo Líquido (A - B) & $-33621,50$ & 13172,44 \\
\hline
\end{tabular}

* Valores Simulados 


\section{APÊNDICE 2}

QUADRO 2.2 - Fluxo de Caixa do Projeto de Investimento para o Contrato B (valores em R $\$$ de fevereiro de 1996)

\begin{tabular}{lrr}
\hline Discriminação & \multicolumn{1}{c}{ Ano 1 } & \multicolumn{1}{c}{ Ano 15 } \\
\hline A- Entradas & & \\
1 - Entrega do Frangos * & 6645,64 & 8265,20 \\
2 - Venda da Cama de Frango & 5348,70 & 6418,44 \\
3 - Valor Residual & - & 9275,17 \\
& & \\
B- Saídas & & \\
1 - Investimento & 37100,70 & - \\
2 - Custo Operacional & & \\
2.1 - Material para Cama & 1855,95 & 2227,14 \\
2.2 - Conservação de Equipamentos & 781,08 & 781,08 \\
2.3 - Conservação do Galpão & 429,60 & 429,60 \\
2.4 - Mão-de- obra Manejo + Encargos & 3469,40 & 4163,28 \\
2.5 - Medicamentos para Desinfeç̧ão & 75,00 & 90,00 \\
2.7 - Energia Elétrica & 640,70 & 768,84 \\
2.8 - Alimentação c/ pessoal da Apanha & 300,00 & 360,00 \\
2.9 - Despesa com Associação & 95,71 & 114,20 \\
\hline Fluxo Líquido (A - B) & $-32753,80$ & 15024,64
\end{tabular}

* Valores Simulados 


\section{APÊNDICE 2}

QUADRO 2.3 - Fluxo de Caixa do Projeto de Investimento para o Contrato C (valores em R \$ de fevereiro de 1996)

\begin{tabular}{lrr}
\hline Discriminação & \multicolumn{1}{c}{ Ano 1 } & \multicolumn{1}{c}{ Ano 15 } \\
\hline A- Entradas & 10349,88 & \\
1 - Entrega do Frangos * & 5348,70 & 9601,13 \\
2 - Venda da Cama de Frango & - & 6418,44 \\
3 - Valor Residual & & 9275,17 \\
& & \\
B- Saídas & 37100,70 & \\
1 - Investimento & & - \\
2 - Custo Operacional & 1855,95 & 2227,14 \\
2.1 - Material para Cama & 781,08 & 781,08 \\
2.2 - Conservação de Equipamentos & 429,60 & 429,60 \\
2.3 - Conservação do Galpão & 3469,40 & 4163,28 \\
2.4 - Mão-de- obra Manejo + Encargos & 75,00 & 90,00 \\
2.5 - Medicamentos para Desinfecção & 640,70 & 768,84 \\
2.6 - Energia Elétrica & 300,00 & 360,00 \\
2.7 - Alimentação c/ Pessoal da Apanha & $-28953,85$ & 15474,79 \\
\hline Fluxo Líquido (A - B) & &
\end{tabular}

* Valores Simulados 


\section{APÊNDICE 2}

QUADRO 2.4 - Fluxo de Caixa do Projeto de Investimento para o Contrato D (valores em R \$ de fevereiro de 1996)

\begin{tabular}{|c|c|c|}
\hline Discriminação & Ano 1 & Ano 15 \\
\hline \multicolumn{3}{|l|}{ A- Entradas } \\
\hline 1 - Entrega do Frangos * & 9104,93 & 9627,19 \\
\hline 2 - Venda da Cama de Frango & 5348,70 & 6418,44 \\
\hline 3 - Fundo Galpão & 1348,20 & 1617,84 \\
\hline 4 - Valor Residual & - & 9275,17 \\
\hline \multicolumn{3}{|l|}{ B-Saídas } \\
\hline 1 - Investimento & 37100,70 & - \\
\hline \multicolumn{3}{|l|}{2 - Custo Operacional } \\
\hline 2.1 - Material para Cama & 1855,95 & 2227,14 \\
\hline 2.2 - Conservação de Equipamentos & 781,08 & 781,08 \\
\hline 2.3 - Conservação do Galpão & 429,60 & 429,66 \\
\hline 2.4 - Mão-de- obra Manejo + Encargos & 3469,40 & 4163,28 \\
\hline 2.5 - Mão-de-obra para Apanha & 553,85 & 664,62 \\
\hline 2.6 - Medicamentos para Desinfecção & 75,00 & 90,00 \\
\hline 2.7 - Gás & 3150,00 & 3780,00 \\
\hline 2.8 - Energia Elétrica & 640,70 & 768,84 \\
\hline 2.9 - Despesa com Associação & 174,85 & 210,88 \\
\hline 2.10 - Alimentação c/ Pessoal da Apanha & 300,00 & 360,00 \\
\hline Fluxo Líquido (A - B) & $-32729,30$ & 13463,14 \\
\hline
\end{tabular}

* Valores Simulados 
APÊNDICE 3

QUADRO 3.1 - ORÇAMENTO - GALPÃO $1.200 \mathrm{~m}^{2}$ TELHA DE BARRO

\section{MATERIAL}

Telha de Barro

Caibros (varas de eucaliptos)

Esteios Pequenos - 4m

Esteios Grande - 8m

Travessa

Escora (mão francesa)

Ripas metros corridos

Linha (eucalipto) metros corridos

Rede Elétrica (dentro do galpão)

Terraplenagem

Material Hidráulico com a Bomba

Mão - de - Obra

Caixa D'água

Caixa para Depósito de água

Poço para abastecimento

Sub-Total
QUANT. V. UNIT. (\$R)

47.000

384

80

80

80

160

12.000

714

68

02
90,00

5,00

5,00

5,00

5,00

5,00

0,30

5,00

30,00

75,00

9,80

9,80

3,80

4,80

58,00

20,00

288,00

1,40

0,85

5,80

75,00
605

650

084

002

042

005

Nebolizador

Telas $\mathrm{m}^{2}$

Cortina $\mathrm{m}^{2}$

Eucatex

Caixas d'água 1.000 litros

Silos de 10 toneladas

Sub-Total
TOTAL (\$R)

$4.230,00$

$1.920,00$ 400,00 400,00 400,00 800,00

$3.600,00$

500,00 800,00

$2.040,00$ 800,00

$2.439,00$ 150,00

$1.100,00$

$1.500,00$

$21.479,00$

Total

$3.430,00$

$1.715,00$

532,00

672,00

$2.436,00$

560,00

$1.440,00$

$1.200,00$

847,00

552,50

487,20

15,00

$1.600,00$

$15.621,70$

$37.100,70$

FONTE: Orçamento elaborado por uma das empresas integradoras. 
APÊNDICE 4

REPRESENTAÇÃO GRÁFICA E EXPRESSÃO GERAL PARA A FUNÇÃO DE DENSIDADE E DISTRIBUIÇÃO DE PROBABILIDADES RETANGULAR 
(A)

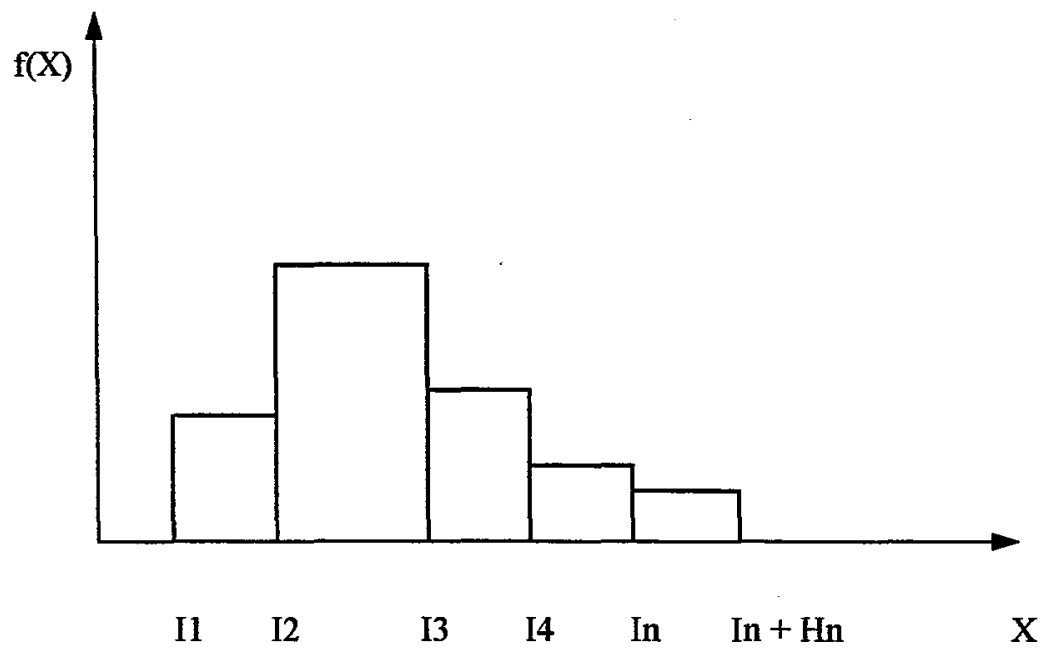

(B)

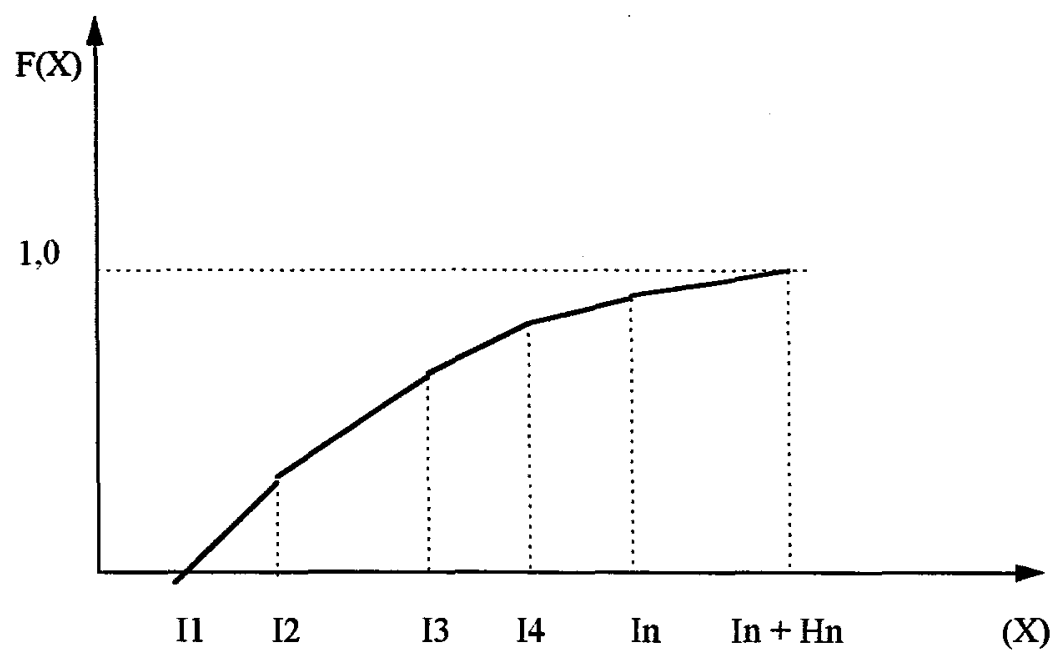

FONTE: SÁ (1985), p.108

FIGURA 5a - (A) Função Densidade de Probabilidade e (B) Função de Distribuição de Probabilidade, Retangular. 


\section{EXPRESSÃO GERAL PARA A FUNÇÃO DE DISTRIBUIÇÃO \\ DE PROBABILIDADE, F(X), RETANGULAR}

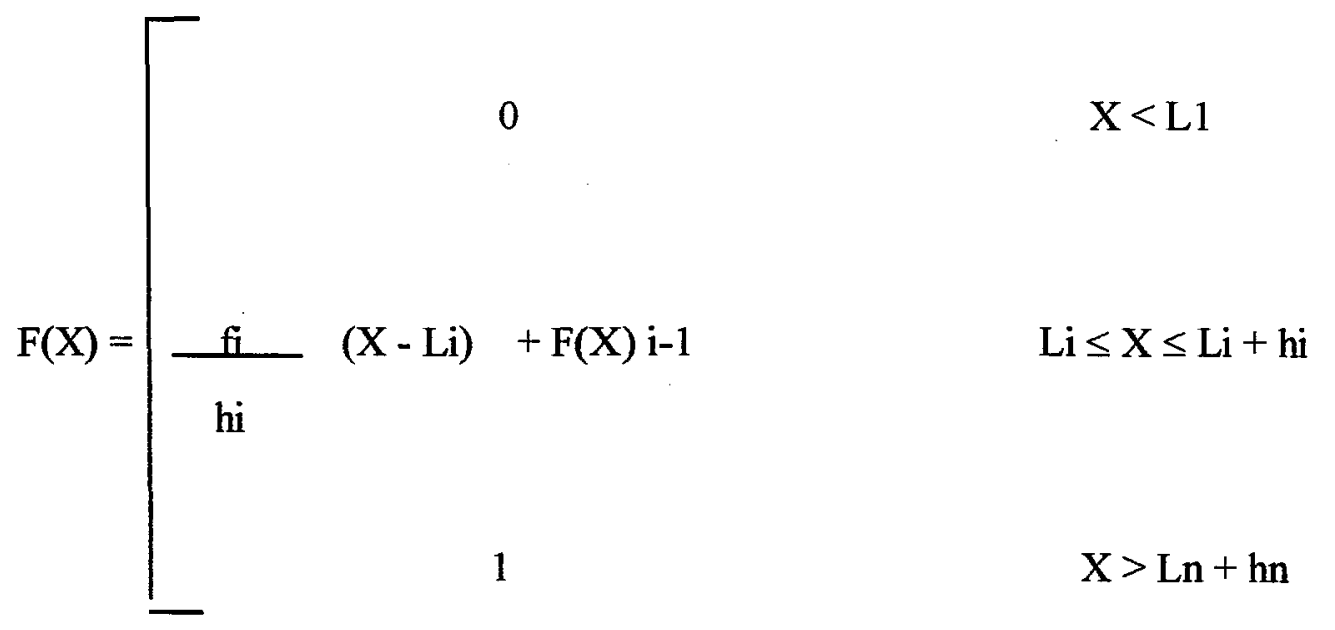

em que,

$\mathrm{fi}=$ frequência relativa simples da $\mathrm{i}$ - ésima classe

$\mathrm{hi}=$ amplitude da $\mathrm{i}-$ ésima classe

$\mathrm{Li}=$ limite inferior da $\mathrm{i}$ - ésima classe

$\mathrm{i}=$ número de classes, sendo $\mathrm{i}=1,2, \ldots \mathrm{n}$

$F(X)$ i- $1=$ frequência relativa acumulada da i-1 classe

FONTE: SÁ (1985), p. 109 


\section{APÊNDICE 5}

RESULTADOS DOS TESTES PARA AVALIAR O FORMATO DA DISTRIBUIÇÃO

DAS VARIÁVEIS A SEREM SIMULADAS 
The SAS system $1 \quad$ 13:32 Wednesday, June 12, 1996

Univariate Procedure

Variable= Peso Médio (PM)

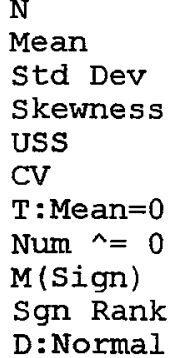

CONTRATO A

\section{Moments}

$\begin{array}{rlr}2477 & \text { Sum Wgts } & 2477 \\ 2.188357 & \text { Sum } & 5422.748 \\ 0.145 & \text { Variance } & 0.02102 \\ 0.168923 & \text { Kurtosis } & 1.133734 \\ 11921.77 & \text { CSS } & 54.86549 \\ 6.800933 & \text { std Mean } & 0.00299 \\ 731.9512 & \text { Pr>|T| } & 0.0001 \\ 2477 & \text { Num }>0 & 2477 \\ 1239 & \text { Pr }>=|\mathrm{M}| & 0.0001 \\ 1535741 & \text { Pr }>=|\mathrm{S}| & 0.0001 \\ 0.017947 & \text { Pr }>\text { D } & 0.0510\end{array}$

The SAS System 2 13:32 Wednesday, June 12, 1996

Univariate Procedure

Variable=Peso Médio (PM)

\begin{tabular}{|c|c|c|c|}
\hline \multicolumn{4}{|c|}{ Quantiles (Def $=5$ ) } \\
\hline 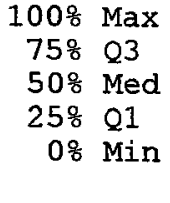 & $\begin{array}{l}3.118 \\
2.283 \\
2.187 \\
2.091 \\
1.535\end{array}$ & $\begin{array}{r}99 \% \\
95 \% \\
90 \% \\
10 \% \\
5 \% \\
1 \%\end{array}$ & $\begin{array}{r}2.556 \\
2.427 \\
2.374 \\
2.009 \\
1.94 \\
1.834\end{array}$ \\
\hline $\begin{array}{l}\text { Range } \\
\text { Q3-Q1 } \\
\text { Mode }\end{array}$ & $\begin{array}{l}1.583 \\
0.192 \\
2.204\end{array}$ & & \\
\hline
\end{tabular}

The SAS System 3 13:32 Wednesday, June 12, 1996

Univariate Procedure

Variable $=$ Peso Médio (PM)

Extremes

\begin{tabular}{lrlr} 
Lowest & Obs & Highest & \multicolumn{1}{c}{ Obs } \\
1.535 & $(1962)$ & 2.672 & $(1960)$ \\
1.721 & $(2057)$ & 2.676 & $(433)$ \\
1.723 & $(1220)$ & 2.737 & $(2108)$ \\
1.744 & $(507)$ & 3.024 & $(2336)$ \\
1.765 & $(405)$ & 3.118 & $(1866)$
\end{tabular}


Variable= Peso Médio (PM)

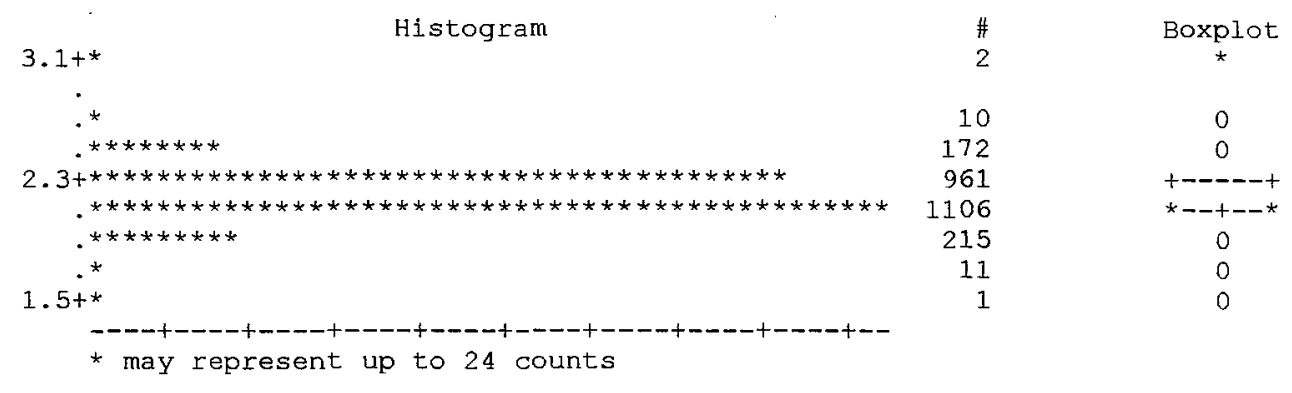

The SAS system 5

13:32 Wednesday, June 12, 1996

Univariate Procedure

Variable= Peso Médio (PM)

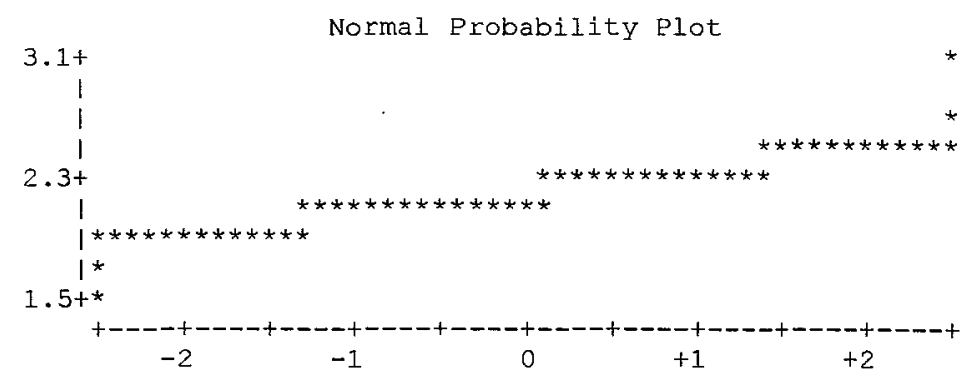

The SAS system 6

13:32 Wednesday, June 12, 1996

Univariate Procedure

\section{Variable= Conversão Alimentar (CA) CONTRATO A}

Moments

$\begin{array}{lrlr}\text { N } & 2477 & \text { Sum Wgts } & 2477 \\ \text { Mean } & 2.047218 & \text { Sum } & 5073.005 \\ \text { Std Dev } & 0.073591 & \text { Variance } & 0.005408 \\ \text { Skewness } & -0.0693 & \text { Kurtosis } & 0.022447 \\ \text { USS } & 10400.11 & \text { CSS } & 14.56836 \\ \text { CV } & 3.746091 & \text { Std Mean } & 0.001541 \\ \text { T:Mean=0 } & 1328.839 & \text { Pr>|T| } & 0.0001 \\ \text { Num N=0 } & 2477 & \text { Num }>0 & 2477 \\ \text { M(Sign) } & 1239 & \text { Pr }>|M| & 0.0001 \\ \text { Sgn Rank } & 1535741 & \text { Pr> }=|S| & 0.0001 \\ \text { D:Normal } & 0.033438 & \text { Pr>D } & <.01\end{array}$

The SAS System 7

13:32 Wednesday, June 12, 1996

Univariate Procedure

Variable= Conversão Alimentar (CA)

Quantiles $(\operatorname{Def}=5)$ 


$\begin{array}{crrr}100 \% \text { Max } & 2.31 & 99 \% & 2.22 \\ 75 \% \text { Q3 } & 2.1 & 95 \% & 2.18 \\ 50 \% \text { Med } & 2.05 & 90 \% & 2.14 \\ 25 \% \text { Q1 } & 2 & 10 \% & 1.95 \\ 0 \% \text { Min } & 1.76 & 5 \% & 1.92 \\ & & 1 \% & 1.87 \\ \text { Range } & 0.55 & & \\ \text { Q3-Q1 } & 0.1 & & \\ \text { Mode } & 2.05 & & \end{array}$

The SAS System 8

13:32 Wednesday, June 12, 1996

Univariate Procedure

Variable $=$ Conversão Alimentar (CA)

\section{Extremes}

$\begin{array}{rrcc}\text { Lowest } & \text { Obs } & \text { Highest } & \text { obs } \\ 1.76 & (203) & 2.27 & (738) \\ 1.81 & (1786) & 2.27 & (1717) \\ 1.82 & (2477) & 2.27 & (1733) \\ 1.82 & (1949) & 2.27 & (1757) \\ 1.82 & (673) & 2.31 & (2158)\end{array}$

The SAS System 9

13:32 Wednesday, June 12, 1996

Univariate Procedure

Variable $=$ Conversão Alimentar (CA)

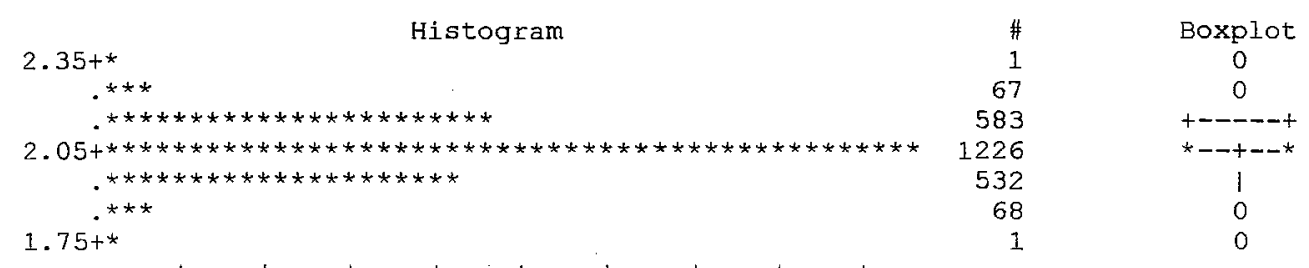

* may represent up to 26 counts

The SAS System $10 \quad 13: 32$ Wednesday, June 12, 1996

Univariate Procedure

Variable $=$ Conversão Alimentar (CA)

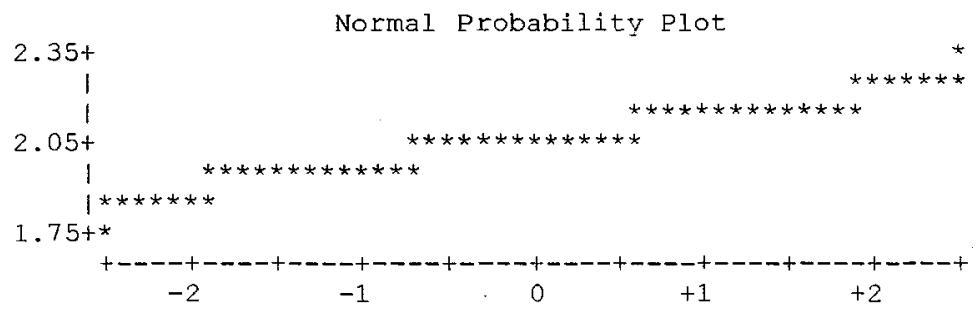


The SAS system $11 \quad 13: 32$ Wednesday, June 12, 1996

Univariate Procedure

variable= Índice de Eficiência e Produtividade (IEP) CONTRATO B

Moments

$\begin{array}{lrlr}\text { N } & 2476 & \text { Sum Wgts } & 2476 \\ \text { Mean } & 224.3867 & \text { Sum } & 556030.2 \\ \text { Std Dev } & 15.92165 & \text { Variance } & 253.7586 \\ \text { Skewness } & -0.18068 & \text { Kurtosis } & 0.001692 \\ \text { USS } & 1.2545 \mathrm{E} 8 & \text { CSS } & 682698.2 \\ \text { CV } & 7.39868 & \text { Std Mean } & 0.333504 \\ \text { T:Mean=0 } & 672.8161 & \text { Pr>|T| } & 0.0001 \\ \text { Num } \wedge=0 & 2476 & \text { Num }>0 & 2476 \\ \text { M(Sign) } & 1239 & \text { Pr }>=|M| & 0.0001 \\ \text { Sgn Rank } & 1535741 & \text { Pr }>=|\mathrm{S}| & 0.0001 \\ \text { D:Normal } & 0.022505 & \text { Pr }>\text { D } & <.01\end{array}$

The SAS System 12

13:32 Wednesday, June 12, 1996

Univariate Procedure

Variable= Índice de Eficiência e Produtividade (IEP)

Quantiles (Def $=5$ )

$\begin{array}{crrr}100 \% \text { Max } & 278.17 & 99 \% & 260.97 \\ 75 \% \text { Q3 } & 235.69 & 95 \% & 250.5 \\ 50 \% \text { Med } & 224.91 & 90 \% & 245.27 \\ 25 \% \text { Q } 1 & 213.86 & 10 \% & 202.45 \\ 0 \% \text { Min } & 167.08 & 5 \% & 195.71 \\ & & 1 \% & 183.53 \\ \text { Range } & 111.09 & & \\ \text { Q3-Q1 } & 21.83 & & \\ \text { Mode } & 208.88 & & \end{array}$

The SAS System 13 13:32 Wednesday, June 12, 1996

Univariate Procedure

Variable= Índice de Eficiência e Produtividade (IEP)

Extremes

$\begin{array}{rrrc}\text { Lowest } & \text { Obs } & \text { Highest } & \text { Obs } \\ 167.08 & (186) & 270.18 & (1666) \\ 171.8 & (518) & 271.65 & (2068) \\ 174.44 & (1392) & 274.56 & (1538) \\ 174.51 & (631) & 274.67 & (2071) \\ 175.29 & (2046) & 278.17 & (2102)\end{array}$


The SAS System 14 13:32 Wednesday, June 12, 1996

Univariate Procedure

Variable= Índice de Eficiência e Produtividade (IEP)
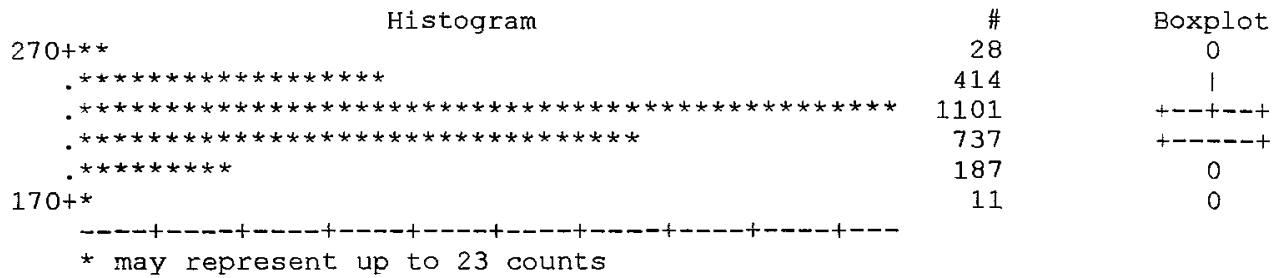

The SAS system 15

13:32 Wednesday, June 12, 1996

Univariate Procedure

Variable= Índice de Eficiência e Produtividade (IEP)

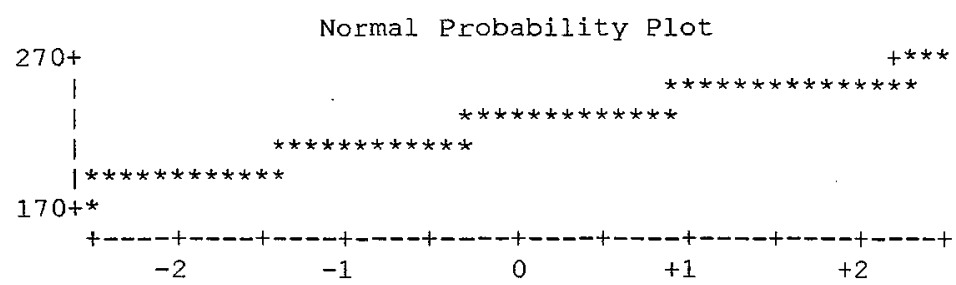

The SAS System 16

13:32 Wednesday, June 12, 1996

Univariate Procedure

\section{Variable= Fator de Produtividade (FP) CONTRATO C}

Moments

$\begin{array}{lrlr}\text { N } & 2476 & \text { Sum Wgts } & 2476 \\ \text { Mean } & 220.5116 & \text { Sum } & 546427.8 \\ \text { Std Dev } & 15.07929 & \text { Variance } & 227.0264 \\ \text { Skewness } & -0.20251 & \text { Kurtosis } & -0.01515 \\ \text { USS } & 1.2116 \mathrm{E} 8 & \text { CSS } & 662910.5 \\ \text { CV } & 7.418788 & \text { Std Mean } & 0.328635 \\ \text { T:Mean=0 } & 670.9925 & \text { Pr>|T| } & 0.0001 \\ \text { Num A=0 } & 2476 & \text { Num }>0 & 2476 \\ \text { M(Sign) } & 1239 & \text { Pr>=|M| } & 0.0001 \\ \text { Sgn Rank } & 1535741 & \text { Pr>=|S| } & 0.0001 \\ \text { D:Normal } & 0.024676 & \text { Pr>D } & <.01\end{array}$

The SAS System 17

13:32 Wednesday, June 12, 1996

Univariate Procedure

Variable= Fator de Produtividade (FP)

Quantiles (Def=5)

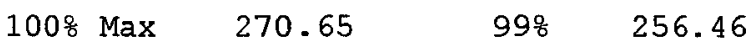




\begin{tabular}{|c|c|c|c|c|}
\hline 75 웅 & Q3 & 231.65 & 95 & 246.12 \\
\hline 50 웅 & Med & 221.165 & 90 웅 & 241.16 \\
\hline $25 \%$ & Q1 & 210.18 & $10 \%$ & 198.78 \\
\hline $0 \%$ & Min & 163.72 & $\begin{array}{l}5 \% \\
1 \%\end{array}$ & $\begin{array}{r}192.11 \\
180.4\end{array}$ \\
\hline $\begin{array}{l}\text { Rang } \\
\text { Q3-Q } \\
\text { Mode }\end{array}$ & & $\begin{array}{r}106.93 \\
21.47 \\
207.19\end{array}$ & & \\
\hline
\end{tabular}

The SAS System 18

13:32 Wednesday, June 12, 1996

Univariate Procedure

Variable= Fator de Produtividade (FP)

Extremes

$\begin{array}{rrcr}\text { Lowest } & \text { Obs } & \text { Highest } & \text { Obs } \\ 163.72 & (186) & 264.28 & (751) \\ 168.35 & (518) & 265.61 & (1666) \\ 170.9 & (1392) & 267.47 & (2068) \\ 170.99 & (631) & 270.07 & (1538) \\ 172.03 & (2046) & 270.65 & (2071)\end{array}$

The SAS System 19

13:32 Wednesday, June 12, 1996

Univariate Procedure

Variable= Fator de Produtividade (FP)
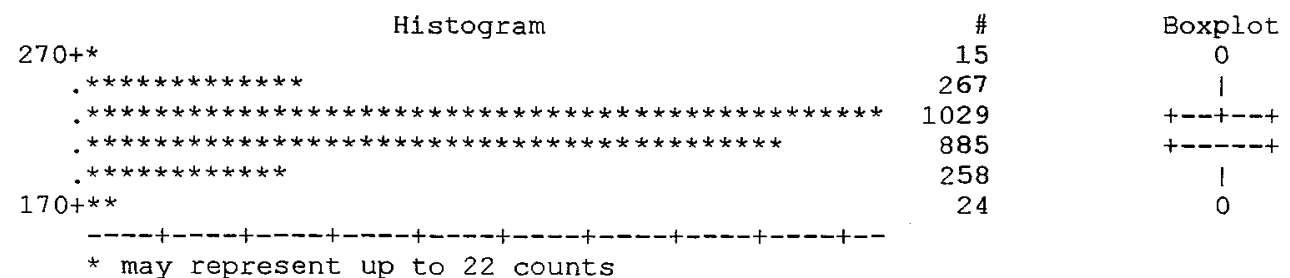

The SAS system 20

13:32 Wednesday, June 12, 1996

Univariate Procedure

Variable= Fator de Produtividade (FP)

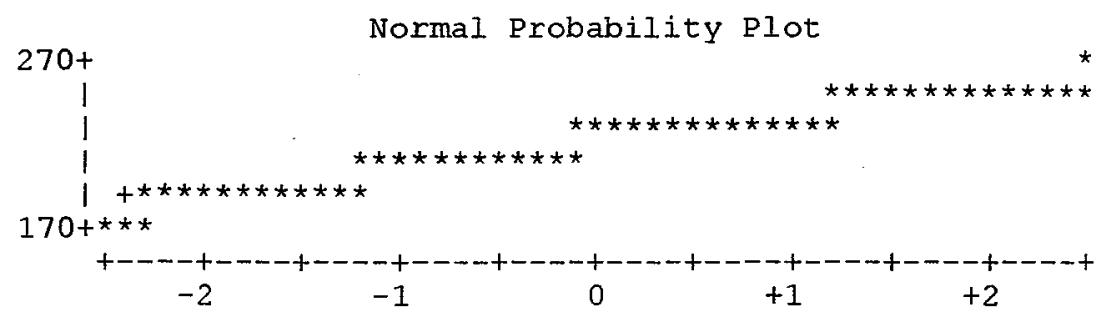


The SAS system 21 13:32 Wednesday, June 12, 1996

Univariate Procedure

Variable = Pontuação (P) CONIRATO D

Moments

$\begin{array}{lrlr}\text { N } & 2476 & \text { Sum Wgts } & 2476 \\ \text { Mean } & 315.7445 & \text { Sum } & 782414.8 \\ \text { Std Dev } & 53.26002 & \text { Variance } & 2836.636 \\ \text { Skewness } & 0.237247 & \text { Kurtosis } & 1.064433 \\ \text { USS } & 2.5469 E 8 & \text { CSS } & 7646291 \\ \text { CV } & 17.59651 & \text { Std Mean } & 1.116122 \\ \text { T:Mean=0 } & 282.8942 & \text { Pr>|T| } & 0.0001 \\ \text { Num } \wedge=0 & 2476 & \text { Num }>0 & 2476 \\ \text { M(Sign) } & 1239 & \text { Pr }>=\mid \text { M| } & 0.0001 \\ \text { Sgn Rank } & 1535741 & \text { Pr>=|S| } & 0.0001 \\ \text { D:Normal } & 0.043375 & \text { Pr }>\text { D } & <.01\end{array}$

The SAS System 22

13:32 Wednesday, June 12, 1996

Univariate Procedure

Variable= Pontuação (P)

\begin{tabular}{crrr}
\multicolumn{5}{c}{ Quantiles } & (Def=5) \\
$100 \%$ Max & 527.77 & $99 \%$ & 469.63 \\
$75 \%$ Q3 & 347.05 & $95 \%$ & 413.65 \\
$50 \%$ Med & 313.715 & $90 \%$ & 383.42 \\
$25 \%$ Q1 & 281.48 & $10 \%$ & 251.83 \\
0\% Min & 87.49 & $5 \%$ & 228.21 \\
& & $1 \%$ & 180.22 \\
Range & 440.28 & & \\
Q3-Q1 & 65.57 & & \\
Mode & 278.86 & &
\end{tabular}

The SAS System 23

Variable=Pontuação
13:32 Wednesday, June 12, 1996

Univariate Procedure

(P)

Extremes

\begin{tabular}{rrrr} 
Lowest & Obs & Highest & \multicolumn{1}{c}{ Obs } \\
87.49 & $(2021)$ & 519.01 & $(1538)$ \\
97.08 & $(2158)$ & 519.52 & $(1312)$ \\
118.21 & $(738)$ & 522.98 & $(237)$ \\
130.47 & $(1285)$ & 527.05 & $(2071)$ \\
138.44 & $(2338)$ & 527.77 & $(954)$
\end{tabular}


The SAS System 24

13:32 Wednesday, June 12, 1996

Univariate Procedure

Variable=Pontuação (P)

\begin{tabular}{|c|c|c|}
\hline Histogram & $\#$ & Boxplot \\
\hline $525+*$ & 10 & 0 \\
\hline.$* *$ & 36 & 0 \\
\hline.$* * * * * *$ & 117 & 0 \\
\hline $375+* * * * * * * * * * * * * * * * * * * * * *$ & 422 & I \\
\hline 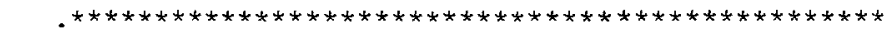 & 950 & +--+--+ \\
\hline$* * * * * * * * * * * * * * * * * * * * * * * * * * * * * * * * * * * *$ & 713 & +-----+ \\
\hline $225+* * * * * * * * * *$ & 183 & I \\
\hline.$* *$ & 40 & 0 \\
\hline.$*$ & 5 & 0 \\
\hline $75+*$ & 2 & 0 \\
\hline
\end{tabular}

The SAS System 25

13:32 Wednesday, June 12, 1996

Univariate Procedure

Variable=Pontuação (P)

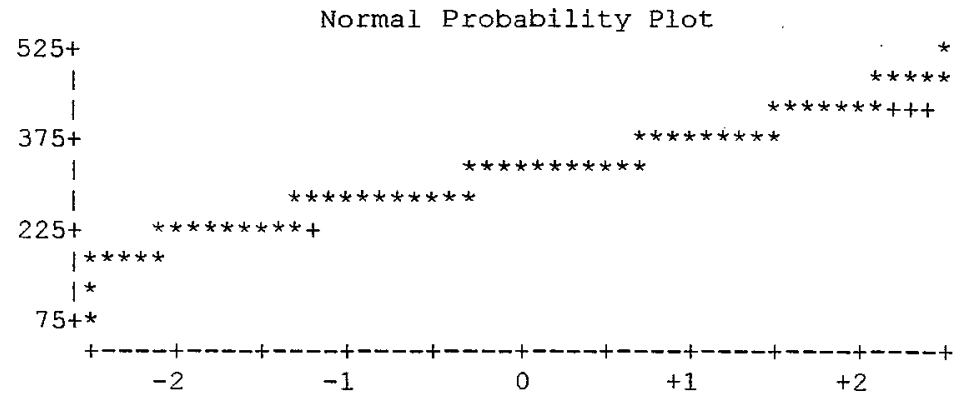


APÊNDICE 6 ANÁLISE DE VARIÂNCIA 
The SAS System I

$\begin{array}{ll}\text { Class } & \text { Levels } \\ \text { PRODUTOR } & 428\end{array}$

PRODUTOR 428

09:36 Wednesday, June 19, 1996

General Linear Models Procedure

Class Level Information

Values

$\begin{array}{llllllllllllllllllllll}1 & 2 & 3 & 4 & 5 & 6 & 7 & 8 & 9 & 10 & 11 & 12 & 13 & 14 & 15 & 16 & 17 & 18 & 19 & 20 & 21 & 22\end{array}$ $\begin{array}{lllllllllllllllllll}23 & 24 & 25 & 26 & 27 & 28 & 29 & 30 & 31 & 32 & 33 & 34 & 35 & 36 & 37 & 38 & 39 & 40 & 41\end{array}$ $\begin{array}{lllllllllllllllllllll}42 & 43 & 44 & 45 & 46 & 47 & 48 & 49 & 50 & 51 & 52 & 53 & 54 & 55 & 56 & 57 & 58 & 59 & 60\end{array}$ $\begin{array}{lllllllllllllllllll}61 & 62 & 63 & 64 & 65 & 66 & 67 & 68 & 69 & 70 & 71 & 72 & 73 & 74 & 75 & 76 & 77 & 78 & 79\end{array}$ $\begin{array}{lllllllllllllllllll}80 & 81 & 82 & 83 & 84 & 85 & 86 & 87 & 88 & 89 & 90 & 91 & 92 & 93 & 94 & 95 & 96 & 97 & 98\end{array}$ $\begin{array}{llllllllllllll}99 & 100 & 101 & 102 & 103 & 104 & 105 & 106 & 107 & 108 & 109 & 110 & 111 & 112\end{array}$

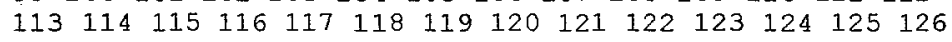
$\begin{array}{llllllllllllll}127 & 128 & 129 & 130 & 131 & 132 & 133 & 134 & 135 & 136 & 137 & 138 & 139 & 140\end{array}$ $\begin{array}{llllllllllllll}141 & 142 & 143 & 144 & 145 & 146 & 147 & 148 & 149 & 150 & 151 & 152 & 153 & 154\end{array}$ $\begin{array}{lllllllllllllll}155 & 156 & 157 & 158 & 159 & 160 & 161 & 162 & 163 & 164 & 165 & 166 & 167 & 168\end{array}$ $\begin{array}{llllllllllllll}169 & 170 & 171 & 172 & 173 & 174 & 175 & 176 & 177 & 178 & 179 & 180 & 181 & 182\end{array}$ $\begin{array}{llllllllllllll}183 & 184 & 185 & 186 & 187 & 188 & 189 & 190 & 191 & 192 & 193 & 194 & 195 & 196\end{array}$ $\begin{array}{llllllllllllll}197 & 198 & 199 & 200 & 201 & 202 & 203 & 204 & 205 & 206 & 207 & 208 & 209 & 210\end{array}$ $\begin{array}{llllllllllllll}211 & 212 & 213 & 214 & 215 & 216 & 217 & 218 & 219 & 220 & 221 & 222 & 223 & 224\end{array}$ $\begin{array}{llllllllllllll}225 & 226 & 227 & 228 & 229 & 230 & 231 & 232 & 233 & 234 & 235 & 236 & 237 & 238\end{array}$ $\begin{array}{llllllllllllll}239 & 240 & 241 & 242 & 243 & 244 & 245 & 246 & 247 & 248 & 249 & 250 & 251 & 252\end{array}$ $\begin{array}{llllllllllllll}253 & 254 & 255 & 256 & 257 & 258 & 259 & 260 & 261 & 262 & 263 & 264 & 265 & 266\end{array}$ $\begin{array}{lllllllllllllll}267 & 268 & 269 & 270 & 271 & 272 & 273 & 274 & 275 & 276 & 277 & 278 & 279 & 280\end{array}$ $\begin{array}{llllllllllllll}281 & 282 & 283 & 284 & 285 & 286 & 287 & 288 & 289 & 290 & 291 & 292 & 293 & 294\end{array}$ $\begin{array}{llllllllllllll}295 & 296 & 297 & 298 & 299 & 300 & 301 & 302 & 303 & 304 & 305 & 306 & 307 & 308\end{array}$ $\begin{array}{llllllllllllll}309 & 310 & 311 & 312 & 313 & 314 & 315 & 316 & 317 & 318 & 319 & 320 & 321 & 322\end{array}$ $\begin{array}{llllllllllllll}323 & 324 & 325 & 326 & 327 & 328 & 329 & 330 & 331 & 332 & 333 & 334 & 335 & 336\end{array}$ $\begin{array}{llllllllllllll}337 & 338 & 339 & 340 & 341 & 342 & 343 & 344 & 345 & 346 & 347 & 348 & 349 & 350\end{array}$ $\begin{array}{llllllllllllll}351 & 352 & 353 & 354 & 355 & 356 & 357 & 358 & 359 & 360 & 361 & 362 & 363 & 364\end{array}$ $\begin{array}{llllllllllllll}365 & 366 & 367 & 368 & 369 & 370 & 371 & 372 & 373 & 374 & 375 & 376 & 377 & 378\end{array}$ $\begin{array}{llllllllllllll}379 & 380 & 381 & 382 & 383 & 384 & 385 & 386 & 387 & 388 & 389 & 390 & 391 & 392\end{array}$ $\begin{array}{llllllllllllll}393 & 394 & 395 & 396 & 397 & 398 & 399 & 400 & 401 & 402 & 403 & 404 & 405 & 406\end{array}$ $\begin{array}{llllllllllllll}407 & 408 & 409 & 410 & 411 & 412 & 413 & 414 & 415 & 416 & 417 & 418 & 419 & 420\end{array}$ $\begin{array}{llllllll}421 & 422 & 423 & 424 & 425 & 426 & 427 & 428\end{array}$

Number of observations in data set $=2478$

The SAS System 2 09:36 Wednesday, June 19, 1996

General Linear Models procedure

Dependent Variable: Peso Médio (PM) CONTRATO A

$\begin{array}{lrrrrr}\text { Source } & \text { DF } & \begin{array}{r}\text { Sum of } \\ \text { Squares }\end{array} & \begin{array}{r}\text { Mean } \\ \text { Square }\end{array} & \text { F Value } & \text { Pr }>\text { F } \\ \text { Model } & 427 & 11.61639954 & 0.02720468 & 1.29 & 0.0002 \\ \text { Error } & 2050 & 43.13659574 & 0.02104224 & & \\ \text { Corrected Total } & 2477 & 54.75299528 & & \text { PM Mean } \\ & \text { R-Square } & \mathrm{C.V} . & \text { Root MSE } & \\ & 0.212160 & 6.628286 & 0.145059 & 2.188491\end{array}$

The SAS System 3

09:36 Wednesday, June 19, 1996

General Linear Models Procedure

Dependent Variable: Peso Médio (PM)

$\begin{array}{lrrrrr}\text { Source } & \text { DE } & \text { Type I SS } & \text { Mean Square } & \text { F Value } & \text { Pr }>\text { F } \\ \text { PRODUT } & 427 & 11.61639954 & 0.02720468 & 1.29 & 0.0002 \\ \text { Source } & \text { DF } & \text { Type II SS } & \text { Mean Square } & \text { F Value } & \text { Pr }>\text { F }\end{array}$




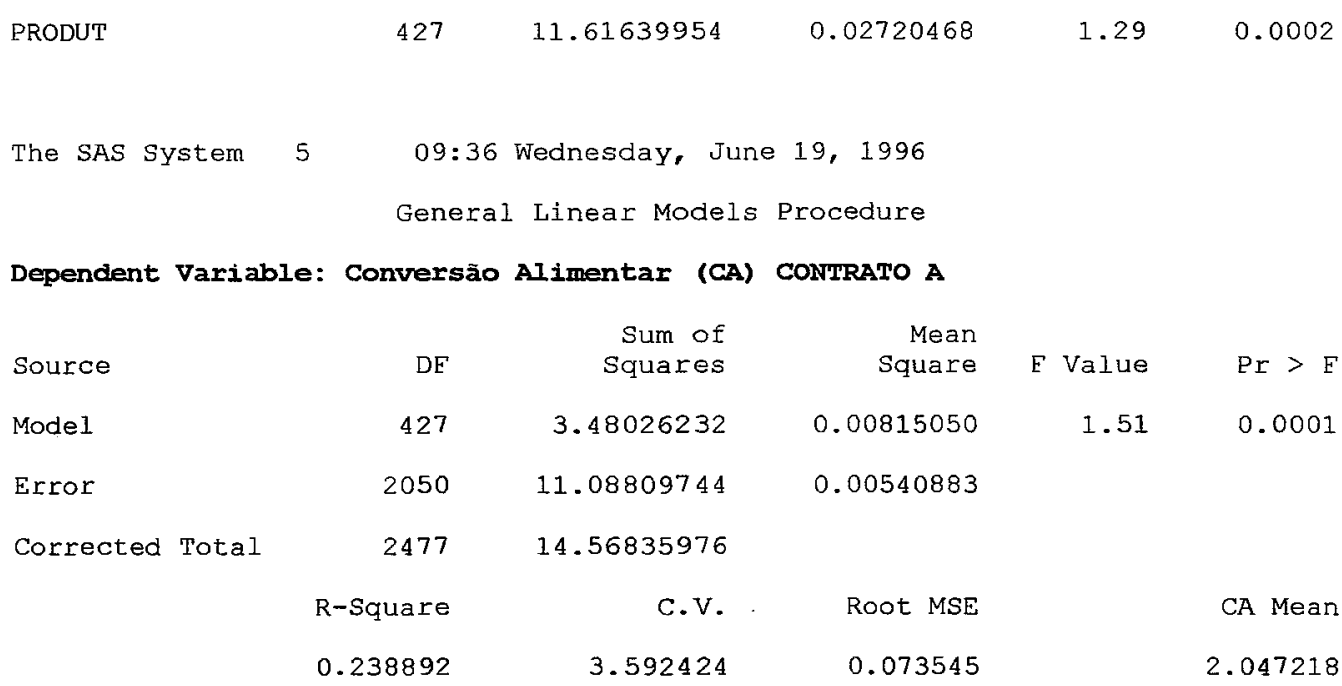

The SAS System $6 \quad$ 09:36 Wednesday, June 19, 1996

General Linear Models Procedure

Dependent Variable: conversão Alimentar (CA)

$\begin{array}{lrrrrr}\text { Source } & \text { DF } & \text { Type I SS } & \text { Mean Square } & \text { E Value } & \text { Pr }>E \\ \text { RRODUT } & 427 & 3.48026232 & 0.00815050 & 1.51 & 0.0001 \\ \text { Source } & \text { DF } & \text { Type II SS } & \text { Mean Square } & \text { F Value } & \operatorname{Pr}>E \\ \text { PRODUT } & 427 & 3.48026232 & 0.00815050 & 1.51 & 0.0001\end{array}$

The SAS System $8 \quad 09: 36$ Wednesday, June 19, 1996

General Linear Models Procedure

NOTE: Due to missing values, only 2477 observations can be used in this analysis.

The SAS System $909: 36$ Wednesday, June 19, 1996

General Linear Models Procedure

Dependent Variable: Indide de Eficiencia e produtividade (IEP) CONTRATO B

$\begin{array}{lrrrrr}\text { Source } & \text { DF } & \begin{array}{r}\text { Sum of } \\ \text { Squares }\end{array} & \begin{array}{r}\text { Mean } \\ \text { Square }\end{array} & \text { F Value } & \text { Pr }>F \\ \text { Model } & 427 & 159852.9748 & 374.3629 & 1.48 & 0.0001 \\ \text { Error } & 2049 & 519951.4027 & 253.7586 & & \\ \text { Corrected Total } & 2476 & 679804.3775 & & \\ & \text { R-Square } & \text { C.V. } & \text { Root MSE } & \text { IEP Mean } \\ & 0.235146 & 7.099950 & 16.62980 & 224.3650\end{array}$

The SAS System 10 09:36 Wednesday, June 19, 1996

General Linear Models Procedure

Dependent Variable: Indice de Eficência e Produtividade (IEP) 


$\begin{array}{lrrrrr}\text { Source } & \text { DE } & \text { Type I SS } & \text { Mean Square } & \text { E Value } & \text { Pr }>\text { F } \\ \text { PRODUT } & 427 & 159852.9748 & 374.3629 & 1.48 & 0.0001 \\ \text { Source } & \text { DF } & \text { Type II SS } & \text { Mean Square } & \text { F Value } & \text { Pr }>\text { F } \\ \text { PRODUT } & 427 & 159852.9748 & 374.3629 & 1.48 & 0.0001\end{array}$

General Linear Models Procedure

NOTE: Due to missing values, only 2477 observations can be used in this analysis.

The SAS System 13 09:36 Wednesday, June 19, 1996

General Linear Models Procedure

Dependent Variable: Fator de Produtividade (FP) CONTRATO C

$\begin{array}{lrrrrr}\text { Source } & \text { DE } & \begin{array}{r}\text { Sum of } \\ \text { Squares }\end{array} & \begin{array}{r}\text { Mean } \\ \text { Square }\end{array} & \text { F Value } & \text { Pr }>\text { F } \\ \text { Model } & 427 & 142930.3294 & 334.7315 & 1.47 & 0.0001 \\ \text { Error } & 2049 & 465183.3978 & 227.0295 & & \\ \text { Corrected Total } & 2476 & 608113.7272 & & \text { FP Mean } \\ & \text { R-Square } & \mathrm{C.V} . & \text { Root MSE } & & \\ & 0.235039 & 6.835101 & 15.6750 & 220.4429\end{array}$

The SAS System $14 \quad 09: 36$ Wednesday, June 19, 1996

General Iinear Models Procedure

Dependent Variable: Fator de Produtividade (FP)

$\begin{array}{lrrrrr}\text { Source } & \text { DF } & \text { Type I SS } & \text { Mean Square } & \text { F Value } & \operatorname{Pr}>F \\ \text { PRODUT } & 427 & 142930.3294 & 334.7315 & 1.47 & 0.0001 \\ \text { Source } & \text { DF } & \text { Type II SS } & \text { Mean Square } & \text { F Value } & \operatorname{Pr}>E \\ \text { PRODUT } & 427 & 142930.3294 & 334.7315 & 1.47 & 0.0001\end{array}$

General Linear Models Procedure

NOTE: Due to missing values, only 2477 observations can be used in this analysis.

The SAS System $17 \quad 09: 36$ Wednesday, June 19, 1996

General Linear Models Procedure

Dependent Variable: Pontuação (P) CONTRATo D

$\begin{array}{lrrrrr}\text { Source } & \text { DF } & \begin{array}{r}\text { Sum of } \\ \text { Squares }\end{array} & \begin{array}{r}\text { Mean } \\ \text { Square }\end{array} & \text { F Value } & \text { Pr }>\text { F } \\ \text { Model } & 427 & 1789059.315 & 4189.834 & 1.48 & 0.0001 \\ \text { Error } & 2049 & 5812258.556 & 2836.632 & & \\ \text { Corrected Total } & 2476 & 7601317.871 & & \text { P Mean } \\ & \text { R-Square } & \text { C.V. } & \text { Root MSE } & 315.6589\end{array}$

The SAS System 18 09:36 Wednesday, June 19, 1996 
General Linear Models Procedure

Dependent Variable: Pontuação (P)

$\begin{array}{lcrrrrr}\text { Source } & \text { DF } & \text { Type I SS } & \text { Mean Square } & F \text { Value } & \text { Pr }>\text { F } \\ \text { PRODUT } & 427 & 1789059.315 & 4189.834 & 1.48 & 0.0001 \\ \text { Source } & \text { DF } & \text { Type II SS } & \text { Mean Square } & \text { F VaIue } & \text { Pr }>\text { F } \\ \text { PRODUT } & 427 & 1789059.315 & 4189.834 & 1.48 & 0.0001\end{array}$

